\title{
A CONSERVATION PLAN FOR RESERVOIR CANYON NATURAL RESERVE, SAN LUIS OBISPO, CA
}

\author{
A Thesis Project \\ Presented to \\ The Faculty of \\ California Polytechnic State University, \\ San Luis Obispo
}

\author{
In Partial Fulfillment \\ Of the Requirements for the Degree \\ Master of City and Regional Planning
}

by

Brian M. Provenzale

June 2012 
(C) 2012

Brian M. Provenzale ALL RIGHTS RESERVED 


\title{
COMMITTEE MEMBERSHIP
}

TITLE:

A CONSERVATION PLAN FOR RESERVOIR CANYON NATURAL RESERVE, SAN LUIS OBISPO, CA

\author{
AUTHOR: $\quad$ Brian M. Provenzale
}

DATE SUBMITTED: June 2012

COMMITTEE CHAIR: Adrienne Greve, Assistant Professor

COMMITTEE MEMBER: Chris W. Clark, Lecturer

COMMITTEE MEMBER: Freddy Otte, City Biologist, San Luis Obispo, Calif. 


\author{
ABSTRACT \\ A Conservation Plan for Reservoir Canyon Natural Reserve, \\ San Luis Obispo, CA \\ Brian M. Provenzale
}

My thesis project is to create a conservation plan for the Reservoir Canyon Natural Reserve (RCNR) in San Luis Obispo, California. It is a professional project for the City of San Luis Obispo with the goal of eventual adoption by the City Council. The plan was motivated by City policy, which advises creating conservation plans for open spaces, and by a particular need to address management issues in RCNR that include plant and wildlife conservation, trail access, erosion, electrical utility easements, and other legal matters. The project consists of two main components: the conservation plan and a companion paper. The paper is an overview of the theory and best practices involved in conservation planning, and is meant to be complementary to the conservation plan. Therefore, discussions found in the paper are not present in the plan itself, but instead serve as background. The paper consists primarily of a literature review and my reflections on how the literature applies to the process of planning and managing RCNR. The Draft Reservoir Canyon Natural Reserve Conservation Plan, attached as an appendix, explains the conditions of the reserve, and describes the goals and management strategies the City will employ. 


\section{ACKNOWLEDGMENTS}

Thanks go to my project committee, Adrienne Greve (chair), Chris Clark, and Freddy Otte for their feedback and guidance. I would especially like to thank Freddy for his patient and thorough supervision in the conservation planning process, and for introducing me to electro-fishing.

Additional thanks go to all of the City of San Luis Obispo staff: Natural Resources manager Neil Havlik for his wisdom and for providing the historical and legal background for the plan; and the GIS, utilities, and park rangers staff who contributed maps and information to the plan.

Finally, thanks to my wife, Lisa Lindert, for her unwavering support of all my academic endeavors. 


\section{TABLE OF CONTENTS}

\section{CHAPTER}

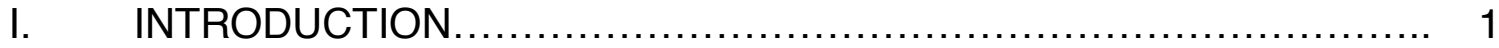

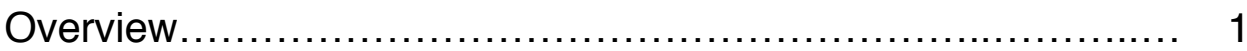

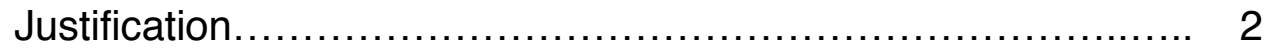

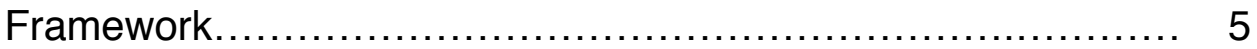

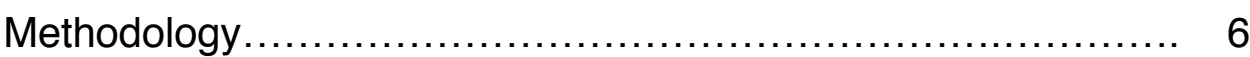

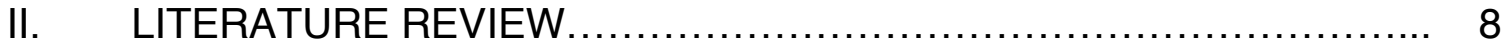

Reasons for Conservation $\ldots \ldots \ldots \ldots \ldots \ldots \ldots \ldots \ldots \ldots \ldots \ldots \ldots, 8$

Theories on the Practice of Conservation Management......... 11

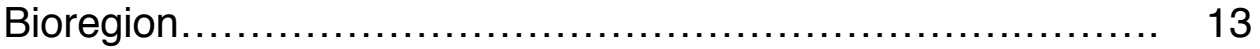

Wildfire Protection........................................ 14

Trail Management......................................... 16

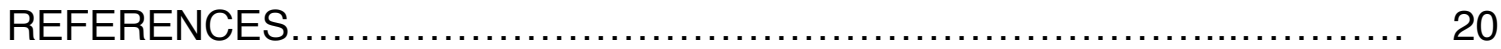

\section{APPENDIX:}

Reservoir Canyon Natural Reserve

Conservation Plan (Project Draft). 


\section{Introduction}

\section{Overview}

This project is to create a conservation plan for the Reservoir Canyon Natural Reserve (RCNR) in San Luis Obispo, California. RCNR is the City's only major open space area without a conservation plan. For that reason, and to both protect the property's natural habitats and biodiversity, a plan is needed. The City also identified an electric utility maintenance easement, a trail access easement, and the need for wildfire preparedness as central issues the plan should address.

The City of San Luis Obispo is located along Highway 101, midway between San Francisco and Los Angeles. Among the most notable physical features is the largely undeveloped mountainous terrain that surrounds the city, which offers residents and visitors scenic vistas and supports local flora and fauna. Recognizing these assets, the City sees the need to protect them and therefore sets the following goals in the Conservation and Open Space Element (COSE) of its general plan:

- "7.2: The City will maintain and enhance conditions necessary to enable a species to become self-sustaining." (p. 6.36).

- "7.4: Protect, preserve and create the conditions that will promote the preservation of significant trees and other vegetation, particularly native California species" (p. 6.40).

- "8.1: Secure and maintain a healthy and attractive Greenbelt around the urban area, comprised of diverse and connected natural habitats, and productive agricultural land that reflects the City's watershed and topographic boundaries" (p. 6.46) 
Within this Greenbelt is the Reservoir Canyon Natural Reserve property, which is the subject of this project.

Reservoir Canyon is a natural reserve on nearly 700 acres owned and maintained by the City of San Luis Obispo. Located in the hills northeast of the city, the land includes a perennial stream, a remnant of the water collection system built in the 1800 s by private water company. Once the city secured a more reliable water supply near Santa Margarita in the 1950s, the system ceased operation, and eventually the land became a natural reserve and open space for public recreation (City of SLO, n.d.). The hiking trail spans over 2.5 miles and features an elevation change from 400 to 1,715 feet above sea level (City of SLO, 2011b). The trail connects Reservoir Canyon to the adjacent Bowden Ranch, which lies on 207 acres directly west of Reservoir Canyon. The steep 0.9 mile Bowden Ranch trail begins at the eastern endpoint of Lizzie Street in town and reaches a peak of 1,520 feet (City of SLO, 2011a).

\section{Justification}

Currently, no conservation management plans exists for the Reservoir Canyon Natural Reserve. However it is the implementation policy (program 8.7.1.E) of the Conservation and Open Space element that the city will: "Manage its open space holdings and enforce its open space easements, consistent with General Plan goals and policies and the Open Space Ordinance“ (p. 6.56). The element further specifies in Appendix C ("Management of Open Space Lands"): 
"The City will adopt conservation plans (or master plans with conservation components) for large parcels, and for small parcels where conservation challenges and solutions need to be clarified. The preparation and adoption process shall foster participation by resource-protection experts and by the public... The City's Lopez Canyon property (outside the planning area) and Reservoir Canyon property will be managed as open space" (p. 6.77).

Additionally, in its role "(a)s a steward for the natural resources of future generations, the City must preserve habitat and the species that it supports" (City of SLO, 2006, p.36). Therefore, since Reservoir Canyon Natural Reserve is considered an open space, the client, San Luis Obispo, has decided to create a conservation plan. The City specified that the plan must adhere to the Conservation Guidelines for Open Space Lands of the City of San Luis Obispo, and it should also be based upon information obtained from direct observation, biologist reports, public feedback, and additional background information provided by the city.

The essential relevance of this project to planning is that its end product will result in a plan document intended for adoption by the San Luis Obispo city council. The plan will guide the city in the most appropriate uses and maintenance of the land with the foremost goal being to preserve natural habitats and maintain biodiversity. As a document, the plan's functional purpose is ((City of SLO, 2002, p.21):

1) To provide an account of the prevailing condition of a property.

2) To set out future goals for the property.

3) To prescribe a means of achieving those goals. 
Specific characteristics of the area justify the need for the guidance a plan would provide. These characteristics include: the fact that the land is a watershed; the presence of serpentine rock (which supports rare plant species); and the dual uses of the area as an ecological preserve and a recreation space.

The need for a conservation plan also centers on the following three specific objectives as identified by the city's Natural Resources Program.

\section{Objective 1 - Manage the PG\&E utility maintenance easement.}

The first relates to an electrical tower replacement project PG\&E began in 2011. San Luis Obispo would prefer to have a conservation plan in place to help minimize disturbance to the ecosystem as the project progresses and in advance of future tower maintenance activities. This would be accomplished in part by implementing an ongoing monitoring program.

\section{Objective 2 - Create a wildfire preparedness plan.}

The second objective is to identify wildfire threats and include a preparedness plan. Developed land abuts the western front of the Bowden Ranch space, meaning the issues of a wildland-urban interface (WUI) management must be considered in developing a wildfire prevention and response plan.

\section{Objective 3 - Manage existing legal agreements neighboring private landowners.}

The third objective is to manage legal issues. One is the easement the City owns on the southeastern portion of the Reservoir Canyon. The RCNR trail 
cuts through privately owned property, and trespassing sometimes occurs when hikers leave the trail. Therefore, the City would like to manage the trail easement in a way that minimizes disruption to the landowner.

A second agreement, with a separate neighboring landowner on the northeast side of Reservoir Canyon, allows watering for up to 40 head of livestock - in this case, cattle. The City would therefore like to mitigate any damage the cattle may cause to RCNR.

\section{Framework}

As stated in the Conservation and Open Space Element, San Luis Obispo considers itself a steward of the natural resources of future generations. Therefore, this project examines theories of conservation planning with respect to stewardship and applies this knowledge to the development of management practices that will be specified in the conservation plan. This examination of stewardship includes exploration of environmental resilience theory to help further define optimal conservation management strategies, particularly with regard to mitigating risks from wildfire and climate change.

Applying the theory required filtering it first through the reality of conditions in San Luis Obispo. Specifically, considerations for how best to apply theory must be made against the background of factors such as: established city goals, policies, and procedures; regulations from city ordinances; biological inventory data; and stakeholder feedback. Therefore, analysis of these factors will be 
necessary to check for consistency with each other and for sufficiency in covering city's goals and policies.

\section{Methodology}

The method for compiling the Reservoir Canyon Natural Reserve Conservation Plan consisted of the following activities.

1. Literature review: Analysis of theory and best practices for conservation management

2. Compilation of inventory data from:

- Biologists' reports: A 2002 botanical survey from a Cal Poly student project was used as a preliminary plant species inventory in the plan. Also, a biological consulting firm was contracted and instructed by the City's Natural Resources Program to take a wildlife survey and species inventory of the project area. [The data from the survey has not yet been made available by the consultants and therefore is not included in the draft plan. As a result, the plan also does not refer to management with respect to particular animal species.]

- Environmental impact reports from local projects that had cataloged species and environmental issues, which are likely to be relevant to management of the project site

- GIS maps and data from the city: biological data; trails; fire safety zones; and others that may be identified by stakeholders

- Existing conservation plans for other open spaces in San Luis Obispo

- Personal observation: Site visits to gain a broad overview of the land and its uses as a background for analysis of the above data, and to determine optimal locations for photographic monitoring.

3. Consultation with city staff to identify government stakeholder concerns and objectives: 
- Regular meetings with the city biologist and the Natural Resources manager to discuss RCNR policies. Preparation for these meetings included analysis of goals, policies, programs, ordinances, and guidelines from various City documents.

- Meetings with additional city government stakeholders as identified by the above.

4. Public outreach: As part of the formal adoption process for the plan, the city held a meeting to inform the public about the planning process and to learn about their desires and concerns for Reservoir Canyon Natural Reserve.

5. Design and compilation: Create the plan using the city's specific Conservation Guidelines for Open Space Lands, combined with the information gathered from the previous phases. The project draft plan is included as the Appendix. 


\section{Literature Review}

The following literature review provides a theoretical background for the Reservoir Canyon Natural Reserve Conservation Plan. The plan's policies were considered in light of the topics briefly discussed below, beginning with the high theory rationale for conservation itself and ending in the more pragmatic realms of wildfire protection and trail management.

\section{Reasons for Conservation}

San Luis Obispo's goal of environmental stewardship echoes the tradition and theory of conservation. Cole and Yung (2010, p.1) observe that people appear to share the common belief that parks and wilderness are places set aside and protected from development for their beauty and for the enjoyment of future generations, representing "powerful symbols" and "sparking imagination." However, they argue that twentieth century conservation goals were centered on "naturalness" of the sort previously mentioned, but no longer suffice for the current era of climate change and anthropogenic stressors (p.2).

The broad justification of current ecological conservation is preserving biological diversity. Ryan explains: "Biodiversity is commonly analyzed at three levels: the variety of ecosystems within which organisms live and evolve, the variety of species, and the genetic variety within those species themselves" (1992, p.7). Biodiversity has value for scientific study, for beauty, and for the 
mutual preservation of humans and all other species, which are interdependent (Ryan, 1992,).

A deeper explanation of this last point comes from Maser (1999, p. 232): "Each ecosystem contains redundancies, which... give an ecosystem the resilience either to resist change or to bounce back after disturbance." Biodiversity is an "environmental insurance policy" (p. 232) built on three forms of diversity - structure, composition, and function-which parallel the three levels expressed by Ryan-ecosystem variety, species variety, and genetic variety of species. Maser advocates "long-term ecological wholeness and biological richness" as measures of economic health and the land's ability to provide for human needs (p. 233). The resource inventory required by San Luis Obispo for the Reservoir Canyon Conservation Plan is therefore an important aspect of the planning process that fits in with Maser's theory of maintaining biodiversity.

The provision for human needs mentioned by Maser directly relates to ecosystem services, which is another justification for conservation. Examples of ecosystem services include water purification, maintenance of soil productivity, carbon sequestration, flood control, pollination, and recreational opportunities. The challenge is in valuation of these services due to the complexity ecosystems and the variety of services provided (Siikamaki and Chow, 2008). Whatever the difficulty, though, it is important that the Reservoir Canyon Conservation Plan at least acknowledges the importance of ecosystems services. 
There is also an ethical component in justifying conservation, which is implied in Cole and Young's mention of stewardship: “(T)he key challenge to park and wilderness stewardship is to decide where, when, and how to intervene in physical and biological processes to conserve what we value in these places" (2010, p. 7). Stewardship is a frequently used word in conjunction with conservation and is one example of the ethical justification for conservation. The EPA issued a report in 2005 explaining environmental stewardship as "the responsibility for environmental quality shared by all those whose actions affect the environment." In the context of land and ecosystems this means supporting ecologically sensitive land management and development, and protecting and restoring ecosystems functions, goods, and services. A conservation plan should therefore account for this balance of land uses.

Notable conservationist Aldo Leopold developed a "land ethic," which is summed up in this quotation: "A thing is right when it tends to preserve the integrity, stability, and beauty of the biotic community. It is wrong when it tends otherwise" (Leopold, 1987). The ethic expresses a holistic view of stewardship where the idea of the "community" in which people live is expanded to include soil, water, plants, and animals: "In short, a land ethic changes the role of Homo sapiens from conqueror of the land-community to plain member and citizen of it. It implies respect for his fellow-members, and also respect for the community as such." Like the EPA statement, Leopold's land ethic implies a requirement to balance human needs with those of the ecosystem. However, Leopold seems to 
suggest that humans should strive for a harmonious existence with nature rather than make the value judgments advised by Cole and Young. In that respect, Leopold's land ethic is perhaps idealistic, while the cognizant process "to decide where, when, and how to intervene" suggested by Cole and Young is clearly more practical, particularly in the context of conservation planning for an open space reserve adjacent to urban land use like Reservoir Canyon.

\section{Theories on the Practice of Conservation Management}

Whatever the mandate or motivation for conservation, the next step is setting policies and objectives for day-to-day and long-term management. First, regarding the scope of management, Barborak (1995, pp. 35-37) suggests that local governments' role in conservation tends to be limited to "managing small areas of local importance for recreation (or) watershed protection." However, he notes that the trend is for municipalities' influence in the arena of protected land management to grow, which implies "bioregional thinking" to manage land in the context of a network of conservation areas owned by various groups. The City of San Luis Obispo's surrounding green belt of opens spaces is an example of such a network. By following the same framework as the City's other open space plans, the Reservoir Canyon Natural Reserve (RCNR) Conservation Plan forms a link within the network.

Groves (2008, p. 261-262) offers a set of criteria to help determine planning priorities in conservation areas, including: 
- Some measure of the value of biodiversity or conservation in the area

- Threats to the area

- The number of rare or endangered species in the area

- The quality or ecological condition of the area

Groves considers biodiversity value and threats the most important of these and further suggests qualitative ratings to rank these aspects. Threats, for example, may be further subdivided into categories like severity, scope, immediacy, and irreversibility, and each specific threat within those categories may be given ratings ("low," "medium," "high," or "very high").

Opportunities may also be identified in the plan priorities. One example is providing for mitigation offsets for development in other areas. The results of Underwood's (2011) study of San Diego County show the importance of having a landscape-level conservation plan in place to guide development mitigation and conservation acquisitions. This is applicable to site-level conservation plans in that a strategy may be written to identify mitigation fees as a funding source for ongoing maintenance and monitoring, or for restoration of damaged habitats. However, Underwood notes that implementing such a strategy may be a challenge if citywide mitigation programs do not ensure consistency by identifying offset opportunities.

Many other challenges exist in conservation planning, but among the newest is accounting for the effects of climate change. Higgs and Hobbs (2010) see the valuation of ecosystem services as potentially problematic when it comes 
to climate change and conservation. They believe the key is finding the right balance between precaution and action, but that assigning market values to ecosystem services may lead to haphazard or ad hoc intervention in certain ecosystems. Holling (2009) echoes the need to consider climate adaptation. He notes that (a) qualitative (i.e. systematic) change is likely, (b) that such change may become increasingly irreversible, and (c) with the decreased likelihood of reversibility, more emphasis is likely to be placed on adaptation.

\section{Bioregion}

Climate adaptation and fire mitigation depend on the biological setting, in this case, the Central Coast Bioregion. The vegetation in San Luis Obispo, and the Reservoir Canyon area in particular is a mixture of primarily chaparral, coastal sage scrub, and annual grassland. Of particular note for this project are the serpentine grassland and coastal sage scrub habitats. Most of the RCNR property is on serpentinitic soil, which is weathered from ultramafic serpentine minerals. Calcium and magnesium co-vary in soils, with a higher ratio $(>1.0)$ typical of fertile soil, but serpentine soil has a low calcium-magnesium ratio. Its other characteristics are levels of nitrogen, potassium, and phosphorus far below what is needed for crop plants, and the presence of heavy metals chromium, nickel, and cobalt. This elemental combination - along with other factors such as low molybdenum, low clay content, poor water retention, and a lack of biota produces a soil restrictive to many plant species, but favorable to certain 
endemics (Kruckeberg, 1984; Carter, 2002). The result is referred to as the "serpentine effect" or "serpentine syndrome." This is borne out in the fact that the serpentine-composed ridge of RCNR has much different flora than the nearby morros of San Luis Obispo, Cerro San Luis and Bishop's Peak, which are composed of igneous dacite rock (Carter, 2002).

Carter's (2002) biological study of Reservoir Canyon revealed numerous, rare serpentine endemics, including the endangered Chorro Creek bog thistle (Cirsium fontinale var. obispoense). Other rare species include the San Luis and club-haired Mariposa lilies (Calochortus obispoensis and Calochortus clavatus), Brewer's spineflower (Chorizanthe breweri), San Luis Obispo Dudley (Dudleya abramsii ssp. murina), small leafed lomatium (Lomatium parvifolium), and alkali groundsel (Senecio aphanactis). The presence of rare plants in RCNR is both a justification for the existence of the natural reserve itself and for the conservation plan to prescribe continual biological monitoring of the property.

\section{Wildfire Protection}

Wildfire protection is a key concern of the RCNR Conservation Plan, given the area's fire history and continuing vulnerability, as well as the wildland-urban interface on the Bowden Ranch side of the property. The last major fire in the canyon itself was the Las Pilitas fire in July of 1985 , which burned a total of 75,000 acres in San Luis Obispo County. More recent major wildfires in the County include the Highway 41 (1994) and Highway 58 (1996) fires; the first of 
which nearly reached the City of San Luis Obispo. The grassland and scrub areas in Bowden Ranch have a relatively lower hazard due to the lower fuel load (relative to a forest) and the fact that they are on a steep slope. Fire usually burns uphill due to typical airflow patterns uphill and convected heat rising along the slope, creating a draft that increases fire spread (British Columbia Wildfire Management Branch, 2011).

Of greatest concern are the eucalyptus groves at the westernmost edge of Bowden Ranch. While eucalyptus's oily leaves are obviously flammable, they are moderately-to-highly resistant to fire when green or juvenile. So it is the annually shed bark and the dry, dead leaf litter and duff that represents the greatest hazard (NPS, 2006). Compounding the threat is the fast-growing nature of eucalyptus, which produces an annual fuel load of 30.84 tons per acre, according to the National Parks Service (2006), which is nearly three times as much as native coast live oak (a species also present in RCNR). Agee et al. (1973) recommend a "continuing short-rotation fuel reduction program." As long as the trees on City property are desired for shade and aesthetic reasons, regular clearing of duff and litter, and removal of lower tree limbs, represent the most practical choice for fuel management in RCNR, since controlled burning is not feasible in close proximity to residences. 


\section{Trail Management}

\section{Erosion}

Trail maintenance is important for both the visitor experience and the mitigation of erosion damage. Dorwart, Moore, and Leung (2009) note that "if a trail is badly eroded or widened, then the hiker's experience might not be as satisfactory because people prefer that trails be compatible with the natural surroundings." However, they also point out that if beautiful views or waterways are along the trail, environmental disturbances might not be as noticeable, because they "may make visitors less perceptive of impacts or the presence of others on the trail, or if they do perceive these elements the effect on their overall experience may be reduced as a result." These points seem to confirm what may be intuitively surmised, that a trail is a means to an end, and the aesthetic, physical qualities of the trail itself are less important than the aesthetics of the surrounding environment. From that standpoint, RCNR's trail network should be maintained for continued functionality - safely conveying visitors to the numerous scenic vistas - but not necessarily for the beauty of the trail itself.

Trail erosion due to user impact is an issue at RCNR. To monitor such impacts, Marion, Leung, and Nepal (2006) offer two categories of methods: sampling- and census-based approaches. Sampling approaches employ either (1) systematic point sampling, which conducts tread assessments over a fixed interval along the trail, or (2) stratified point sampling, which varies sampling intervals according to such factors (strata) as vegetation type or level of use. 
Census-based approaches utilize (1) sectional evaluations, where trails are divided and assessed by section, or (2) continuous assessments that record all occurrences a pre-defined impact. Where time and funds are available, censusbased approaches would probably benefit RCNR more due to their comprehensiveness. However, sampling methods might still suffice, particularly if combined with a census-style approach. For example, systematic point sampling within pre-defined trail sections would yield a sampled sectional evaluation. Another low-cost monitoring solution is to develop a condition-class system for assessing impacts. Rather than using quantitative measurements for any of the sampling or census methods described above, monitoring programs can employ a set of qualitative descriptions to be used in rating trail conditions as lightly, moderately, highly, or severely damaged. Subjectivity in applying the condition-classes is the disadvantage of this system, but that should be weighed against the time saved from not having to take detailed quantitative measurements, and from the simplicity of presenting findings (Marion, Leung, and Nepal, 2006). Further, to reduce subjectivity and inconsistency, the City could develop guidance documentation that provides definitions and several clear examples of each condition-class. The condition-classes could also be scaled to fit the context of the trails and trail damage observed in the City's open spaces, rather than some general definition of trail conditions. 


\section{New Trails}

One of the considerations of the RCNR Conservation Plan is completing a loop trail so that visitors could reach the parking lot from the ridge top by hiking down through the north side of the property. An informal path already exists down the ridge in this area. Part of the vegetation was removed as part of PG\&E's easement access to maintain their electrical towers. However, users have followed the clear-cut path for a quicker, albeit much steeper, way down the mountain. The combination of PG\&E and visitor usage has led to erosion on the slope.

The literature discusses several trail characteristics that can be managed to minimize erosion. The management practices are applicable to both maintaining existing trails and constructing new ones. Olive and Marion (2009) suggest employing shallower trail grades (steep = worse), creating outlsoping treads (trail paths lower on the outside or downhill side of the trail than it is on the inside or bankside), and building in grade reversals (short dips in the trail followed by slight, gradual rises). These are echoed in the U.S. Forest Service's Trail Construction and Maintenance Notebook (Hesselbarth, Vachowski, and Davies, 2007), which prescribes placing grade reversals every 20 to 50 feet and outsloping the tread by at least five percent. Taking advantage of natural dips for grade reversals helps ease this process, and at their inception trails should ideally be routed to do so. 
Trails routed across slopes, rather than directly down slopes, have significantly less soil loss because the terrain on one side of the trail is always lower, which allows better drainage through outsloping (Olive and Marion, 2009). While alignment with slopes may be easier and less costly to create initially, and in fact may have been formed informally by users, side-hill trails are "inherently more sustainable" because they suffer less erosion damage over time (Olive and Marion, 2009). The overall intended effect of this and the other methods described is to move water off the side of the trail in sheets to avoid erosive drainage down the trail itself. However, a secondary benefit is to enhance user enjoyment of the trail in creating an up-and-down motion (Hesselbarth, Vachowski, and Davies, 2007).

The implication for Reservoir Canyon's proposed loop trail is simply that if a trail is constructed, it should adhere to the side of the hill rather than the slope. Therefore, the existing informal trail should be restored to habitat conditions and become off limits to visitors and PG\&E alike. But the new trail should also pass by the tower maintenance areas, allowing continued access for PG\&E. 


\section{References}

Agee, J. K., Wakimoto, R. H., Darley, E. F., \& Biswell, H. H. (1973, September). Eucalyptus Fuel Dynamics and Fire Hazard in the Oakland Hills. California Agriculture, 13-15.

British Columbia Wildfire Management Branch. (2011). Fire Behaviour. Retrieved May 18, 2012, from http://bcwildfire.ca/FightingWildfire/behaviour.htm

Carter, B. E. (2002). Vegetative Survey of the Old Hasting's Property, San Luis Obispo County, CA and Serpentine Literature Review. California Polytechnic State University, San Luis Obispo.

City of San Luis Obispo. (n.d.). Reservoir Canyon trail guide. Retrieved from http://www.slocity.org/naturalresources/images/trail\%20guide_reservoir.pd f

City of San Luis Obispo. (2011b). Reservoir Canyon. Retrieved from http://www.slocity.org/parksandrecreation/reservoir_canyon.asp

City of San Luis Obispo. (2011a). Bowden Ranch. Retrieved from http://www.slocity.org/parksandrecreation/bowden_ranch.asp

City of San Luis Obispo. (2002). Conservation Guidelines for Open Space Lands of the City of San Luis Obispo. Retrieved from http://www.slocity.org/naturalresources/download/SLO_opnspcWEB.pdf

City of San Luis Obispo. (2006). The general plan, chapter 6: conservation and open space. Retrieved from http://www.slocity.org/communitydevelopment/download/unifiedgeneralpla n/Chapter6-COSE.pdf

Cole, D., \& Yung, L. (2010a). Park and wilderness stewardship: the dillemma of management intervention. Beyond naturalness: rethinking park and wilderness stewardship in an era of rapid change (pp. 1-11). Island Press.

Cole, D., \& Yung, L. (Eds.). (2010b). Beyond naturalness: rethinking park and wilderness stewardship in an era of rapid change. Washington DC: Island Press.

De Rome, D. (1997). Poly Land Revisited: A Field Guide. California Polytechnic State University, San Luis Obispo. Retrieved from http://polyland.calpoly.edu/overview/Archives/derome/index.html 
Dorwart, C. E., Moore, R. L., \& Leung, Y.-F. (2009). Visitors' Perceptions of a Trail Environment and Effects on Experiences: A Model for Nature-Based Recreation Experiences. Leisure Sciences, 32(1), 33-54. doi:10.1080/01490400903430863

Groves, C. (2003). Drafting a Conservation Blueprint: A Practitioner's Guide to Planning for Biodiversity. Washington: Island Press.

Hesselbarth, W., Vachowski, B., \& Davies. (2007). Trail Construction and Maintenance Notebook ( No. 0723-2806-MTDC). U.S. Forest Service; U.S. Department of Transportation - Federal Highway Administration. Retrieved from http://www.fs.fed.us/t-d/pubs/htmlpubs/htm07232806/index.htm

Holling, C. S. (2009). The resilience of terrestrial ecosystems. Foundations of ecological resilience (pp. 67-118). Washington DC: Island Press.

Kruckeberg, A. R. (1984). California Serpentines: Flora, Vegetation, Geology, Soils, and Management Problems. Berkeley: University of California Press.

Leopold, A. (1987). A Sand County Almanac, and Sketches Here and There: With Other Essays on Conservation from Round River. New York: Oxford University Press.

Marion, J. L., Leung, Y. F., \& Nepal, S. K. (2006). Monitoring trail conditions: New methodological considerations. George Wright Forum (Vol. 23, pp. 3649).

Maser, C. (1999). Ecological diversity in sustainable development: the vital and forgotten dimension. Boca Raton Fla.: Lewis Publishers.

National Park Service. (2006). Eucalyptus: A Transcontinental Legacy, Fire Management, Resource Protection, and the Challenges of the Tasmanian Blue Gum. Retrieved from http://biomass.forestguild.org/casestudies/1001/Eucalyptus.pdf

Olive, N. D., \& Marion, J. L. (2009). The influence of use-related, environmental, and managerial factors on soil loss from recreational trails. Journal of Environmental Management, 90(3), 1483-1493. doi:10.1016/j.jenvman.2008.10.004

Ryan, J. (1992). Life support: conserving biological diversity. Washington D.C.: Worldwatch Institute. 
Siikamaki, J., \& Chow, J. (2008). Biodiversity in the United States. Perspectives on sustainable resources in America. Washington DC: Resources for the Future.

Sutherland, W. (2000). The conservation handbook: research, management, and policy. Malden MA: Blackwell Science.

Underwood, J. G. (2011). Combining Landscape-Level Conservation Planning and Biodiversity Offset Programs: A Case Study. Environmental Management, 47, 121-129. doi:10.1007/s00267-010-9589-9 


\section{APPENDIX: Reservoir Canyon Natural Reserve Conservation Plan (Project Draft)}

The attached document is the draft Conservation Plan submitted to the City's Natural Resources Program in fulfillment of my project obligations there, and has separate page numbering. A subsequent draft, or the final document, may be obtained by contacting the City. 
RESERVOIR CANYON NATURAL RESERVE Draft Conservation Plan
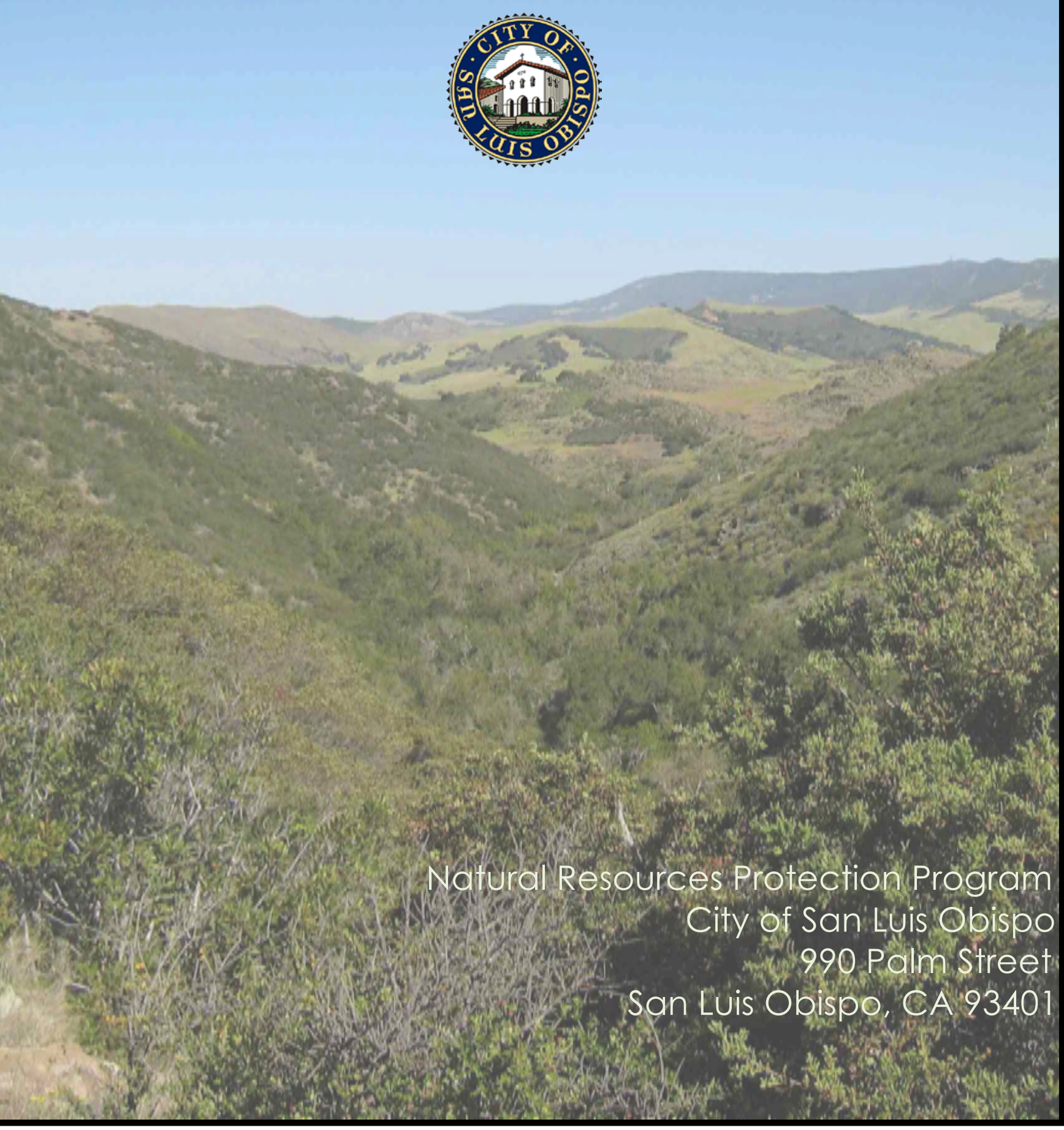


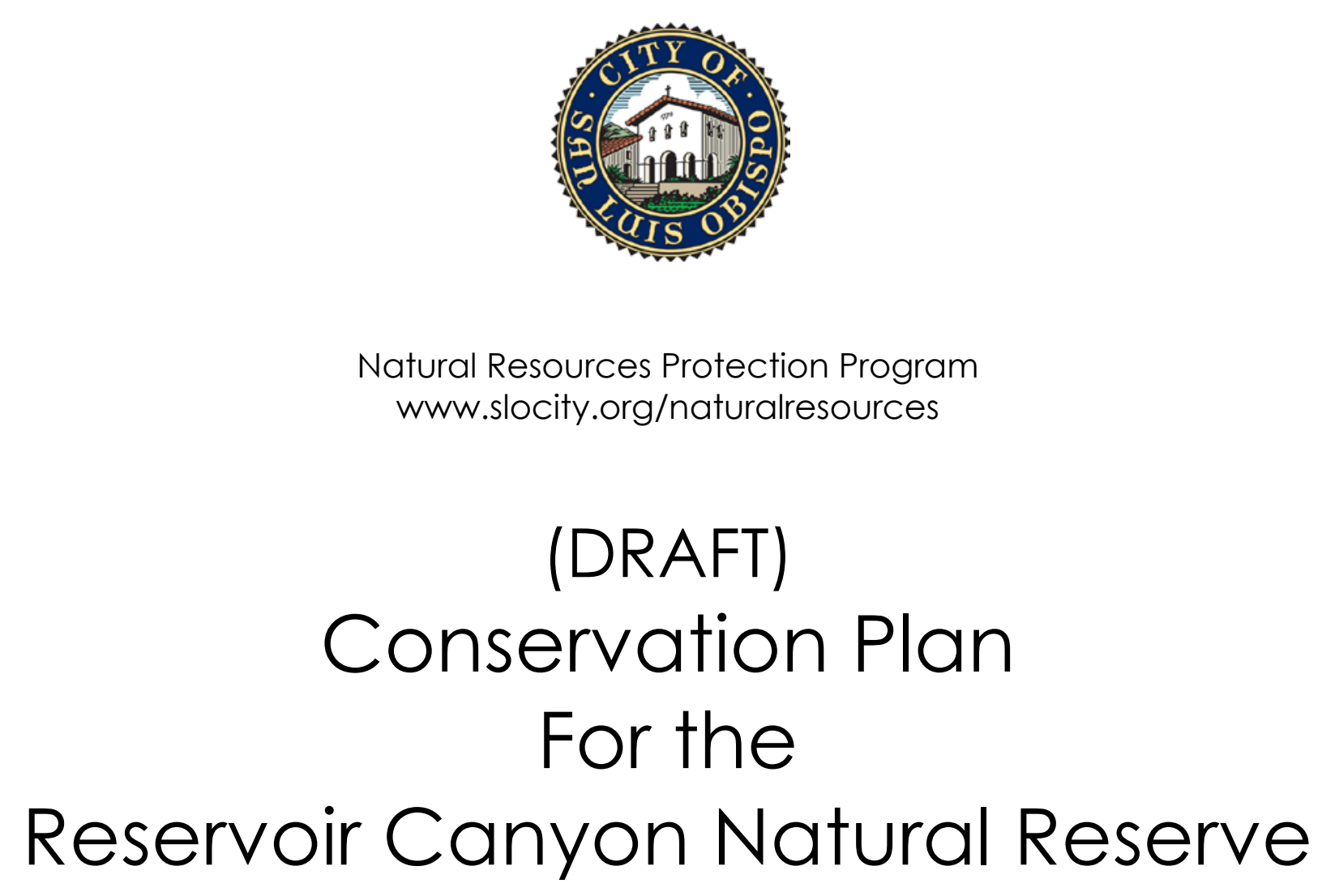

Neil Havlik, Ph.D.

Natural Resources Manager

805.781 .7211

Freddy Otte

City Biologist

805.781 .7511

\section{Brian Provenzale}

Natural Resources intern

Masters Candidate, City and Regional Planning

California Polytechnic State University, San Luis Obispo 


\section{Table of Contents}

PAGE

List of Figures \& Tables

Executive Summary

3

1. Introduction

4

1.1 History

1.2 Natural Features

6

1.3 Access

7

7

2. Inventory

2.1 Physical Inventory

2.2 Cultural and Historic Features

2.3 Legal Agreements

2.4 Soils

2.5 Water Resources

7

2.6 Habitat Types (with Associated Plants \& Wildlife)

7

7

9

10

10

3. Goals and Policies

4. Conservation Plan

4.1 Naming

4.2 Land Use Designations

15

4.3 Photo-Monitoring Points

4.4 Needs Analysis

5. Wildfire Preparedness Plan

6. Implementation

7. Fiscal Statement

8. Amendment

Appendices

A. Proposed Reservoir Canyon Master Plan 23

(1980's Cal Poly Student Project)

B. Hastings Trail Easement Deed and Transcript 24

C. Trutio Deed 26

D: Soils of Reservoir Canyon Natural Reserve 28

E: Plants 29

F: Notes From January 31, 2012 Initial Public Meeting 33

G: Photo-Monitoring Points 36

$\mathrm{H}$ : Wildfire Jurisdictional Responsibility Areas in RCNR 46

I: An Archaeological Surface Survey for Existing Trails \& Proposed 47

Trail Extension at the Reservoir Canyon Area 


\section{List of Figures \& Tables}

PAGE

\section{FIGURES}

Figure 1: Reservoir Canyon Natural Reserve property map

Figure 2: City of San Luis Obispo Open Spaces with 5 RCNR plan area highlighted

Figure 3: Views of the filled-in reservoir in the canyon 6

Figure 4: Physical, cultural, and historical features of RCNR 8

Figure 5: Soil textures in RCNR 10

Figure 6: Habitat types in RCNR 11

Figure 7: RCNR land use designations 16

Figure 8: RCNR fire hazard classification 20

$\begin{array}{ll}\text { Figure 9: RCNR fire mitigation areas } & 21\end{array}$

Figure APP 1: Soil types in the Reservoir Canyon area 28

Figure APP 2: Wildfire Jurisdictional Responsibility Areas in RCNR 46

\section{TABLES}

Table 1: Notable Plant Species in RCNR $\quad 12$

Table 2: USGS Soil Survey - Reservoir Canyon Area $\quad 27$ 


\section{Executive Summary}

Reservoir Canyon Natural Reserve (RCNR) is located just northeast of the City of San Luis Obispo and is situated on nearly 700 acres of open space owned by the City. It contains the Reservoir Canyon and Bowden Ranch open spaces, with an expected addition of the Goldtree tract in 2012.

\section{Natural Features}

The canyon features a perennial creek fed by several streams, which contribute to a rich and diverse natural setting. Several habitat types comprise RCNR, including chaparral, serpentine coastal scrub, serpentine grassland, and riparian. Key plant species include mariposa lilies, owl's clover, Indian paintbrush, spineflowers, and the endangered Chorro Creek bog thistle.

\section{Management Issues}

The plan provides guidance and programs to address several management issues in RCNR:

- Conservation. The plan seeks to balance the needs of maintaining the natural ecosystem with public recreational and other uses.

- Legal agreements. These include a trail easement across private property, a PG\&E power line maintenance easement, and shared water rights with neighboring properties.

- Trail and slope erosion. Erosion is particularly noticeable near the creek crossings.

- Signage. The property has outdated and limited signage that inadequately educates public users about off-trail hiking and the natural and cultural history of the property.

\section{Goals \& Policies}

The RCNR Conservation Plan has as its overarching goal to balance conservation of sensitive habitats with public and utility company use of the open space. The plan will accomplish this goal, and address the management issues described above, through the following policies:

- Conserve, enhance, and restore natural plant and wildlife communities; protect sensitive endangered plant and wildlife species and their habitats; and maintain biodiversity of native plants and animals by protecting their habitats in order to maintain viable wildlife populations within balanced ecosystems.

- Provide the public with a safe and pleasing natural environment in which to pursue passive recreational activities, while maintaining the integrity of the resources and minimizing the impacts on the wildlife and habitats present in the Reserve.

- Preserve and restore creeks, wetlands, and ephemeral seeps or springs to a natural state, and provide suitable habitat for all native aquatic and riparian species.

- Minimize the impacts of harmful activities, such as off-trail hiking and utility access, while maintaining natural drainage systems as a means of conveying storm water into and within urban areas.

- Provide signage and interpretive features to prevent unauthorized entrance at neighboring private property, and for educational purposes.

- Maintain, protect, and improve aesthetic views as seen from the City of San Luis Obispo. 


\section{Introduction}

Reservoir Canyon Natural Reserve (RCNR) is a place of exceptional beauty, blending a rich ecosystem with spectacular views from the ridge overlooking the City of San Luis Obispo and its surroundings. It offers a unique opportunity for passive recreation within an environment full of native and rare plants. Once known as Fillmore Canyon, the area took its name from a publicly owned reservoir the operated in the first half of the twentieth century. A 1985 fire destroyed much of the vegetation in the canyon, filling in the then-abandoned reservoir in the process. Since that time, the ecosystem has made a remarkable comeback with very little human assistance. It is therefore the primary goal of this plan to preserve and protect the natural habitats comprising RCNR, mindful of the fact that the ecosystem is intact and resilient.

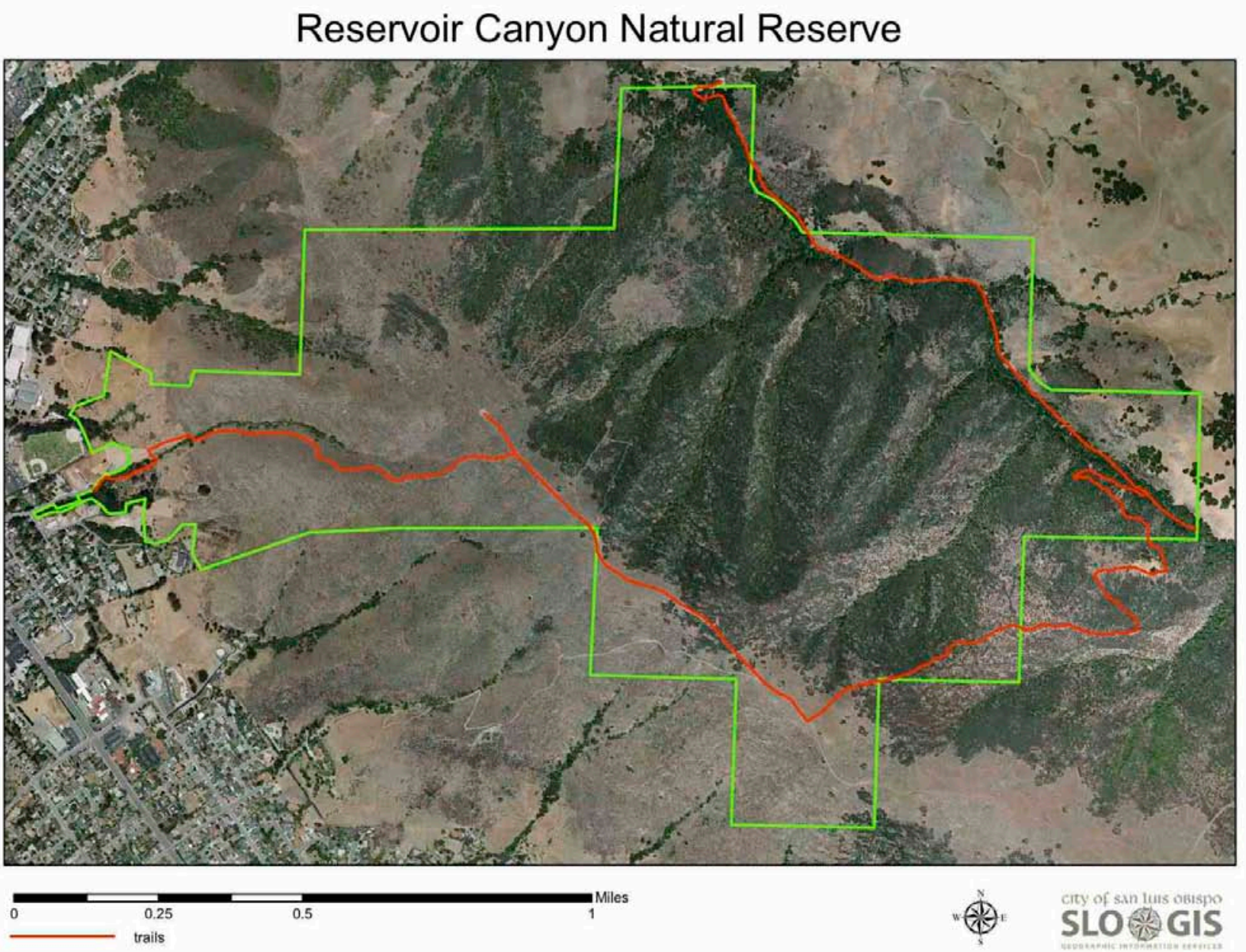

Figure 1: Reservoir Canyon Natural Reserve property map.

RCNR is located just northeast of the City of San Luis Obispo. It is situated on nearly 700 acres of open space owned by the City and features a perennial stream and a variety of natural habitats. It contains the Reservoir Canyon and Bowden Ranch open spaces and is expected to include the adjacent Goldtree tract in 2012, pending the City's acquisition of that property.

The creation of a conservation plan for RCNR is motivated by the City's General Plan Conservation and Open Space Element policy, which states: "The City will adopt conservation plans (or master plans with conservation components) for large parcels, and for small parcels where conservation challenges and solutions need to be clarified" (from Appendix C of the Conservation and Open Space Element, p.77). 
In addition to satisfying the above policy, and in adherence to the City's Conservation Guidelines for Open Spaces, this plan has a threefold purpose: to provide an account of the prevailing condition of the Reservoir Canyon Natural Reserve; to set out future conservation and management goals for the property; and to prescribe a means of achieving those goals.

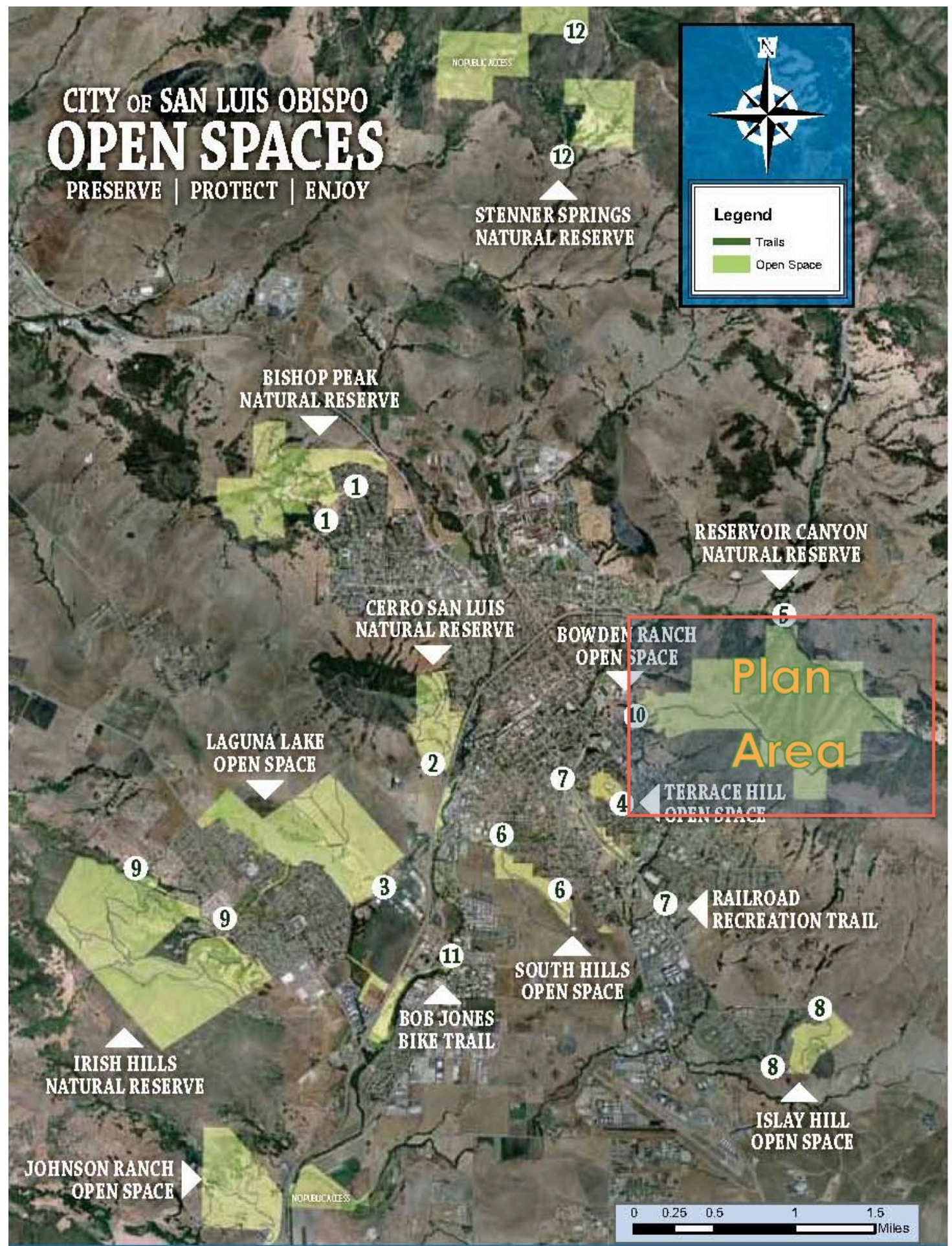

Figure 2: City of San Luis Obispo Open Spaces with RCNR plan area highlighted. Numbers indicate trail entrances for each open space property. 


\subsection{History}

Reservoir Canyon was identified very early in the history of the City of San Luis Obispo as a source of reliable water of good quality. In the late 1800's the private San Luis Obispo Water Company purchased about 200 acres of land in the canyon and constructed several small diversion dams to divert water out of the creek and a series of pipelines to carry the water to a distribution reservoir just below the canyon. The company also constructed an earthen dam at the mouth of the canyon to also capture water for distribution into the City's water supply. It was this structure that gave the name Reservoir Canyon to the area; prior to that time it had been known as Fillmore Canyon.

In 1900 the City of San Luis Obispo purchased the water company in its entirety and became the water purveyor for the community. At that time the water collection system consisted of several diversion structures on San Luis Obispo Creek and several of its tributaries, including Reservoir Canyon Creek, Hansen Creek, and Gularte Creek, as well as the dam on Reservoir Canyon Creek. The purchase of the water company also included property for a potential dam site on Stenner Creek; however, this dam was never built.
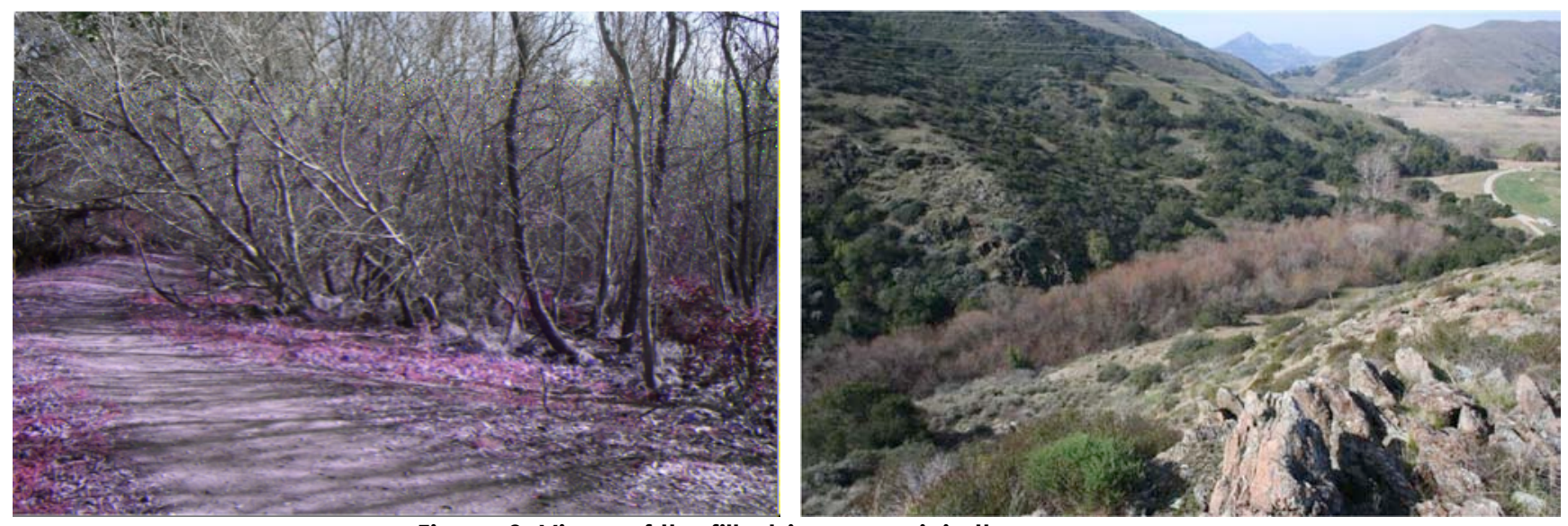

Figure 3: Views of the filled-in reservoir in the canyon

These facilities continued to operate into the 1950's. By this time the City had secured rights to water from the Salinas Reservoir, constructed in 1942 by the U.S. Army Corps of Engineers as part of the war effort to supply water to Camp San Luis Obispo, which was a major training facility during the war. With such a large water supply available, the smaller local supplies became uneconomical to continue to operate and were eventually abandoned as part of the City's water supply. However, among the agreements with landowners along the route of the pipeline from upper San Luis Obispo Creek was a provision that the City would continue to supply those landowners from the pipeline. Thus the City was required to maintain the pipeline system for many years until finally being released from that requirement by negotiation in the 1990's.

Today all that remains of the local water supply system are remnants of a diversion dam on San Luis Obispo Creek (partially demolished to improve fish passage), a few sections of pipeline, some remains of small concrete diversion dams in the tributary creeks, including Reservoir Canyon Creek, and the dam face at the mouth of Reservoir Canyon. The reservoir itself has fully silted in and only holds a small volume of open water; it is instead a willow swamp. Water still flows over the reservoir's outlet in a 15foot waterfall, which is a popular walking destination for visitors.

In the 1980's landscape architecture students at Cal Poly San Luis Obispo created a master plan for Reservoir Canyon. The plan is notable for the fact that it focuses on the use of Reservoir Canyon as park and picnic grounds, which conflicts with the City's current policies and values to protect and preserve the natural qualities of City open space areas. Appendix A has a few selected concept diagrams from that proposed master plan. 
As part of the 1994 General Plan update, the City Council formally declared that the Reservoir Canyon property would be kept as a portion of an open space system envisioned for the community. Since that time the 284-acre Hastings property and 207-acre Bowden Ranch property have been added to Reservoir Canyon, bringing it up to its current total area of 694 acres. Currently the City is negotiating with another party to add 89 acres to Reservoir Canyon, which would bring the total to 783 acres.

The Reservoir Canyon area has some history of mineral exploration. At least four small prospects exist on the hillside on both side of the ridgeline west of Reservoir Canyon. The age, extent, and details of these explorations are unknown. It is believed that prospecting was for chromite, which is the main mineral of economic value in the serpentine hills around San Luis Obispo. Evidently, chromite was never found in economically viable quantities and the prospects were abandoned.

\subsection{Natural Features}

Rich plant and wildlife habitats compose Reservoir Canyon. The area consists of mostly steep terrain ranging from 400 feet to 1,715 feet in elevation and is the southern boundary for a large mammal migratory corridor. Chaparral covers the north ridge, with perennial grassland on the south ridge. Serpentine outcroppings provide another habitat for rare plant species adapted to the unusual soil conditions. Two perennial creeks fed by numerous springs and seeps along the ridge flow through the property, forming riparian habitats at the bottom of the canyon, and are home to steelhead trout descendents. The creeks are also responsible for erosion in small areas of the property, particularly along the trail near both the Reservoir Canyon and Bowden Ranch entrances.

\subsection{Access}

Two trailheads provide access to RCNR: The first is the north entrance from Reservoir Canyon Road, which is one mile north of San Luis Obispo, east off of Highway 101. The road is unpaved near the RCNR entrance, and parking is available at the side of the road. The second access point is at the Bowden Ranch trailhead, on the east end of Lizzie Street in San Luis Obispo itself. This location offers on-street parking and a bicycle rack.

\section{Inventory}

\subsection{Physical Inventory}

The Reservoir Canyon trail spans over 2.5 miles from the trailhead at Reservoir Canyon Road to the top of the ridge. From the ridge, the trail connects to the Bowden Ranch trail, which runs 0.9 miles down a steep hillside to the property's other trailhead at the east end of Lizzie Street in San Luis Obispo. Currently, there is no loop system for the trails. Other features include a pair of stone benches on the ridge top and rock piles left by visitors at a few points along the ridge and trail.

\subsection{Cultural and Historic Features}

In addition to the natural and physical features, RCNR is notable for its cultural features. Most remarkable are the views of the City of San Luis Obispo from the top of the ridge and the line of morros. Similarly, the view of the property and ridge from within the City make up part of the part of the City's geographic identity. An old air traffic beacon still stands at the northernmost point of the trail on the ridge. According to an archaeological consultant's May 2012 report (attached as Appendix I), no further archaeological studies should be necessary for the proposed policies and programs of this plan due to the lack of significant findings in the area. 
Figure 4: Physical, cultural, and historical features of RCNR

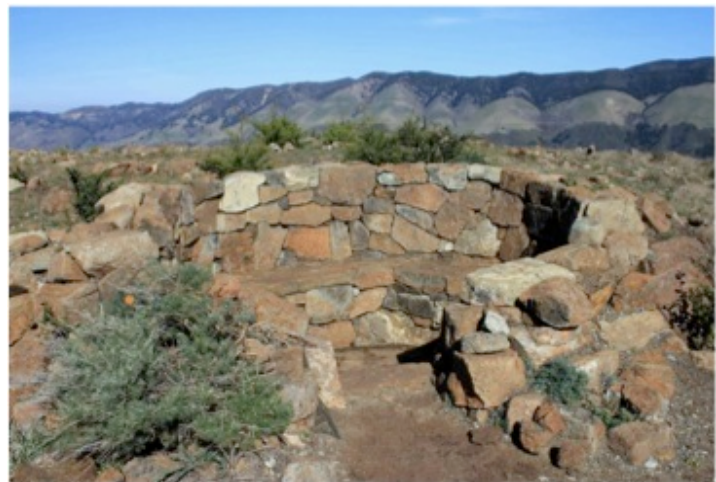

4a. Finished stone bench on the ridge

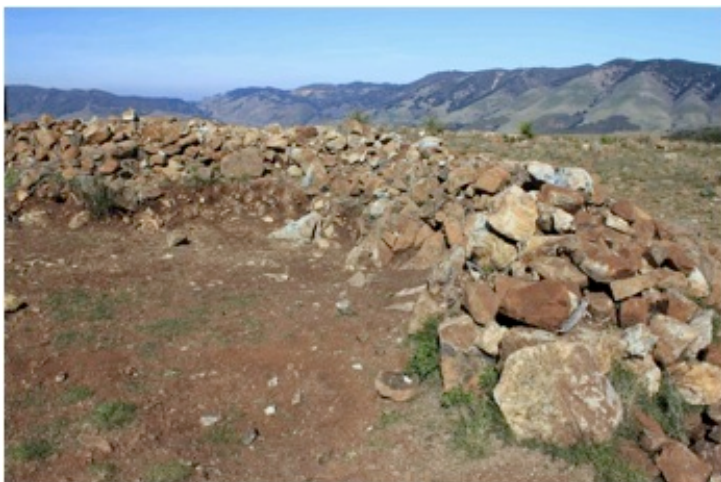

4b. Larger, unfinished stone bench on the ridge

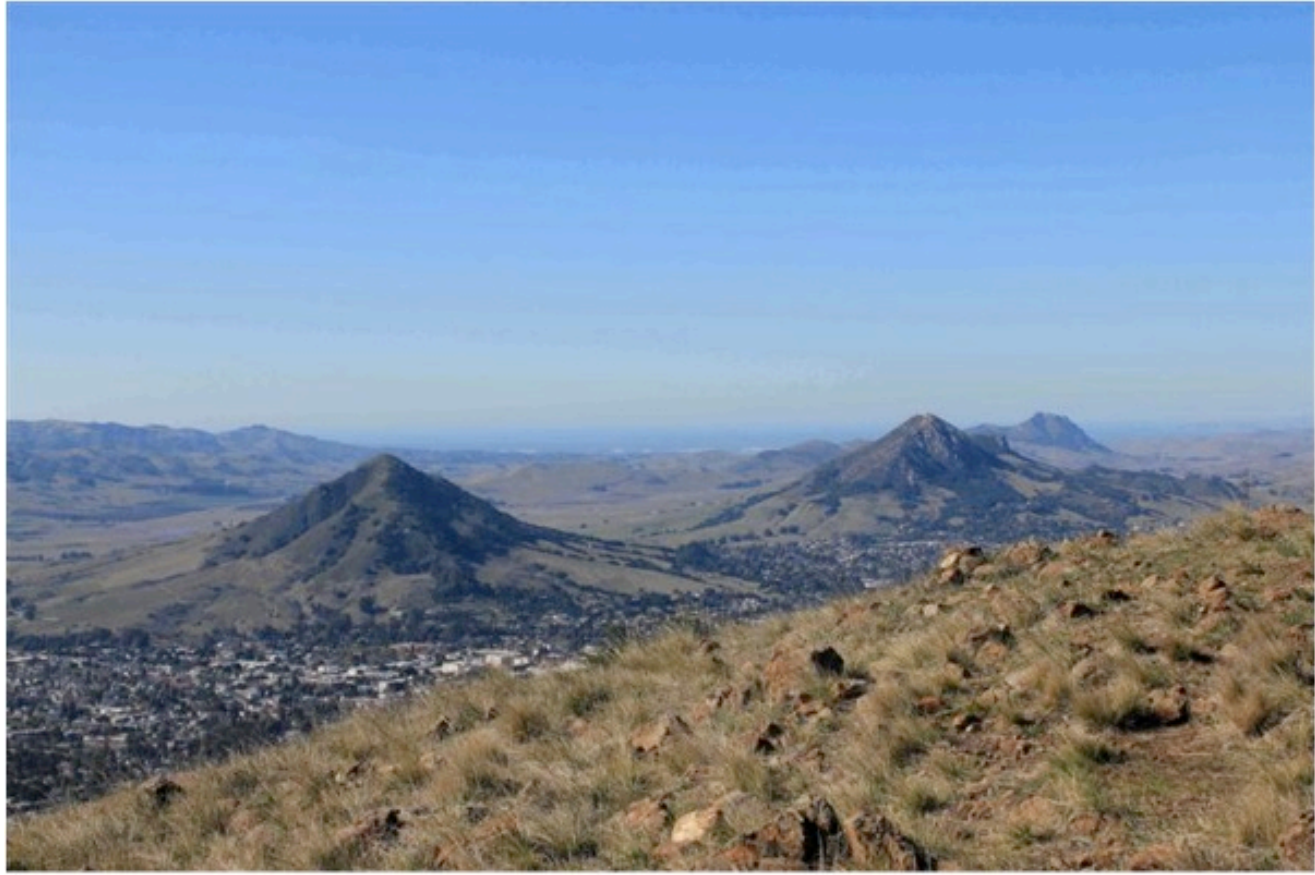

4c. A view from the ridge, facing northwest.

Cerro San Luis and Bishop's Peak are in the background.

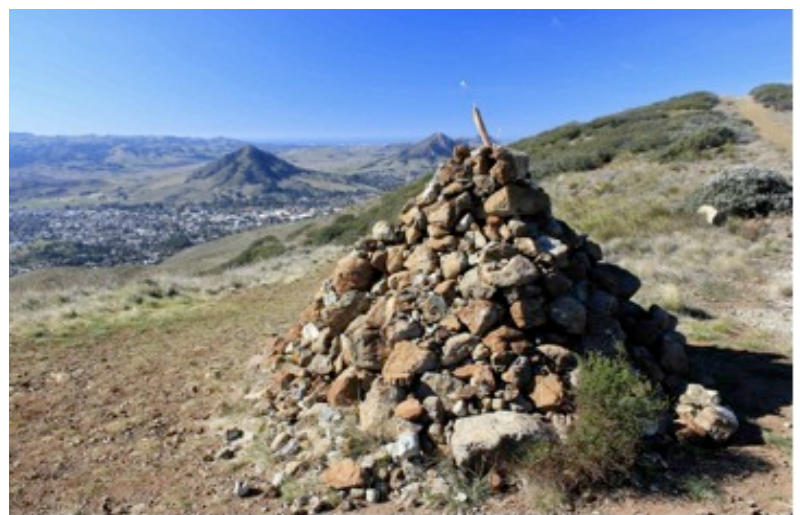

$4 d$. Rock pile along the ridge trail

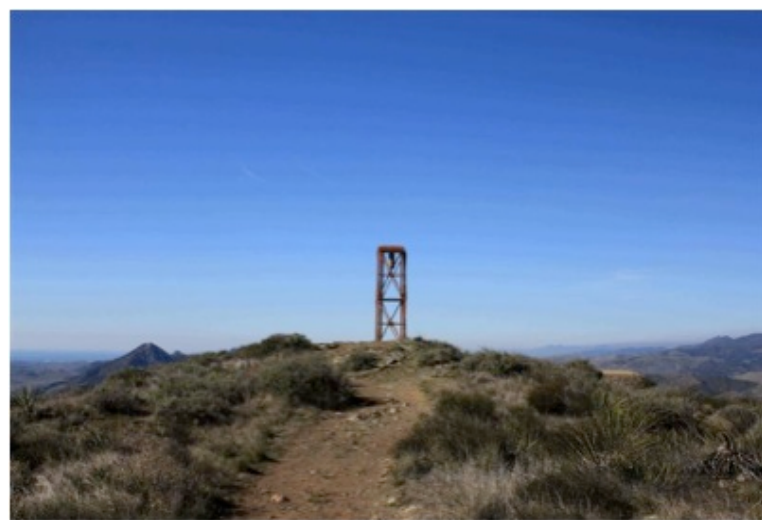

4e. Old air traffic beacon on the ridge top 
DRAFT Reservoir Canyon Conservation Plan

\subsection{Legal Agreements}

There are four legal agreements with important bearing on the use and functioning of Reservoir Canyon Natural Reserve.

By far the most important of these is the easement held by Pacific Gas and Electric Company (PG\&E) for their transmission line, which crosses RCNR from southwest to northeast. This line was originally constructed in the early 1900's. Today it is known as the Atascadero-Sam Luis Obispo 70kV line. It consists of a single line of towers carry 70 kilovolts $(\mathrm{kV})$ of electrical power. The towers consist of the so-called steel lattice type of construction, and are about 100 feet tall. PG\&E is in the process of replacing these towers for safety and supply reliability purposes. The easement grants PG\&E the right of reasonable access to the towers for maintenance and replacement purposes.

Another important legal agreement is the "floating" easement for road purposes across what is now known as the Michael Sheffer property. The Hastings family retained this easement when Edward J. Hastings sold a 40-acre portion of his property (specifically the northeast quarter or the northeast quarter of Section 31 in Township 30 South, Range 13 East, MDB\&M) to a son or other relative, Frank D. Hastings, in 1953. The grant deed memorializes the sale, including however the following exception:

"Also excepting and reserving unto the grantor herein an easement for road purposes over and across said land, at a site and location to be selected by or acceptable to the Grantor and his heirs and assigns and said easement to be of a width of not more than 50 feet. Said easement shall inure to the benefit of the heirs and assigns of the Grantor, and is intended to be used by and to benefit the owners of any of the lands and portions thereof retained by the Grantor so that the lands so retained or the portions of the lands can be held and enjoyed and the easement for road purposes be used and enjoyed without limit for any particular use by the Grantor and his heirs and assigns and the holders, owners and users of said easement."

The above language provides the legal right for the existing hiking trail crossing the Sheffer property, Mr. Sheffer being the successor in interest to Frank D. Hastings. See Appendix B for the complete agreement.

A third legal agreement permits watering of cattle in Reservoir Canyon Creek from the adjacent Trutio property. This agreement, which involved the purchase in 1911 of several small parcels of land by the City of San Luis Obispo from what was then called the Lowe property, allowed the City to fence off the creek from livestock, but if that were done the City would have to provide an alternative water source for livestock. Evidently this was never done, and the arrangement allowing livestock access to the creek has continued for more than 100 years, to the present day. Appendix $C$ has the complete text of this agreement.

A fourth legal agreement involves use of water from a spring on the Bowden Ranch portion of RCNR. This spring once provided water to the Bowden Adobe and the grounds surrounding it, but over the years the land was subdivided, the adobe fell into disuse, and the grounds were abandoned. In 2004, as part of the approval of a development agreement for the Bowden Ranch, approximately 207 acres of the 220-acre ranch was protected by dedication of fee title or easement interest to the City of San Luis Obispo. In 2008, full title to the Bowden Ranch property was obtained; however, as part of that transaction the seller retained the right to use of one-half of the natural flow of the spring. The practical effect of this retention is that the spring box, small storage tank along the Bowden Ranch Trail, and several water lines in the vicinity will remain functional for the foreseeable future. This does not appear to impair the use of the site by the City or by visitors.

It should be noted that at one time Reservoir Canyon Road extended at least one and a half miles farther up the canyon than it does today, but at some time (probably the late 1950's or early 1960's) the road was abandoned by the County of San Luis Obispo back to the point of its current terminus at the edge of RCNR. 


\subsection{Soils}

There are five major soil textures in RCNR, as depicted in Figure 5: clay; clay loam; loam; sandy; and unweathered bedrock, which is the dominant texture.

According to the US Geological Survey, there are 15 soil types in the greater Reservoir Canyon Area. Table 1 in Appendix D lists the types and their components. It accounts for the soil coverage type as a percentage of the overall acreage. The USGS data is also illustrated in a map in Appendix D. The dominant type is Obispo-rock outcrop or serpentine-derived soils, which, due to their inhospitableness for most species, often tend to favor native and rare California plant species. The next most common

\section{RCNR Soil Texture}

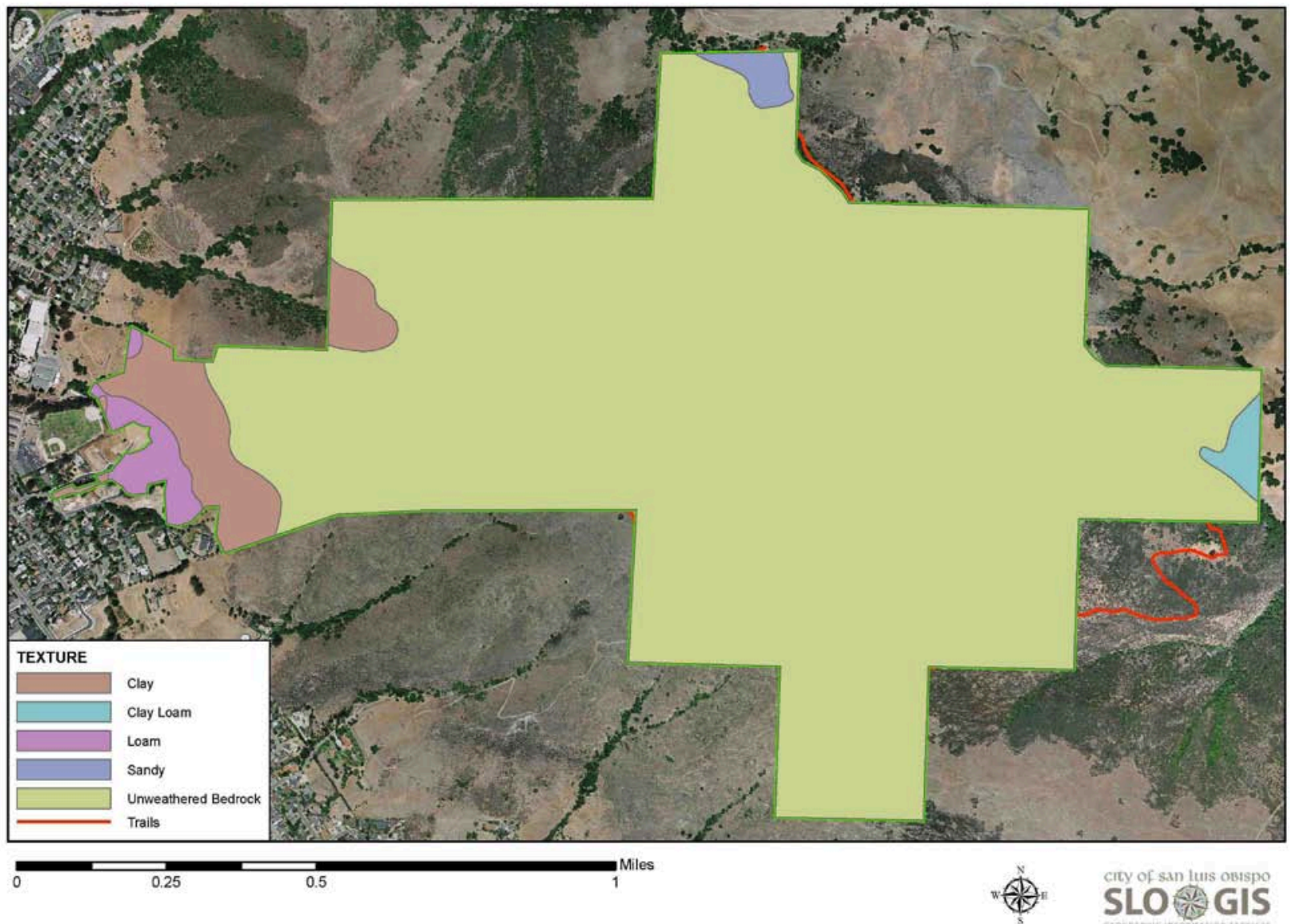

Figure 5: Soil textures in RCNR

type is the Los Osos-Diablo complex, occurring above shale bedrock. Usual vegetation in this soil type is mostly annual grasses and forbs with some perennial grasses, coastal sagebrush, and coast live oak. Gazos-Lodo clay loams comprise the third most common soil type in the RCNR area. This slightly acidic soil is commonly covered with vegetation consisting of annual grasses and forbs, with some brush and coastal live oak.

\subsection{Water Resources}

Water features include two perennial creeks - Reservoir Canyon Creek and West Corral de Piedra Creek - and the numerous springs and seeps that feed them. Along Reservoir Creek is the 15-foot waterfall at the site of the old reservoir's outlet. As stated in section 2.3, two legal agreements affect a 
portion of RCNR's water resources: A 1911 agreement permits watering of cattle in Reservoir Canyon Creek from the adjacent Trutio property. A second agreement, with the seller of the Bowden Ranch property, retains ownership of one half of the flow from one of the springs in the area.

\subsection{Habitat Types}

Reservoir Canyon Natural Reserve has four general habitat types: chaparral; coastal sage- and serpentine coastal sage scrub; serpentine grassland; and riparian. Figure 6 depicts these habitat types. Notable encountered plant species include Mariposa lilies (both the club haired and San Luis Obispo varieties), owl's clover/Indian paintbrush, spineflowers (both Brewer's and Palmer's varieties), star tulip, and Chorro Creek bog thistle, which are shown in Table 1. A full plant species list is available in Appendix E. Notable wildlife species encountered include mountain lion, skunk, deer (fawn), roadrunner, and white tailed kite. A full wildlife inventory will be completed at a later date and will be appended to this plan.

\section{RCNR Habitat Types}

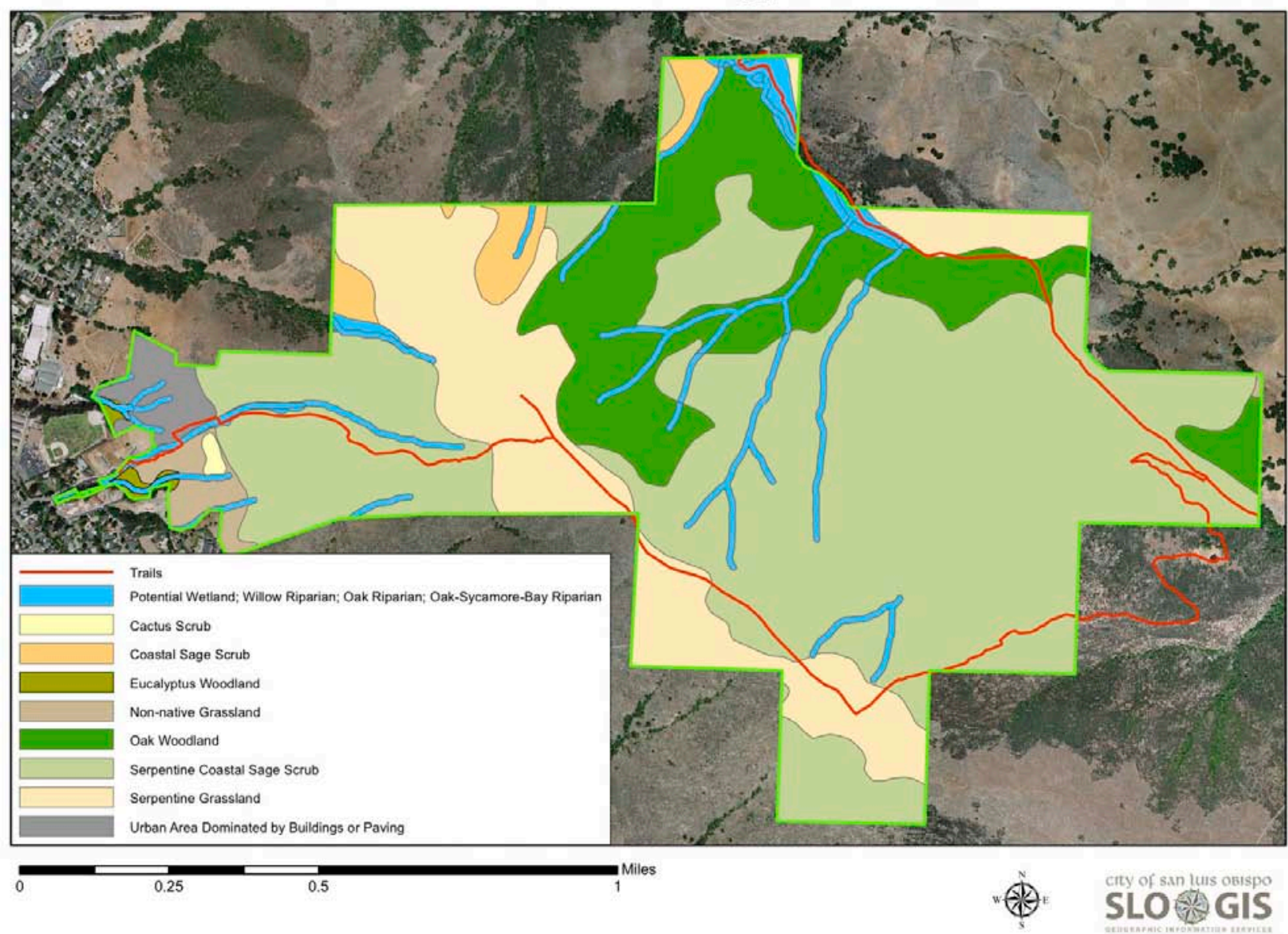

Figure 6: Habitat types in RCNR. 


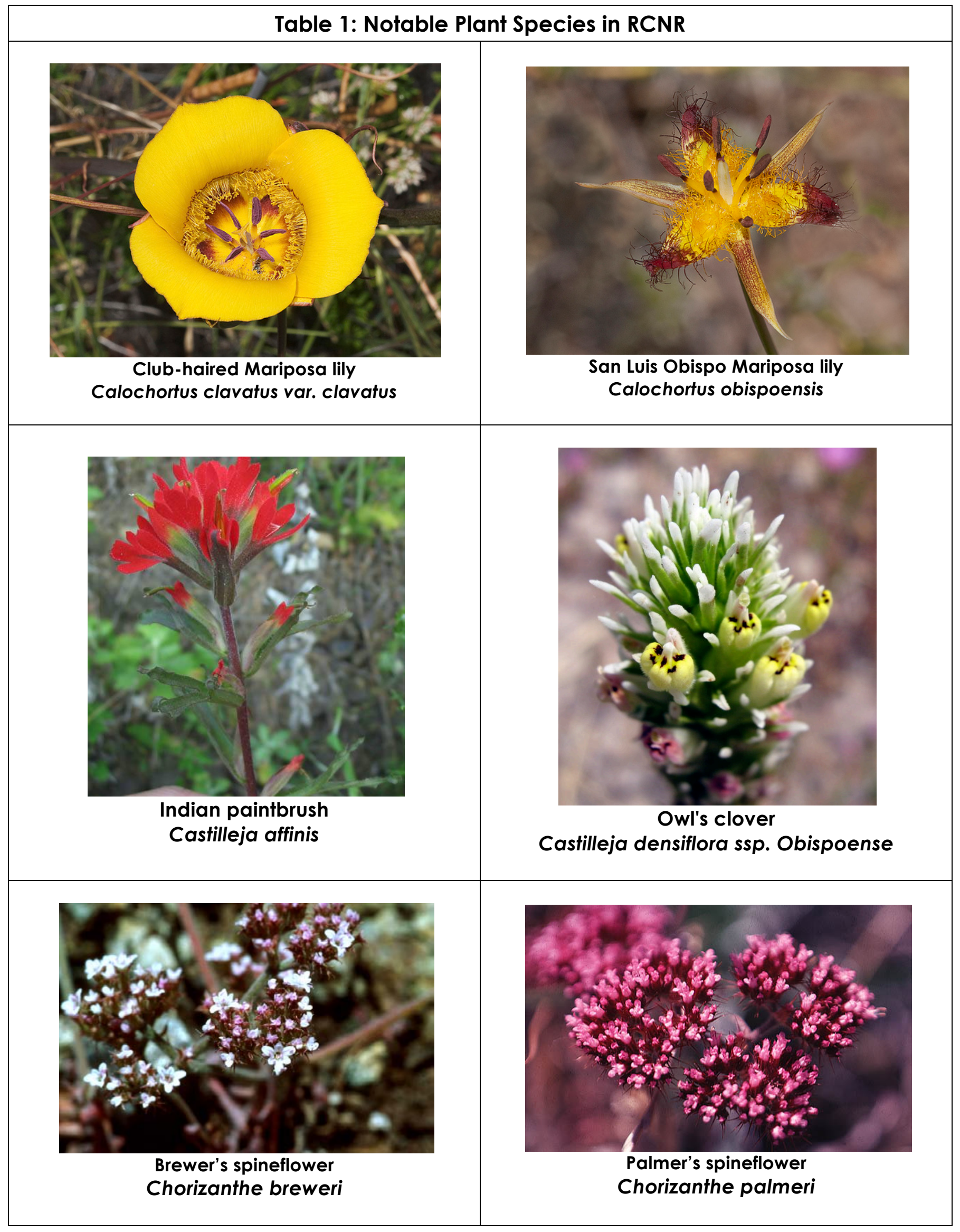



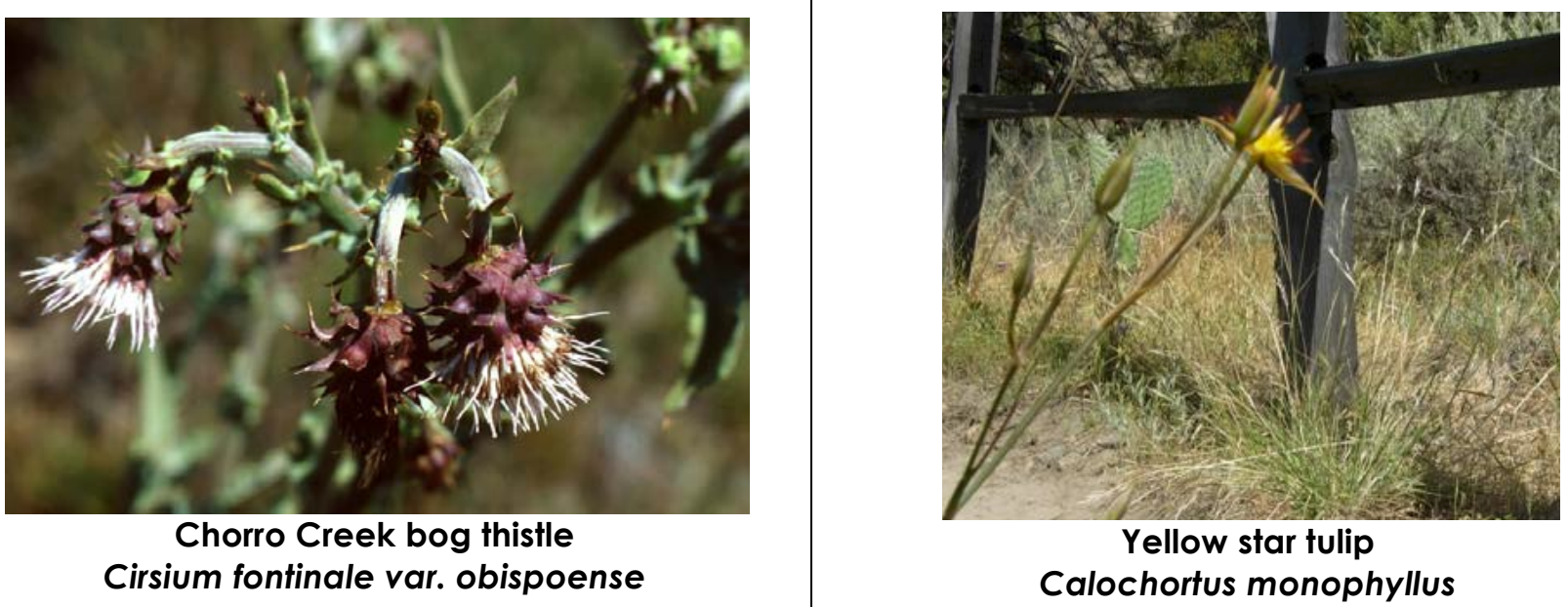

\subsubsection{Chaparral}

The north-facing slope of the Reservoir Canyon ridge has diverse vegetation due to relatively warm, moist conditions and protection from the wind. As is typical for chaparral habitats, the plants in this part of RCNR are full of woody, evergreen shrubs. The plants' dormant period coincides with dry, summer weather. Many plants in chaparral have reproductive cycles adapted to fires, with some requiring the heat of flames to germinate seeds. The currently thriving chaparral is likely a direct result of the Las Pilitas fire of 1985, which burnt much of Reservoir Canyon. Intervals for naturally occurring fires in chaparral are $30-40$ years on average, but can be as long as 100 years.

The chaparral habitat in RCNR includes the shrubs ceanothus (Ceanothus cuneatus), the rare San Luis Obispo spineflower and Brewer's spineflower (Chorizanthe breweri), and poison oak (Toxicodendron diversilobum). The main tree type is the California scrub oak (Quercus durata). Key grass, herb, and flower species include purple needlegrass (Nassella pulchra), giant wildrye (Leymus condensatus), Abrams' liveforever (Dudleya abramsii), and the California golden poppy (Eschscholzia californica).

\subsubsection{Coastal Sage Scrub and Serpentine Coastal Sage Scrub}

These habitats occupy the south-facing slope of RCNR, where the climate is windier and drier as compared to the north-facing slope. Plants typically have leaves that are softer and more aromatic than those in chaparral. Also unlike chaparral, sage scrub plants drop their leaves in summer. Serpentine outcroppings in RCNR's coastal sage scrub are extreme versions of the habitat due to the soil: only rare species can survive the inhospitable conditions. Fire intervals in typical scrub habitats often coincide with nearby chaparral. Plant species of note in the sage scrub habitats are various lilies (Calochortus) and the Indian paintbrush flower (Castilleja affinis).

\subsubsection{Serpentine Grassland}

The serpentine grassland, primarily on the ridge and the south-facing slope in RCNR, is a relatively pristine habitat in that it is dominated by native species. Within the last decade, the area was submitted by the City's Natural Resources Program to the state's Fire and Resource Assessment Program as a reference example of a natural grassland area. Due to the chemical composition and relative infertility of serpentine soil, a lower diversity of species is found. Yet, as a result, the soil also favors rare and native species. 
Grass species include several Bromus and most notably Avena barbata, however several native species including Melica species and Nassela species can be found in less hospitable areas of shallow, rocky soil. Notable wildflowers include coastal tidy tips (Layia platyglossa) and California golden poppies (Eschscholzia californica). Rare species include Mariposa lilies (both the San Luis Obispo and club haired varieties of Calochortus), most beautiful jewel flower (Streptanthus albidus subspecies peamoenus), brewer's spineflower (Chorizanthe breweri) and the succulent Abrams' liveforever (Dudleya abramsii).

\subsubsection{Riparian}

Riparian areas within City property on the north slope of the Reservoir Canyon ridge are fed by six drainages, which favors the species diversity in the canyon, including numerous species of shrubs, and a variety of trees, grasses, herbs, succulents, and most notably, ferns. The observed species of fern are: maidenhair (Adiantum jordanii), coffee (Pellaea andromedifolia), goldback (Pentagramma triangularis), and California polypody (Polypodium californicum). Tree species include California bay (Umbellularia californica), brewer's willow (Salix breweri), and coast live oak (Quercus agrifolia). Among the succulents, shrubs, and herbs are Abrams' and lanceleaf liveforevers (Dudleya abramsii and Dudleya lanceolata), poison oak (Toxicodendron diversilobum), and both the common seep and sticky monkey flower (Mimulus guttatus and Mimulus aurantiacus).

\section{Goals and Policies}

The document "Conservation Guidelines for Open Space Lands of the City of San Luis Obispo" describes management guidelines and policies designed to achieve the stated goals of the City's open space element (i.e. COSE 8.1-8.7).

\section{Goals}

The City will manage Reservoir Canyon Natural Reserve with the following goals:

3.1 To conserve, enhance, and restore natural plant and wildlife communities; to protect sensitive endangered plant and wildlife species and their habitats; and to maintain biodiversity of native plants and animals by protecting their habitats in order to maintain viable wildlife populations within balanced ecosystems.

3.2 To provide the public with a safe and pleasing natural environment in which to pursue passive recreational activities, while maintaining the integrity of the resources and minimizing the impacts on the wildlife and habitats present in the Reserve.

3.3 To preserve and restore creeks, wetlands, and ephemeral seeps or springs to a natural state, and provide suitable habitat for all native aquatic and riparian species.

3.4 To minimize the impacts of harmful activities, such as off-trail hiking and utility access, while maintaining natural drainage systems as a means of conveying storm water into and within urban areas.

3.5 To provide signage and interpretive features to prevent unauthorized entrance at neighboring private property, and for educational purposes.

3.6 To maintain, protect, and improve aesthetic views as seen from the City of San Luis Obispo. 


\section{Policies}

\subsection{Public Comment and Input}

This conservation plan seeks to accommodate the wishes and desires of the general public while addressing the City's goals in the Open Space Element. A public meeting was held in January 2012 as well as meetings with other groups for input on the conservation plan, and comments received during the review/approval process. (Notes and comments from the meeting are included in Appendix F.)

\subsection{Vegetation Management}

3.8.1 The City will monitor and manage vegetation to meet prescribed goals for the land. Management strategies such as the following will be implemented where necessary: physical pruning/removal of unwanted or problematic vegetation - especially non-native species; erosion and sediment control; and application of Integrated Pest Management practices.

3.8.2 Restoration and/or re-vegetation techniques will be utilized when necessary to restore a degraded vegetative community to a fully functioning ecosystem. All restoration activities will utilize site or regionspecific native grasses, herbs, shrubs, and trees. Planting of invasive, non-native species will be prohibited. Adjacent landowners will be encouraged to undertake efforts to control target non-native vegetation on their land.

3.8.3 All existing native trees will be preserved wherever possible, and new native trees planted to enhance wildlife habitat. Where possible, vegetation will be left to follow its natural course of succession and will not receive any form of active management. The ultimate goal will be to re-establish, or preserve, a self-sustaining ecosystem.

\subsection{Active Recreation}

Active recreation, including mountain biking, horseback riding, rock climbing, paintball, hunting, and fishing, will be prohibited.

\subsection{Scientific Research}

Non-destructive scientific study and research will be permitted with prior, written approval from the City's Natural Resources Program. A condition of approval will be that the applicant provides the City with a written report of the findings of the study. This will assist the City in compiling a detailed inventory of natural and biological resources located in RCNR.

\section{Conservation Plan}

\subsection{Naming}

The name Reservoir Canyon Natural Reserve shall be the name of the plan area. Since the property combines multiple, contiguous open spaces, including Reservoir Canyon and Bowden Ranch, it is a "natural reserve," according to the City's Open Space Regulations (Municipal Code Sec. 12.22.030).

\subsection{Land Use Designations}

The land uses of Reservoir Canyon Natural Reserve are explained below and illustrated in Figure 7.

4.2.1 Habitat Area - Land on which the primary objective will be to protect natural resources essential to the continued existence of native plants and resident and migratory wildlife. This is by far the largest share of the land uses in RCNR. 


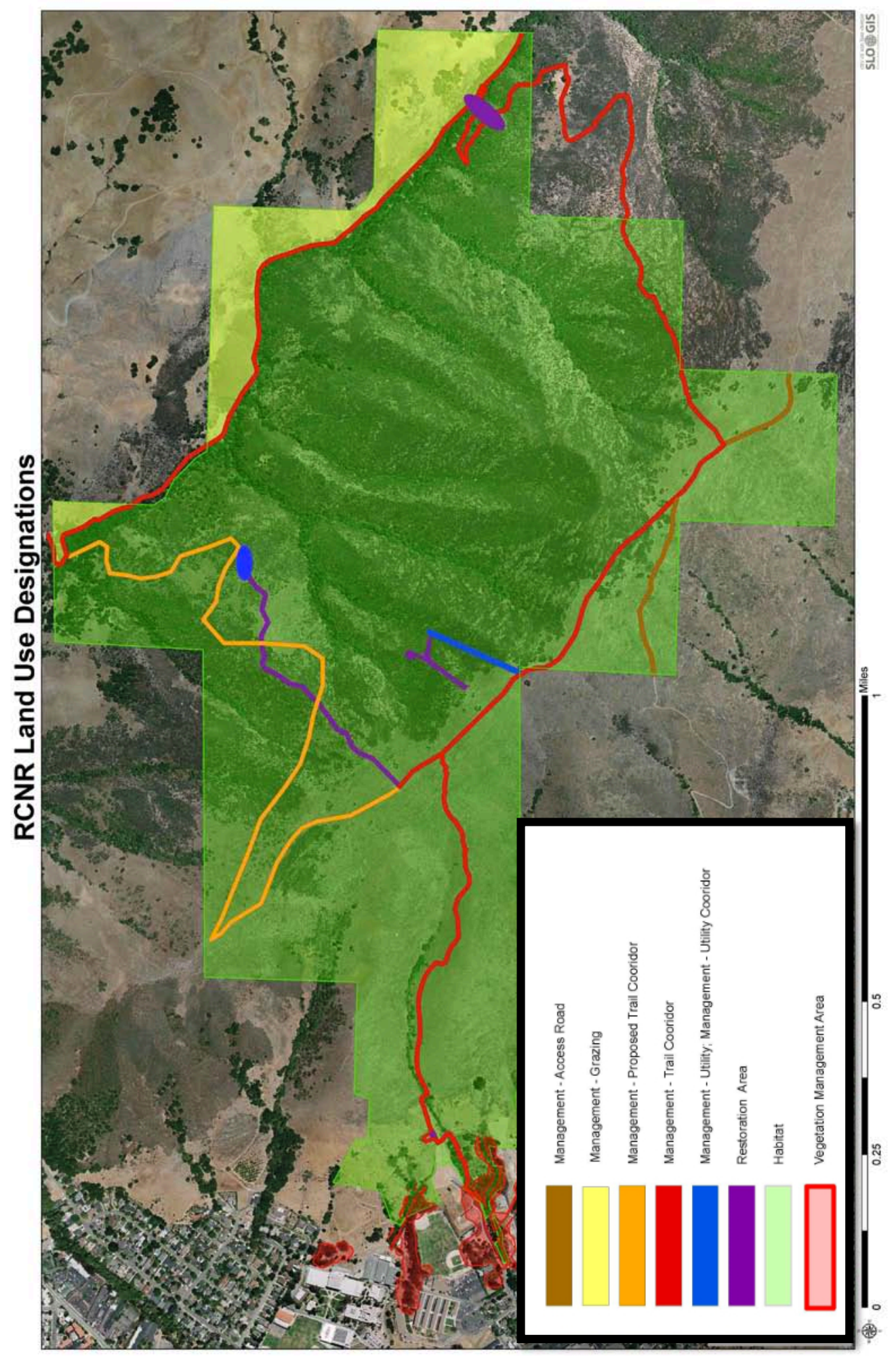

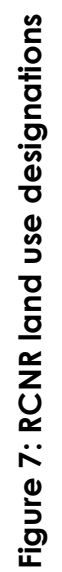




\subsubsection{Management Areas}

a. Trail Corridor - Lands that have the potential to support low levels of recreational pressure; or those areas that may be impacted by adjacent land uses. Active management of land in these areas will be required to facilitate approved activities while protecting valuable natural resources. To provide a safe and stable surface that minimizes soil disturbance, boardwalks will be considered along the lower portion of the trail adjacent to the creek, past the Reservoir Canyon entrance.

b. Proposed Trail Corridor - Proposed expansion of the trail system to complete a loop trail. The alignment proposed is based on interpretation of aerial photographs and contour maps. Actual alignment of the trail may vary depending on ground truth. Currently, both PG\&E and members of the public traverse the steep hillside, passing through habitat. Since the public traverses the area, and PG\&E has a continual need to access its utility towers, the City will examine the feasibility of creating a proper trail to link the ridge back down to the parking lot on the north side of the property. The proposed trail would be intended to both increase safety for visitors and reduce the ongoing impact to the habitat of the current off-trail travel. Therefore, the trail would not exceed a slope of $15 \%$.

c. Utility Corridor - Access trail for PG\&E's maintenance of utility towers. PG\&E has an easement right for such access. A flat area will be considered for use as a heli-spot to provide PG\&E quick maintenance access that minimizes land disturbance.

d. Administrative-Road - Vehicular access road through the southern part of the property. This area will be managed as the trail corridor.

e. Grazing - Land that will be monitored for impacts due to grazing. Based on a 1911 deed, the neighboring property to the north has access rights for watering 40 head of livestock in the creek. [See Appendix $C$ for the text of the deed.] The City will monitor any impacts to this area and consider whether to add fencing along the property line to prevent livestock access.

f. Fire hazard management areas - Areas of active fire hazard mitigation. See Section 5 - Wildfire Preparedness Plan - for additional explanation.

4.2.3 Restoration Area - Land on which restoration and enhancement of plant and animal habitats will be pursued in an effort to restore damaged or impacted natural resources. One restoration area is a gully at the final creek crossing on the Reservoir Canyon side. The other restoration area is the PG\&E maintenance easement. The City is working collaboratively with PG\&E on new practices to satisfy the needs of both parties - that is, to provide safe maintenance access in a sustainable manner. Historically, the utility company clear-cut their way to their towers. Modern practices can achieve the same result with a lower, more sustainable impact.

\subsection{Photo Monitoring Points}

City staff will establish photo-monitoring points throughout RCNR to establish baseline conditions and periodically observe changes. Photo points will include areas of heavy public traffic, areas likely to suffer erosion damage, areas impacted by grazing, and habitats with sensitive plant and wildlife species.

The following photo points will be used to establish baseline conditions. Additional points may be added as necessary if conditions change or new issues arise. Initial photos are included in Appendix G.

Beginning from the Reservoir Canyon (i.e. north) entrance of RCNR:

1. The Reservoir Canyon trailhead

2. The waterfall area near the trailhead

3. Initial creek crossings (two locations)

4. Erosion location 1 - along the trail, after the first two creek crossings

5. Erosion location 2 - farther along the trail

6. Upper creek crossing - final creek crossing before ascending the trail up the ridge

7. Erosional gully along the trail, after the final creek crossing (two locations)

8. PG\&E access trail from the top of the ridge, under the power lines (two locations)

9. Access trail to lower towers proposed for decommissioning

10. Proposed heli-spot for PG\&E maintenance access 
Beginning from the Bowden Ranch (i.e. west) entrance to RCNR on Lizzie Street:

11. The Bowden Ranch trailhead

12. Initial creek crossing

13. Trail through lower entrance area of Bowden Ranch (two locations)

\subsection{Needs Analysis}

\subsubsection{Resource Management and Protection}

Biological surveys are the basis for natural resource management in RCNR. After the initial surveys conducted for the creation of this plan, the City will monitor and protect the habitat areas, and sensitive species identified in particular (e.g. trout, bog thistle, and lilies), on an ongoing basis. City staff will work with local universities to compile ongoing resource inventories.

\subsubsection{Resource Enhancement}

Enhancement of natural resources will focus on two areas of RCNR. The first is the set of utility easement trails for power line maintenance in the northern part of the property. The second is to review and, if necessary, improve the conditions of eroded areas along the creek and trail. In all cases, any enhancements will attempt to restore the area to more natural conditions, weighing trail maintenance or rerouting against existing use. Ongoing management will consist of monitoring and protecting those restored conditions, including removal of non-native vegetation. It will also consist of evaluating the need and feasibility of constructing boardwalks and/or step-over bridges where feasible along the lower, creek-adjacent portion of the trail.

\subsubsection{Mitigation}

RCNR is not conducive to mitigation banking due to its rugged, natural terrain that will largely be left in a natural state except for periodic monitoring to ensure protection. PG\&E's power line upgrade project will include mitigation for impacts to the property within that project's footprint.

\subsubsection{Signage}

Signage for RCNR is currently outdated compared to the standards used for the City's other open spaces, and should therefore be upgraded. City staff will pursue grants or use approved city funds to:

- Highlight features at the trailheads. These will include trail maps and interpretive materials.

- Raise awareness. New signage will be placed at appropriate points along the trail to raise awareness of private property ownership. Specifically, signs will be placed at either end of the trail easement through the Sheffer property. Signs will also be placed at the northwest side of the RCNR property to warn against mountain biking and trespassing on the neighboring private property. Similarly, a sign will be placed at the first creek crossing near the Bowden Ranch trailhead to educate the public that biking is not allowed.

\subsubsection{Trail Loop}

City staff have identified a potential loop system to prevent off-trail travel by the public, which is already occurring. The loop trail would also be a collaborative effort with PG\&E to improve access to utility towers. The new trail corridor would be installed with sustainable techniques, working with the natural contour and integrating gentle grades where possible. The corridor would be integrated with a new PG\&E access path to access the lower tower. The existing access path will be abandoned and rehabilitated in the future.

\subsubsection{Reservoir Canyon Trailhead Area}

a. Fencing - Based on the 1911 agreement to provide water access for livestock from the neighboring private property, the City will monitor and consider the impacts of this continued access over a period of 4-5 years. After evaluating the potential impact, the City will consider the option of using fencing on the property line. Consideration will be based on the extent of impacts and resource availability, particularly given the costs of building fences and for engineering a solution to make water available to the livestock on the neighboring property as would be required per the above agreement. 
b. Improved Creek Crossings - At the easternmost point where the trail crosses Reservoir Canyon Creek, the City will improve signage to identify the trail and allow for safer crossing. The City will also improve crossing opportunities at this point of the creek by constructing a new bridge. For the lower creek crossings, the City will evaluate whether to install boardwalks and/or bridges that provide greater trail access for a longer timeframe, such as during winter storm events when Reservoir Canyon creek often floods parts of the trail. The City will consider as an alternative closing sections of the trail at certain times, particularly during winter storm events.

\subsubsection{Bowden Ranch Trailhead Area}

Significant improvements to the Bowden Ranch trailhead area around Lizzie Street were already made, as required for the Bowden Ranch development. These included planting of native species, improved access at the trailhead, and fencing to guide the public through the riparian area past the trailhead entrance and to avoid off-trail travel to protect sensitive plants. 


\section{Wildfire Preparedness Plan}

Wildfires have occurred periodically in and around Reservoir Canyon and are a continual hazard. The last major fire in the canyon itself was the Las Pilitas fire in July of 1985, which burned a total of 75,000 acres in San Luis Obispo County. More recent major wildfires in the County include the Highway 41 (1994) and Highway 58 (1996) fires; the first of which nearly reached the City of San Luis Obispo.

Although RCNR is property owned by the City of San Luis Obispo, it is located in the County's jurisdiction. Furthermore, for firefighting purposes, most of the land is in the State Responsibility Area (See map in Appendix H). In its Fire Protection Plan, the County has identified the Reservoir Canyon wildland-urban interface in general as target area for focusing fire prevention areas and fuel treatments. The City's area of responsibility includes a portion of the wildland-urban boundary and contains small eucalyptus groves near the Bowden Ranch entrance to RCNR.

Figure 8 shows the fire hazard mitigation areas designated specifically for this conservation plan. The High Hazard areas are at the wildland-urban interface near Bowden Ranch. On City property in RCNR, the highest priority and preference will be to use non-mechanical firefighting methods. This is due to the need to protect the natural habitats and to the relatively lower fire hazard posed by the grassy hillside.

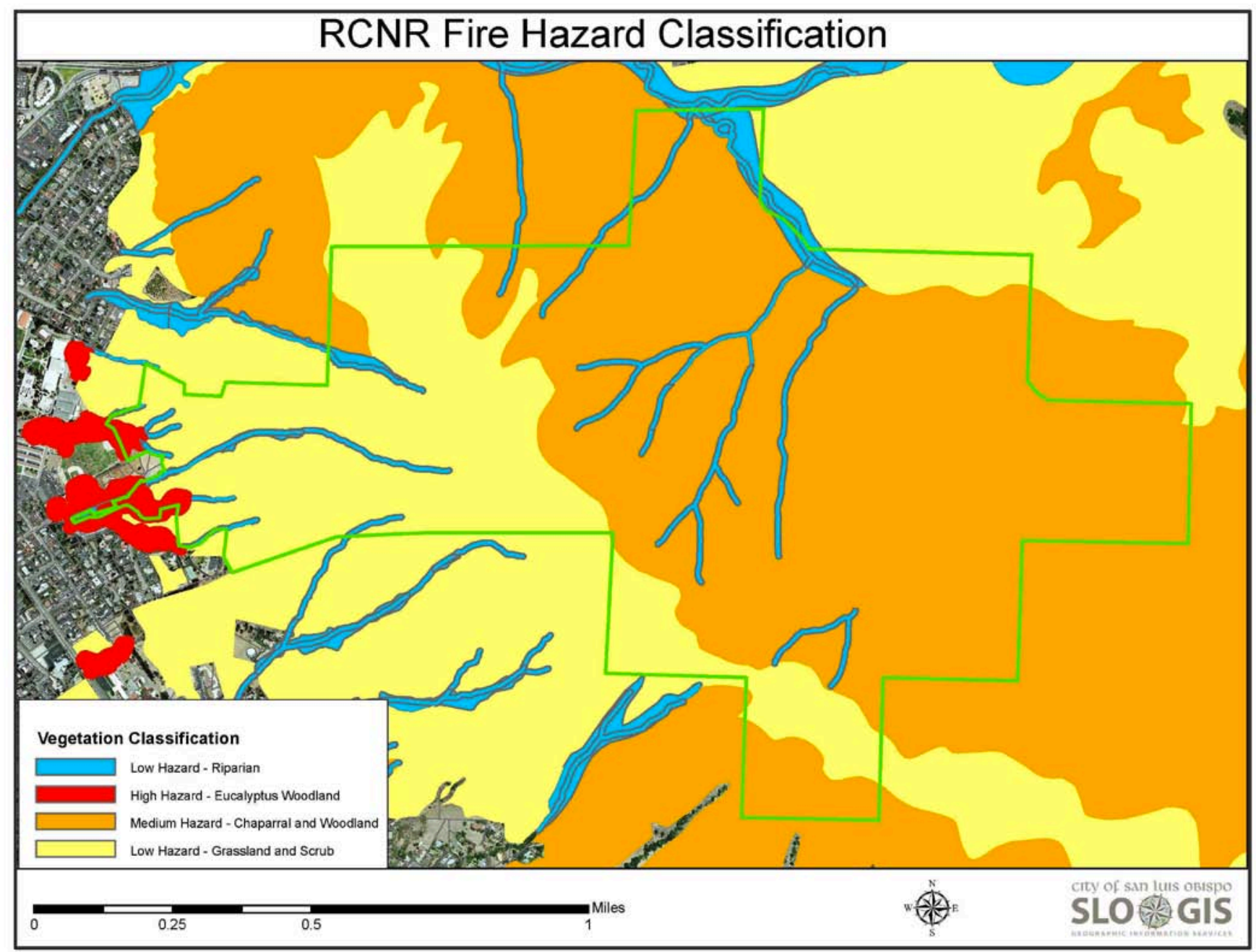

Figure 8: RCNR fire hazard classification. Classification based on vegetation type. 

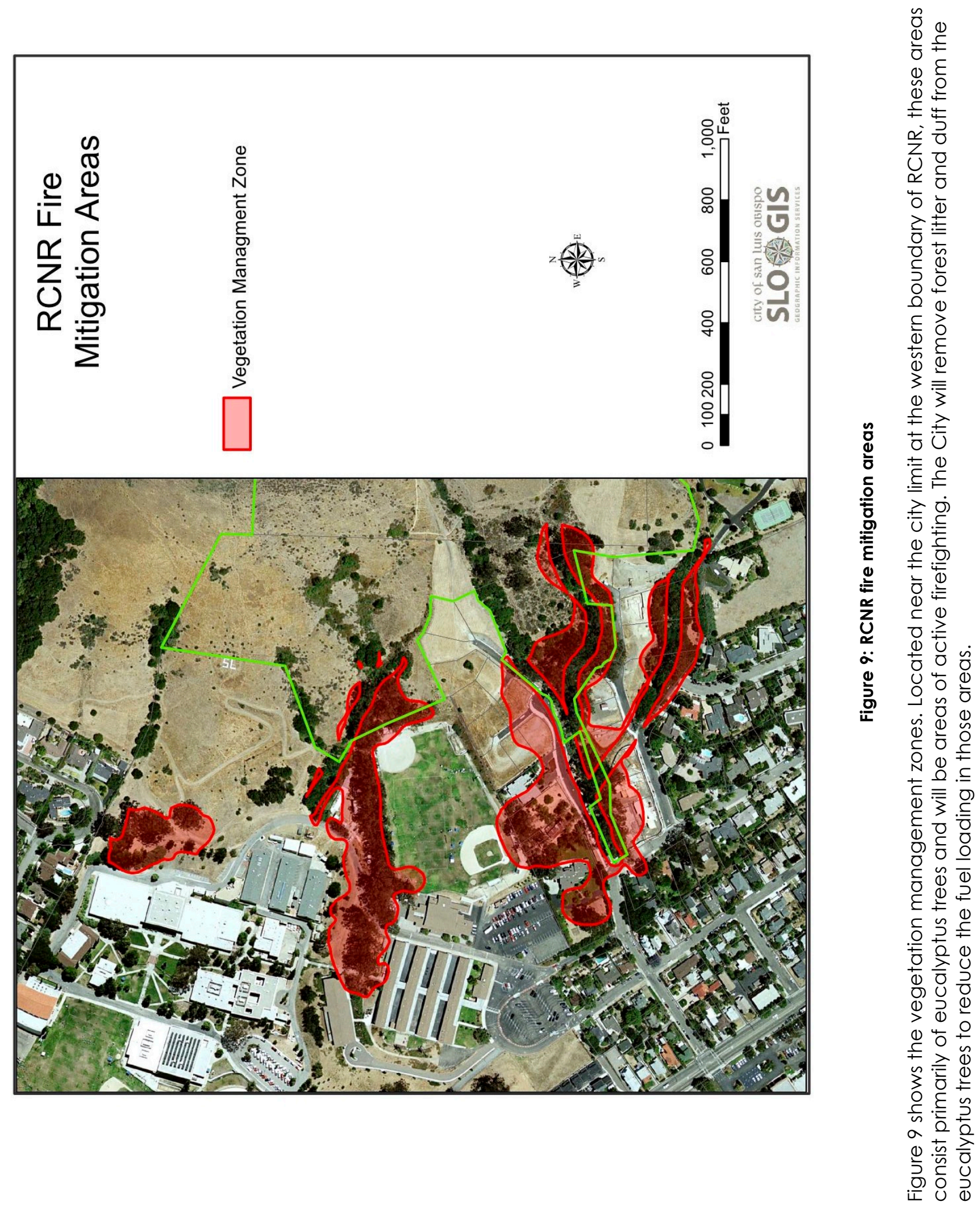


\section{Implementation}

General maintenance activities in accordance with the adopted policies described in "Conservation Guidelines for Open Space Lands of the City of San Luis Obispo" and the "Conservation \& Open Space Element" shall be implemented on a regular or 'as needed' basis

Specific Tasks

Years 1-2

- Monitor impacts to the habitat and trail areas.

- Identify photo-monitoring points.

- Verify the locations of Chorro Creek bog thistle populations.

- Install new, updated signage at trailheads.

- Install signage where the trail crosses private property to denote the private property and educate the public.

- Identify a loop trail alignment.

- Identify a potential section for a boardwalk along the lower portion of the trail near the creek, and construct trial sections to assess effectiveness.

- Work with neighboring landowner near the north RCNR entrance on a grazing schedule for cattle. Monitor the number of head and impacts on RCNR property.

Years 3-5

- Determine whether fencing should be added in strategic locations to prevent cattle from entering RCNR property.

- Construct loop trail based on an alignment identified to minimize impacts.

- Evaluate boardwalk trial sections and, if the trial is successful, complete construction of the boardwalk.

- Conduct another comprehensive field analysis to determine changes in species composition, paying close attention to threatened/endangered species, wildlife corridors, and levels of invasive plants.

Year 6-

- Reassess the locations of photo-monitoring points to guide future management based on use.

Ongoing Specific Tasks

- Work with local universities to compile resource inventories.

- Monitor ecosystem health.

- Monitor integrity of the "Cal Poly" bridge and reinforce if necessary.

- Monitor non-native vegetation and remove.

- Monitor Chorro Creek bog thistle location(s) to ensure protection.

\section{Fiscal Statement}

City staff will develop a Capital Improvement Plan (CIP) program for RCNR's trail improvements. The program would include signage, trail work, and bridge and boardwalk construction to allow more public access and safer passage through the property. There is an opportunity to work collaboratively with PG\&E to fund and implement some of the projects described in this plan. City staff will also pursue grants to augment funding for this plan's identified projects.

\section{Amendment}

This Conservation Plan, or any portion of it, may be considered for amendment upon request. Any citizen or other interested party may initiate such a request, however such requests shall be directed to the City Administrative Officer or designee. Such a request will include the nature of the requested amendment and rationale for the request. If appropriate, the amendment will be processed in the same manner as the original Conservation Plan. 


\section{Appendix A: Proposed Reservoir Canyon Master Plan (1980's Cal Poly Student Project)}

The following are selected images from the 1981 master plan created by Cal Poly landscape architecture students. Clockwise from left: A. Boulder bridge for creek crossing; B. Paved parking area with pond near Reservoir Canyon entrance; Concept map with loop trail extension (dotted line near "finger canyon" area.

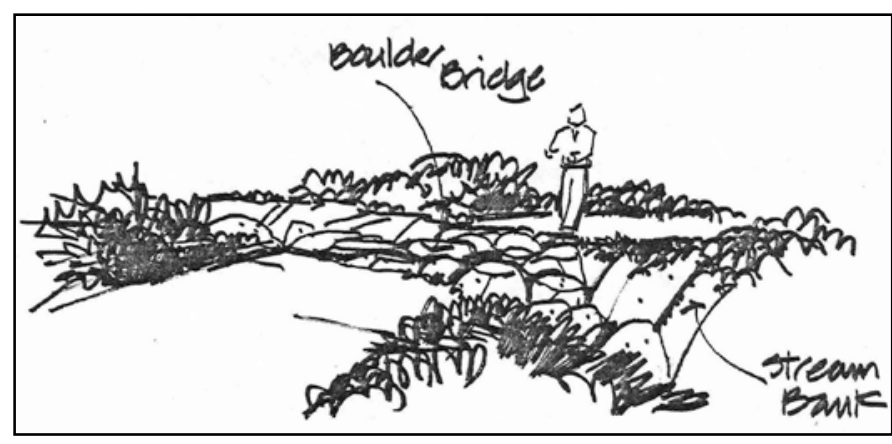

A. Boulder Bridge

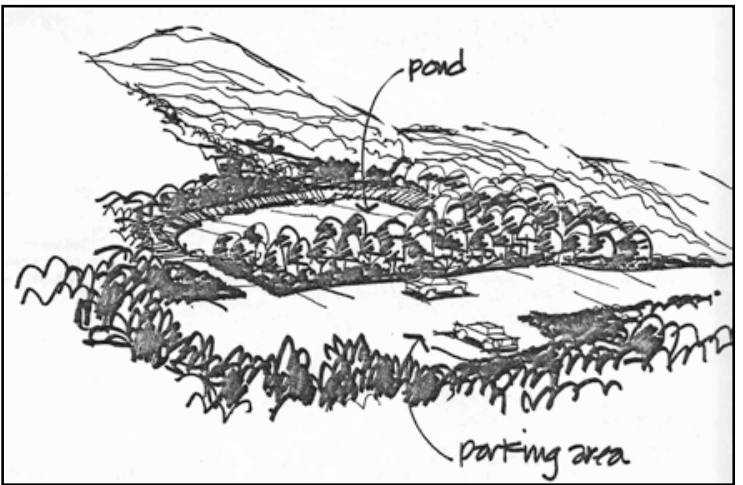

B. Parking Area \& Pond

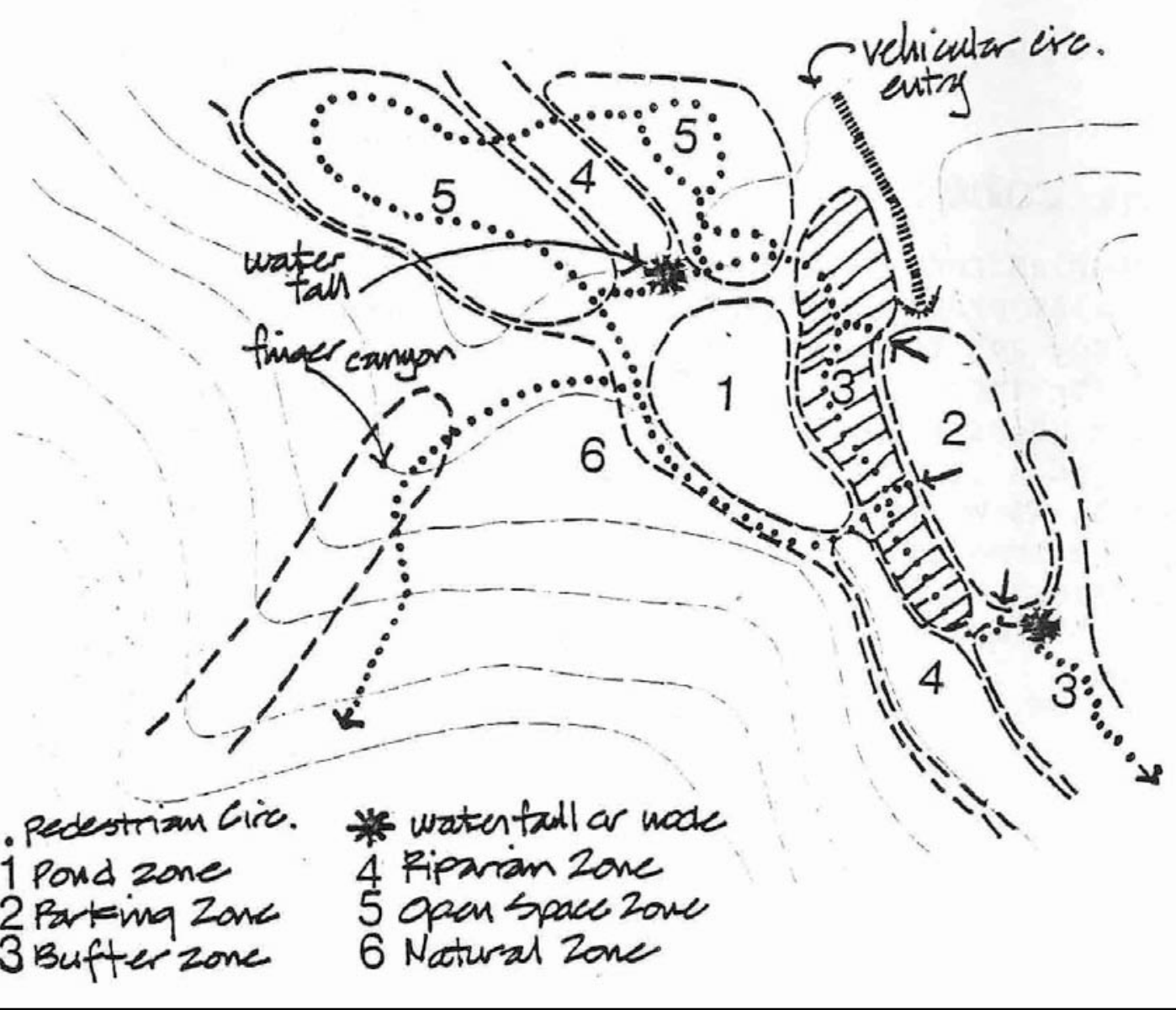

C. Concept Map 


\section{Appendix B: Hastings Trail Easement Deed and Transcript}

ve. 722 PAG 438

GRANT DEED

FOR A VALUABLE CONSIDERATION, rocolpt of wh1oh 1s horoby acknow iod god,

EDTARD J. HASTINGS, a widowar

hereby GRANTS to

FRANK D. HASTINGS, alngle man.

the following doscribod roal proverty in the state of Callfornia, county of San Lu1s Obisdo,

The nor thesat quarter of the northosat auarter of Soction 31 in Townsh10 30 South, Ranko 13 East, Mount Dlablo Baso and Moridian, in tho county of San Luls oblspo, socordins to the orricial plat of the survoy of sald land on f110 in tho Buroau of Land Manarement.

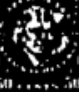

Excoptinf therofrom all the coul and othor minorals in tho

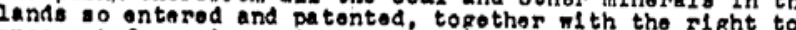
prospoot for, mino and roreve the anmo pursuent to the

prov1alons and 11mitations of tho Act of Docombor 29,1916 (39 stat. 362 ) as roseryod by tho Unitod States of Amorien In patent rocordod Mny 8, 1930 in book $X$, oage 496 of patonts.

Also oxcootinn and rasorvine unto the orantor horoln an ongmont for road purdoses ovor and across said land, at sito and location to bo solocted by or accoptablo to tho frantor and his holrs and assipns and sald oasomont to bo of a midth of not more than 50 foot. Sald osement sheil inure to the baniflt of the holrs ond a Intendod to bo used by and to bonofit tho omnors of any of tho lands or port dons and the the that the lands so ratalnod or the nortions of sald lands can bo heid and onjojod and tho easoment for road ourvoses be wad and ongoyod whout limit for any oartioular use by tho hrantor and his hoirs and asters and the holders, swors and usors of sald oasement.

Datnd: June 9, 1953

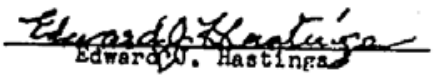

STATE OF CALIFOPRIA) ss.
COUNTY OP ALALEDA ;

On July $155^{4}$, 195

- Notary Publio in end for 1953 boforo mo, tho undorslaned, appoarod Edward J. Hastinga knom to mo to bo to, porsonali

hoso name is oubsorlbod to the within instrumont and acknomfavis.
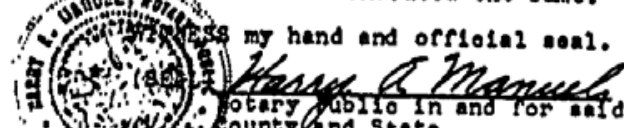

Fisys sounty hand stato.

orinit co.

11038

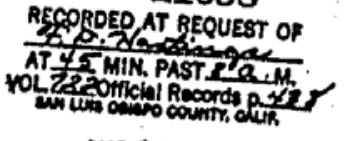

AUG 181953
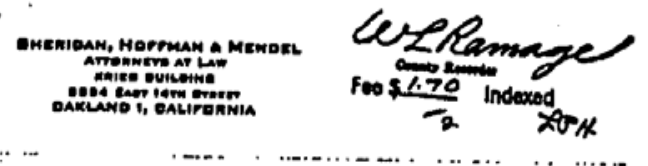


\title{
[Transcription of Hastings Property Trail Easement]
}

\author{
GRANT DEED
}

FOR A VALUABLE CONSIDERATION, receipt of which is hereby acknowledged,

EDWARD J. HASTINGS, a widower

hereby GRANTS to

FRANK D. HASTINGS, a single man

the following described real property in the state of California, county of San Luis Obispo,

The northeast quarter of the northeast quarter of Section 31 in Township 30 South, Range 13 East, Mount Diablo Base and Meridian, in the county of San Luis Obispo, according to the official plot of the survey of said land on file in the Bureau of Land Management.

Excepting therefrom all the coal and other minerals in the lands so entered and patented, together with the right to prospect for, mine and remove the same pursuant to the provisions and limitations of the Act of December 29, 1916 (39 Stat. 862) as reserved by the United States of America in patent recorded May 8,1930 , in book K, page 496 of Patents.

Also excepting and preserving unto the grantor herein an easement for road purposes over and across said land, at a site and location selected by or acceptable to the Grantor and his heirs and assigns and said easement to be a width of not more than 50 feet. Said easement shall inure to the benefit of the heirs and assigns of the Grantor and is intended to be used by and to benefit the owners of the any of the lands or portions thereof retained by the Grantor so that the lands so retained or portions of said lands can be held and enjoyed and the easement for road purposes be used and enjoyed without limit for any particular use by the Grantor and his heirs and assigns and the holders, owners and users of said easement.

Dated: June 9, 1953

(signed)

Edward J. Hastings

[Notarized on July $15^{\text {th }}, 1953$ by

Harry A. Manuel, notary public

State of California

County of Alameda]

RECORDED AT REQUEST OF

(signed) F. D. Hastings

AT 45 MIN. PAST 8 A.M.

VOL. 722 Official Records P. 488

SAN LUIS OBISPO COUNTY, CALIF.

AUG. 18, 1953

(signed) W. L. Ramage

County Recorder 


\section{Appendix C: Trutio Deed}

The following is the April 29, 1911 deed for the Trutio property northeast of RCNR, which includes the following passage that requires the City of San Luis Obispo to provide sufficient water for 40 head of livestock to the Trutio property. A scanned image of the full record on the City's books is included on subsequent pages.

"...said parties of the first part [S. Jackson Lowe and Robert L. Lowe] also give and grant unto said party of the second part [the City of San Luis Obispo] the perpetual right of way and easement to enter upon their said lands situate as above described for the purposes of cleaning out and keeping clean the channel of what is known as the upper reservoir or Fillmore Creek and the branches thereof. As a further consideration for this conveyance, said party of the second part agrees to pipe by means of 1 inch pipe to a trough to be located on the Northwest quarter of the southeast quarter of said Section Thirty, so long as said 40 acres of land remains unfenced, and thereafter on the Northeast quarter of said Section Thirty, and to supply thereat sufficient water to water not to exceed forty head of stock; provided that the said parties of the first part shall furnish the necessary trough and float valve faucets to prevent the waste of water, and provided, that said City shall not be required to furnish in excess of 5000 feet of pipe, and that said parties of the first part shall at all times maintain said trough and float valve faucets and pipe line in good order and condition. To have and to hold, the said property, rights and easements unto said party of the second part, its successors and assigns, forever."

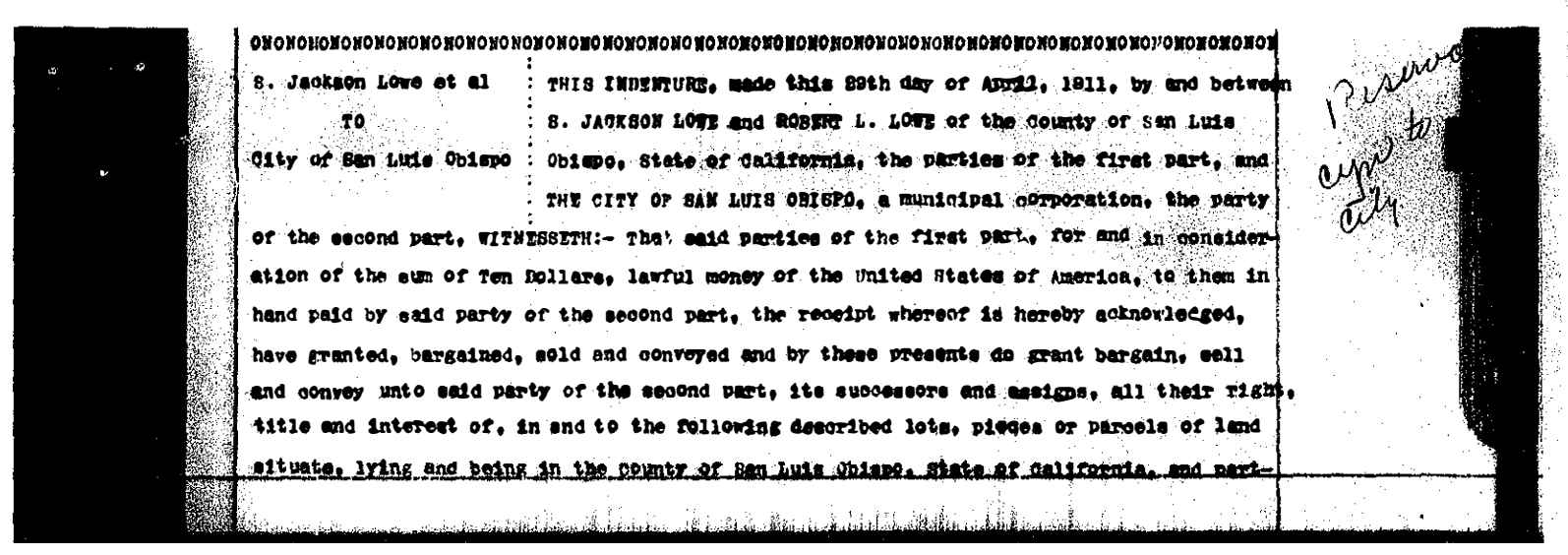




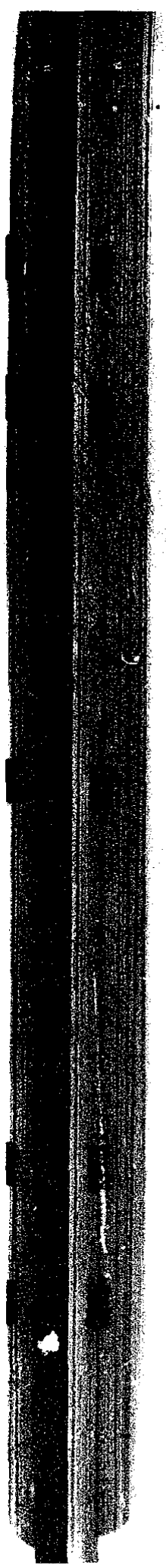

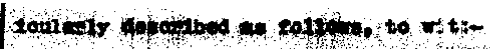

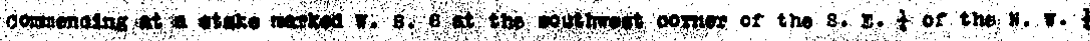

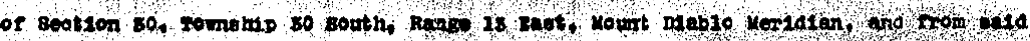

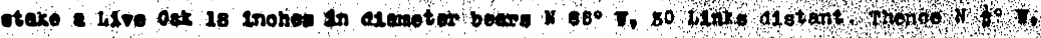

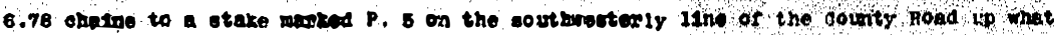

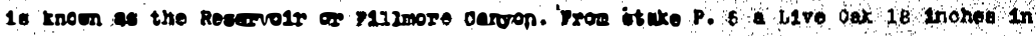

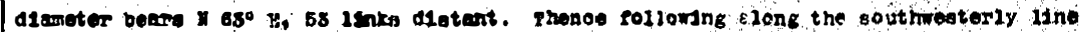
of sadd foad on the sollowing onumaes and dlettroes, to vat!

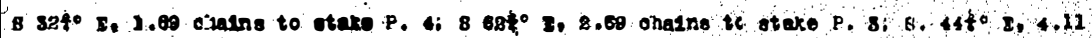

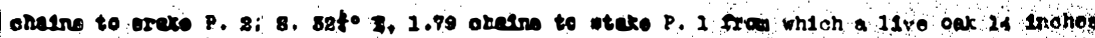

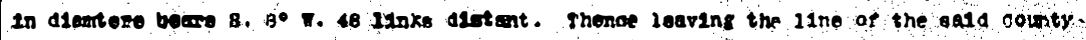

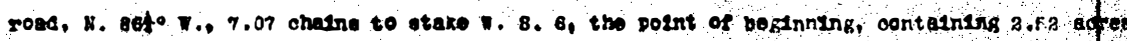

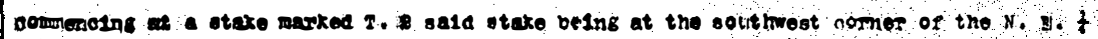

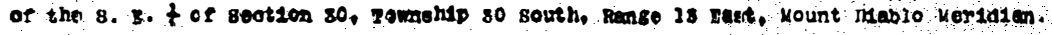

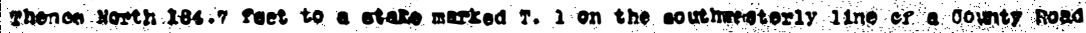

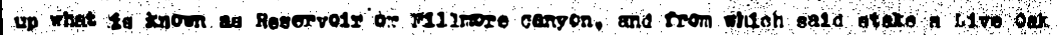

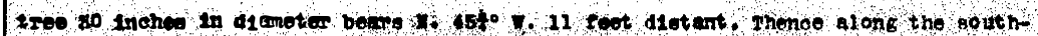

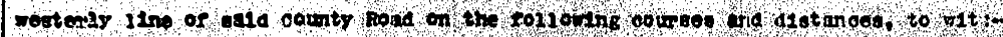

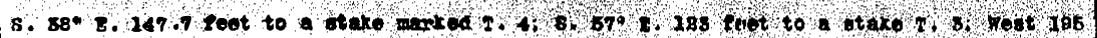
feet to atake T. 2, the point of beginning, contalining s7/100 aores sald part $10 \mathrm{~B}$ of the

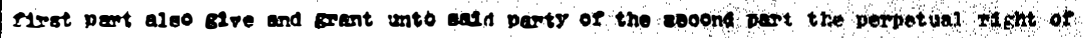

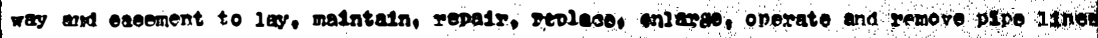
for the tranoportation af water orer, along and acrogs tho oninty road in what 18 knom

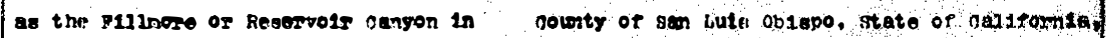
where the sawe crosses the lands of tho partion of the frot part, situste in seotsono.

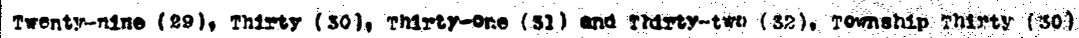

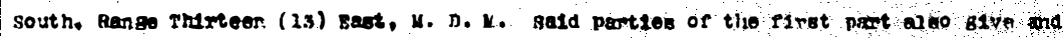

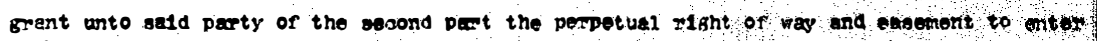
upon the1r soth lands: situate as above cosersbed for the pun of cleandns out and keap

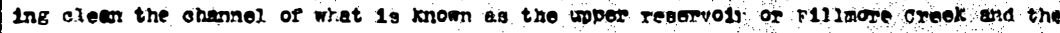

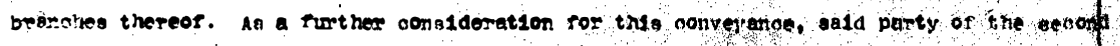

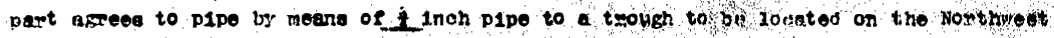
quantor of the southeast nuarte- of alc section mistty $(30)$ so lons as eatd 40 acrog of

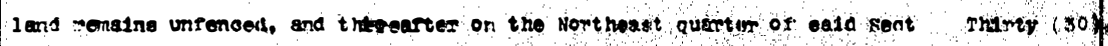

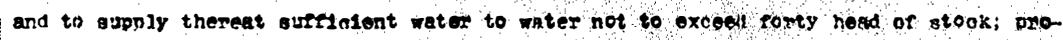

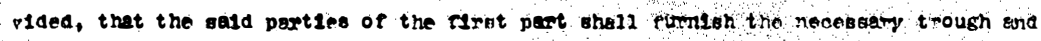
flost valve paucets to prevent the waste of water, ard povided, that ocil ofty orisl not

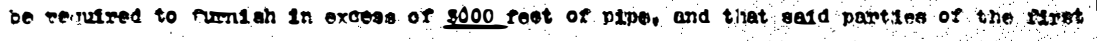

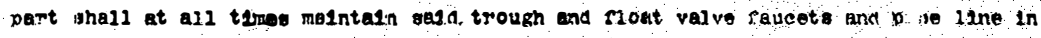
good srder and so dition. To have sid to hold, the aas pesperty. righto und easments

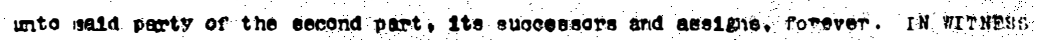

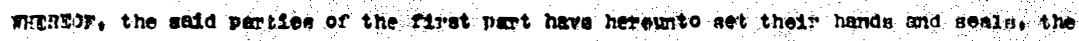

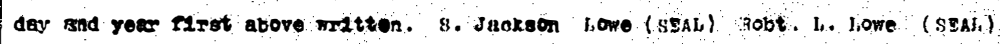

BTATE OF CALTFORKIA, colonty of gen luss oblepo. , SS.

on thin Jath das of A ursust, 1811 , before mo.

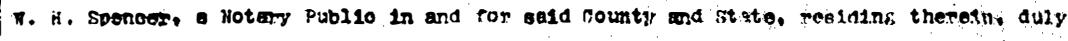

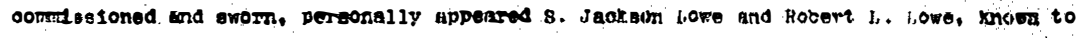

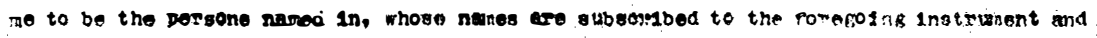

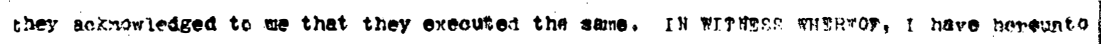

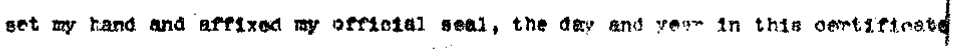

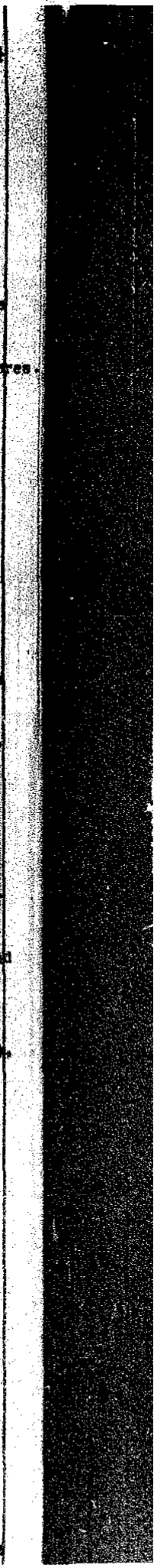




\section{Appendix D: Soils of Reservoir Canyon Natural Reserve}

\section{Table 2: USGS Soil Survey - Reservoir Canyon Area}

\begin{tabular}{|c|c|c|c|}
\hline \multicolumn{3}{|c|}{ Source: USGS Web Soil Survey - San Luis Obispo County, California, Coastal Part } \\
\hline Map unit symbol & Map unit name & Acres in AOI & Percent of AOI \\
\hline 121 & Concepcion loam, 5 to 9 percent slopes & 0.8 & $0.00 \%$ \\
\hline 130 & Diablo and Cibo clays, 9 to I5 percent slopes & 0.1 & $0.00 \%$ \\
\hline 142 & Gaviota fine sandy loam, 15 to 50 percent slopes & 33.6 & $1.40 \%$ \\
\hline 143 & Gazos-Lodo clay loams, I5 to 30 percent slopes & 55.9 & $2.40 \%$ \\
\hline 145 & Gazos-Lodo clay loams, 50 to 75 percent slopes & 55.3 & $2.40 \%$ \\
\hline 160 & Los Osos loam, I5 to 30 percent slopes & 75.9 & $3.20 \%$ \\
\hline 161 & Los Osos loam, 30 to 50 percent slopes & 38.4 & $1.60 \%$ \\
\hline 162 & Los Osos-Diablo complex, 5 to 9 percent slopes & 3.5 & $0.20 \%$ \\
\hline 163 & Los Osos-Diablo complex, 9 to 15 percent slopes & 18.7 & $0.80 \%$ \\
\hline 164 & Los Osos-Diablo complex, 15 to 30 percent slopes & 30.1 & $1.30 \%$ \\
\hline 165 & Los Osos-Diablo complex, 30 to 50 percent slopes & 148.3 & $6.30 \%$ \\
\hline 183 & Obispo-Rock outcrop complex, 15 to 75 percent & $1,839.00$ & $78.40 \%$ \\
\hline 194 & & 22.6 & $1.00 \%$ \\
\hline 197 & slopes & 0.1 & $0.00 \%$ \\
\hline 203 & Salinas silty clay loam, 0 to 2 percent slopes & 23.9 & $1.00 \%$ \\
\hline
\end{tabular}

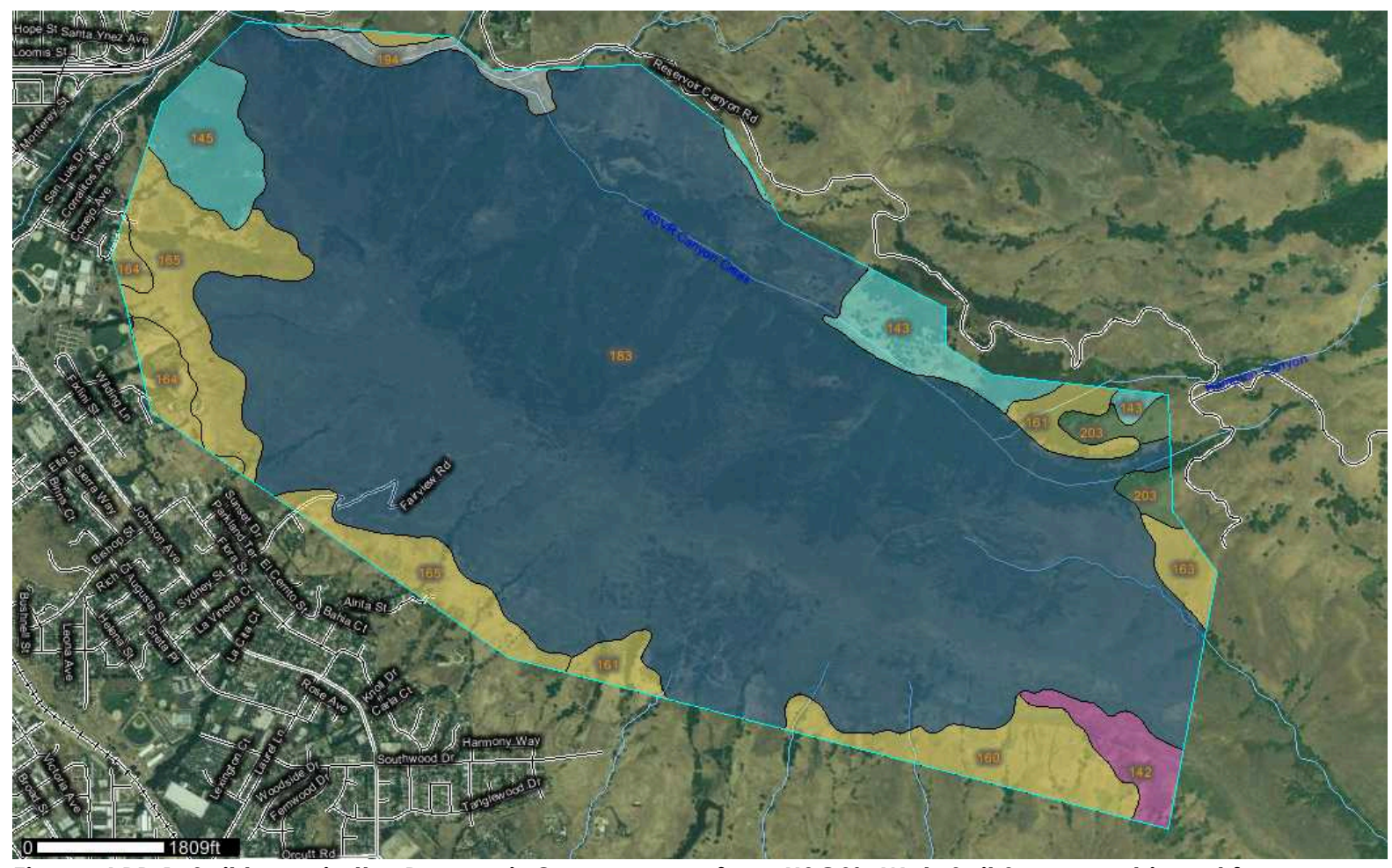

Figure APP 1: Soil types in the Reservoir Canyon area from USGS's Web Soil Survey, retrieved from http://websoilsurvey.nrcs.usda.gov/app/HomePage.htm 


\section{Appendix E: Plants}

\section{Plants}

Except where noted the plants listed below are from the 2002 survey by Ben Carter, for his Cal Poly senior project.

\begin{tabular}{|c|c|c|}
\hline \multicolumn{3}{|c|}{ PLANT LIST } \\
\hline Scientific Name & Family & Common Name \\
\hline Achillea millefolium & Asteraceae & Common Yarrow \\
\hline Adenostoma fasciculatum & Rosaceae & Chamise \\
\hline Adiantum jordanii & Pteridaceae & Maidenhair fern \\
\hline Aquilegia eximia & Ranunculaceae & Columbine \\
\hline Artemisia californica & Asteraceae & California sagebrush \\
\hline Artemisia douglasiana & Asteraceae & Mugwort \\
\hline Astragalus curtipes & Fabaceae & Locoweed \\
\hline Astragalus gambelianus & Fabaceae & Gambel's Locoweed \\
\hline Avena barbata & Poaceae & Slender wild oats \\
\hline Bloomeria crocea & Liliaceae & Common goldenstar \\
\hline Brachypodium distachyon & Poaceae & False brome \\
\hline Bromus carinatus & Poaceae & California brome \\
\hline Bromus hordeaceus & Poaceae & Soft chess brome \\
\hline Bromus madritensus ssp. rubens & Poaceae & Red brome \\
\hline Calochortus clavatus var. clavatus* & Liliaceae & Club-haired Mariposa lily \\
\hline Calochortus obispoensis* & Liliaceae & $\begin{array}{l}\text { San Luis Obispo Mariposa } \\
\text { lily }\end{array}$ \\
\hline Calystegia macrostegia & Convolvulaceae & Wild morning glory \\
\hline Cardamine californica ssp. integrifolia & Brassicaceae & Milkmaids \\
\hline Carduus pycnocephalus & Asteraceae & Italian thistle \\
\hline Castilleja affinis * & Scrophulariaceae & Indian paintbrush \\
\hline Castilleja densiflora ssp. obispoense & Scrophulariaceae & Owl's clover \\
\hline Ceanothus cuneatus & Rhamnaceae & Buckbrush \\
\hline Cercocarpus betuloides & Rosaceae & Mountain mahogany \\
\hline $\begin{array}{l}\text { Chlorogal/um pomeridianum var. } \\
\text { pomeridianum }\end{array}$ & Liliaceae & Soap plant \\
\hline Chorizanthe breweri * & Polygonaceae & Brewer's spineflower \\
\hline Chorizanthe palmeri * & Polygonaceae & Palmer's spineflower \\
\hline Cirsium fontinale var. obispoense $\wedge$ & Asteraceae & Chorro Creek bog thistle \\
\hline Clarkia purpurea & Onagraceae & Farewell to spring \\
\hline Claytonia perfoliata & Portulaceae & Miner's lettuce \\
\hline Coreopsis douglasii & Asteraceae & Douglas's coreopsis \\
\hline Cortaderia selloana & Poaceae & Pampas grass \\
\hline Crassula connata & Crassulaceae & Pygmy weed \\
\hline Cryptantha clevelandii & Boraginaceae & $\begin{array}{l}\text { Cleveland's popcorn } \\
\text { flower }\end{array}$ \\
\hline Cryptantha muricata & Boraginaceae & Popcorn flower \\
\hline Daucus pusillus & Apiaceae & $\begin{array}{l}\text { Miniature Queen Anne's } \\
\text { lace }\end{array}$ \\
\hline Delphinium parryi ssp. eastwoodiae & Ranunculaceae & Parry's delphinium \\
\hline
\end{tabular}


DRAFT Reservoir Canyon Conservation Plan

\begin{tabular}{|c|c|c|}
\hline Scientific Name & Family & Common Name \\
\hline Dendromecon rigida & Papaveraceae & Bush poppy \\
\hline Dichelostemma capitatum ssp. capitatum & Liliaceae & Blue dicks \\
\hline Dodecatheon clevelandii & Primulaceae & Shooting stars \\
\hline Dudleya abramsii ssp. Murina* & Crassulaceae & San Luis Obispo dudleya \\
\hline Dudleya lanceolata* & Crassulaceae & Lanceleaf dudleya \\
\hline Elymus elymoides & Poaceae & Squirreltail \\
\hline Elymus glaucus & Poaceae & Blue wildrye \\
\hline Epilobium minutum & Onagraceae & Threadstem fireweed \\
\hline Eriogonum elongatum var. elongatum & Polygonaceae & Slender buckwheat \\
\hline Eriogonum fasciculatum var. foliolosvm & Polygonaceae & California buckwheat \\
\hline $\begin{array}{l}\text { Eriophyllum confertiflorum var. } \\
\text { confertiflorum }\end{array}$ & Asteraceae & Golden yarrow \\
\hline Erodium cicutarium & Geraniaceae & Redstem filaree \\
\hline Eschscholzia califomica & Papaveraceae & California poppy \\
\hline Eucalyptus globulus \# & Myrtaceae & Blue gum eucalyptus \\
\hline $\begin{array}{l}\text { Eucrypta crysanthemifolia var. } \\
\text { chrysanthemifolia }\end{array}$ & Hydrophyllaceae & Common eucrypta \\
\hline Euphorbia spathulata & Euphorbiaceae & Petty spurge \\
\hline Festuca elmeri & Poaceae & Elmer's fescue \\
\hline Filago califomica & Asteraceae & Herba impia \\
\hline Fritillaria biflora var. biflora & Liliaceae & Chocolate bells \\
\hline Galium califomicum & Rubiaceae & California bedstraw \\
\hline Galium porrigens var. porrigens & Rubiaceae & Climbing bedstraw \\
\hline Garrya veatchii & Garryaceae & Silk tassel bush \\
\hline Gilia achilleaefolia & Polemoniaceae & Blve-headed gilia \\
\hline Gnaphalium califomicum & Asteraceae & California everlasting \\
\hline Grindelia hirsutula var. davyii & Asteraceae & Gum plant \\
\hline Guillenia lasiophyla & Brassicaceae & Wild mustard \\
\hline Hazardia squarrosa var. sqarrosa & Asteraceae & Saw-toothed golden bush \\
\hline Hemizonia congesta ssp. Iuzulifolia & Asteraceae & Hayfield tarweed \\
\hline Hesperevax sparsiflora & Asteraceae & Hesperevax \\
\hline Heteromeles arbutifolia & Rosaceae & Toyon \\
\hline Hordeum marinum & Poaceae & Mediterranean barley \\
\hline Hypochaeris glabra & Asteraceae & Smooth cat's-ear \\
\hline Keckiella cordifolia & Scrophulariaceae & Climbing penstemon \\
\hline Koeleria macrantha & Poaceae & June-grass \\
\hline Lactuca saligna & Asteraceae & Slender lettuce \\
\hline Lasthenia califomica & Asteraceae & Goldfields \\
\hline Lathyrus vestitus & Fabaceae & Wild sweet-pea \\
\hline Layia platyg/ossa & Asteraceae & Tidy-tips \\
\hline Lepidium nitidum & Brassicaceae & Pepper cress \\
\hline Lessingia filaginifolia & Asteraceae & California-aster \\
\hline Leymus condensatus & Poaceae & Giant wildrye \\
\hline Linanthus parviflorus & Polemoniaceae & Baby stars \\
\hline Lithophragma heterophyllum & Saxifragaceae & Woodland star \\
\hline Lolium multiflorum & Poaceae & Italian ryegrass \\
\hline Lomatium dasycarpum & Apiaceae & Large-seeded lomatium \\
\hline
\end{tabular}


DRAFT Reservoir Canyon Conservation Plan

\begin{tabular}{|c|c|c|}
\hline Scientific Name & Family & Common Name \\
\hline Lomatium parvifolium * & Apiaceae & Small-leaved lomatium \\
\hline Lomatium utriculatum & Apiaceae & Foothill lomatium \\
\hline Lotus scoparius & Fabaceae & Deer weed \\
\hline Lotus strigosus & Fabaceae & Annual lotus \\
\hline Madia gracilis & Asteraceae & Slender tarweed \\
\hline Melica imperfecta & Poaceae & Melic grass \\
\hline Melica torreyana & Poaceae & Torrey's melic grass \\
\hline Microseris douglasii & Asteraceae & Douglas's microceris \\
\hline Mimulus aurantiacus & Scrophulariaceae & Sticky monkeyflower \\
\hline Mimulus guttatus & Scrophulariaceae & Seep-spring monkeyflower \\
\hline Nassella lepida & Poaceae & Slender needlegrass \\
\hline Nassella pulchra & Poaceae & Purple needlegrass \\
\hline Opuntia ficus-indica & Cactaceae & Prickly pear cactus \\
\hline Orobanche californica & Orobanchaceae & California broom-rape \\
\hline Pellaea andromedifolia & Pteridaceae & Coffee fern \\
\hline Pentagramma triangularis & Pteridaceae & God-back fern \\
\hline Phacelia distans & Hydrophyllaceae & Common phacelia \\
\hline Phacelia imbricata ssp. imbricata & Hydrophyllaceae & Imbricate phacelia \\
\hline Pickeringia montana var. montana & Fabaceae & Chaparral pea \\
\hline Pinus attenuata & Pinaceae & Knobcone pine \\
\hline Plantago erecta & Plantaginaceae & Dwarf plantain \\
\hline Poa secunda & Poaceae & Blvegrass \\
\hline Polypodium californicum & Polypodiaceae & California polypody \\
\hline Prunus ilicifolia ssp. llicifolia & Rosaceae & Holly-leafed cherry \\
\hline Pteridium aquilinum var. pubescens & Dennstaedtiaceae & Bracken fern \\
\hline Pterostegia drymarioides & Polygonaceae & Notchleaf \\
\hline Quercus agrifolia & Fagaceae & Coast live oak \\
\hline Quercus durata & Fagaceae & Leather oak \\
\hline Rafinesquia californica & Asteraceae & California-chicory \\
\hline Ranunculus californicus & Ranunculaceae & California buttercup \\
\hline Rhamnus californica ssp. californica & Rhamnaceae & Coffee-berry \\
\hline Rhamnus crocea & Rhamnaceae & Redberry \\
\hline Ribes speciosum & Grossulariaceae & $\begin{array}{l}\text { Fuschia-flowered } \\
\text { gooseberry }\end{array}$ \\
\hline Rosa californica & Rosaceae & Wild rose \\
\hline Salix breweri & Salicaceae & Brewer's willow \\
\hline Salvia columbariae & Lamiaceae & Chia \\
\hline Salvia mellifera & Lamiaceae & Black sage \\
\hline Sanicula crassicaulis & Apiaceae & Biscuit root \\
\hline Selaginella bigelovii & Selaginaceae & Resurrection plant \\
\hline Scrophularia californica & Scraphulariaceae & Figwort \\
\hline Senecio aphanactis * & Asteraceae & Alkali groundsel \\
\hline Senecio vulgaris & Asteraceae & Common groundsel \\
\hline Silene gallica & Caryophyllaceae & Windmill pink \\
\hline Silene laciniata ssp. major & Caryophyllaceae & Mexican pink \\
\hline Sisyrinchium bellum & Iridaceae & Blue-eyed grass \\
\hline Solanum xanti & Solanaceae & Purple nightshade \\
\hline
\end{tabular}


DRAFT Reservoir Canyon Conservation Plan

\begin{tabular}{|l|l|l|}
\hline Scientific Name & Family & Common Name \\
\hline Sonchus oleraceus & Asteraceae & Common sow thistle \\
\hline Stachys bullata & Lamiaceae & Common hedge nettle \\
\hline Stachys pycnantha & Lamiaceae & Short-spiked hedge nettle \\
\hline Stephanomeria virgata ssp. pleurocarpa & Asteraceae & Wire lettuce \\
\hline Streptanthus albidus ssp. peramoenus & Brassicaceae & Most beautiful jewel flower \\
\hline Symphoricarpos mollis & Caprifoliaceae & Creeping snowberry \\
\hline Thysanocarpus laciniatus & Brassicaceae & Fringepod \\
\hline Toxicodendron diversilobum & Anacardiaceae & Poison oak \\
\hline Trifoliumdepauperatum var. amplectens & Fabaceae & Balloon clover \\
\hline Trifolium fragiferum & Fabaceae & Strawberry clover \\
\hline Trifolium oliganthum & Fabaceae & Common clover \\
\hline Umbellularia californica & Lauraceae & California bay laurel \\
\hline Uropappus lindleyi & Asteraceae & Silver puffs \\
\hline Verbena lasiostachys & Verbenaceae & Vervain \\
\hline Vicia villosa & Fabaceae & Hairy vetch \\
\hline Viola pedunculata & Violaceae & Johnny jump-ups \\
\hline Vulpia microstachys & Poaceae & Annual fescue \\
\hline Yucca whipplei & Liliaceae & Our Lord's candle \\
\hline Zigadenus fremontii & Liliaceae & Death camas \\
\hline
\end{tabular}

* Rare

$\wedge$ Listed as endangered by the U.S. Fish and Wildlife Service:

http://ecos.fws.gov/speciesProfile/profile/speciesProfile.action?spcode=Q1UG

\# From field observations, Oct. 2011-May 2012 


\title{
Appendix F: Notes From January 31, 2012 Initial Public Meeting
}

\author{
Reservoir Canyon Natural Reserve Conservation Plan Initial Public Meeting \\ Jan. 31, 2012 6:30 PM \\ Meeting Notes
}

City Biologist Freddy Otte introduced the Reservoir Canyon Natural Reserve and explained the City's intent to create a conservation plan. The presentation covered the history of the area, prominent natural features, management issues, sensitive plant and animal species, and legal issues.

\begin{abstract}
History
City involvement with the area began around 1900 when a private water company was acquired including 200 acres of land in Reservoir Canyon. By the 1960s, the City discontinued use of the reservoir. In 1994 the area officially became open space. The 284-acre Hastings property and the 207-acre Bowden ranch properties were acquired and added to the Natural Reserve in 2001 and 2006, respectively. Currently (2012), the City is negotiating the purchase of 83 acres at Goldtree tract to be added to the Natural Reserve. The City will concurrently prepare a Conservation Plan.
\end{abstract}

\section{Natural and Cultural Features}

Reservoir Canyon has two main habitats: chaparral north of the ridge and pristine grassland to the south. These are home to several rare plant and animal species. Two perennial creeks and numerous small springs and seeps emanate from the ridge. There is one trail through the property, but no loop. Consideration of whether to create a loop trail will occur in the conservation planning process. Several road/trail easements exist for servicing electrical towers owned by PG\&E.

\section{Management Issues or Concerns}

The conservation plan will address the following issues / concerns:

- Proper restoration of damaged areas (such as the north trailhead area)

- Evaluation of the trail system, including considering whether to create a loop

- Correction of erosion problems associated with unauthorized trails, steep trails, old roads, and unauthorized mountain biking (mountain bikes are not allowed in the Natural Reserve)

- Proper management of the wildland-urban interface in the Bowden Ranch area for fire protection

\section{Reservoir Canyon Trailhead Issues}

Problems at this trailhead include:

- Multiple creek crossings without proper bridges, as well as maintenance needed for the Cal Poly Bridge

- Cattle on the property

- Illegal collection of mushrooms

- Lack of a holistic vision the trailhead and vicinity

- Outdated and inadequate signage (Newer signage in the City's other open spaces includes trail maps and information panels.)

\section{Sensitive Species}

There are several sensitive plants and wildflowers in Reservoir Canyon, such as mariposa lilies, owl's clover, and spineflowers. Some of these are serpentine dependent and are therefore rare. Also sensitive in general is the pristine grassland habitat on the south ridge. The region is the southern boundary for a large mammal migratory corridor, steelhead trout descendents (i.e. rainbow trout), and California redlegged frogs. A 2002 report by Cal Poly student Ben Carter indicated the presence of the endangered Chorro Creek Bog Thistle.

\section{Utility Easement Issues}

PG\&E holds maintenance easements for access to its five power line towers on the property. Two of these are scheduled for consolidation as part of the company's project to replace the 70keV 
transmission line from Atascadero to San Luis Obispo. PG\&E has acted to minimize environmental impacts with innovations such as hand digging culverts for replacement towers and using helicopters to fly in crew and materials.

\section{Legal Issues}

Three legal concerns affect the Reservoir Canyon Natural Reserve. The first is PG\&E's easement for right of access for maintenance of its transmission line. The second is a water right: A Bowden Ranch neighbor holds legal rights to one-half of the natural flow from a spring. Finally, the City holds an easement for "road purposes" across a 40-acre property in Reservoir Canyon as part of its purchase of the Hastings property.

\section{Views and Signage}

Photos were shown of views from Reservoir Canyon, trailhead signs, and of the Cal Poly Bridge.

\section{Environmental Review}

Environmental review will be undertaken as part of the conservation plan process. Environmental issues include potential for impacts to rare or endangered plant and animal species, potential for erosion problems from new or existing trails, and potential for exposure by trail volunteers and users to naturally occurring asbestos (NOA) due to the exposed serpentine rock in Reservoir Canyon.

\section{Conservation Planning Process}

Overall, the planning process includes several major steps. The first is background documentation research, which is ongoing. The second step is this public meeting. Third will be preparation of a draft conservation plan. The draft plan will then be presented to the Planning Commission and Parks and Recreation Commission to receive feedback from the commissions and the public. Finally, the revised draft plan, integrating all feedback, will be presented to the City Council for final document approval.

\section{Public Comments and Q\&A}

The following are comments and questions made by the public during the meeting. The City's responses--given at the meeting--were made by Freddy Otte (City Biologist), and Neil Havlik (Natural Resources Manager).

Comment: Cattle from the adjacent private property are locked in the area near the Reservoir Canyon trailhead for about 65 days out of the year.

Question: Why are there no "no smoking" signs among the trailhead signs?

City Response: Although this is covered under the "no fires" rule posted on the signs, we will consider adding no smoking signs, particularly in light of San Luis Obispo's recent (2010) ban on public smoking.

Question: Have you considered adding public toilets to the open space?

City Response: This is a double-edged sword: While they might prevent urination in the natural habitat, they are also expensive and difficult to maintain. Additionally, the City has generally discouraged structures and garbage cans, as they tend to attract animals. The philosophy has been "pack it in, pack it out."

Question: Has there been any archaeological work done in the area?

City Response: Nothing has been found so far, except for historical resources such as structures from when the property was an active reservoir.

Question: Are there any special rights associated with the property?

City Response: There are no mineral rights, or etc. The property has the restriction by City mandate that it be maintained as an open space.

Question: What about water rights? There may have been something about using enough water for 40 head of sheep. 
City Response: The City is unaware of such a right, but will investigate. [City will contact Utilities Department about the deed.]

Question: Can the City look into removing the trail from the Sheffer property?

City Response: The City will consider it depending on best trail management practices, but the City has a legal easement for "road purposes" on the property.

Question: What about signs indicating the trail is entering private property?

City Response: The City will consider this option.

Comment: There should be more investigation about the actual need to complete a loop trail. Cutting a road/trail ruins the visual aspects of the canyon-you can see the trail from far away.

City Response: Evidence and observation have shown that people are completing a loop on their own already. It is difficult to stop this behavior once it has begun, and adding a trail would make it safer than the current steep areas down the north side of the where people traverse to go back to the Reservoir Canyon trailhead. Nevertheless, the City will take this and the potential for environmental harm into account when investigating whether to complete a loop trail system.

Question: What about adding a sign to prevent people from going off trail?

City Response: Signs might help, but mountain bike tracks on the property show that signs are often ignored.

Comment: Conservation should emphasize native aquatic species and aim for a fully functional ecosystem. The area of protection should be maximized.

City Response: Maps in the conservation plan document will clearly show which are the protected areas and which are the management areas. Essentially, management will be limited to the trails and a small amount of space on either side of the trail. The rest will be protected as natural habitat.

Comment: Please continue the no-bike policy at Bowden Ranch. The area is too steep and biking causes too much erosion.

Comment: Clarify the grazing policy for the area.

Comment and Question: Clarify the fire management program. There should be coordination with CalFire and other agencies. Also: should there be a "let it burn" policy for some parts of the property?

City Response: The Conservation Plan will address fire management through a Fire Protection Plan. It will include guidance that preserves the structure of the hillside, such as an avoidance of bulldozing when something like airdropped fire retardant would do.

END

Recorded by:

Brian Provenzale

Natural Resources planning intern 


\section{Appendix G: Initial Photo-Monitoring Points}

As discussed in Section 4.3 of this plan, these are the proposed initial photo-monitoring points for RCNR. These locations may be modified - or new locations may be added - as conditions warrant.

\section{Beginning from the Reservoir Canyon (i.e. north) entrance of RCNR:}

1. The Reservoir Canyon trailhead

2. The waterfall area near the trailhead
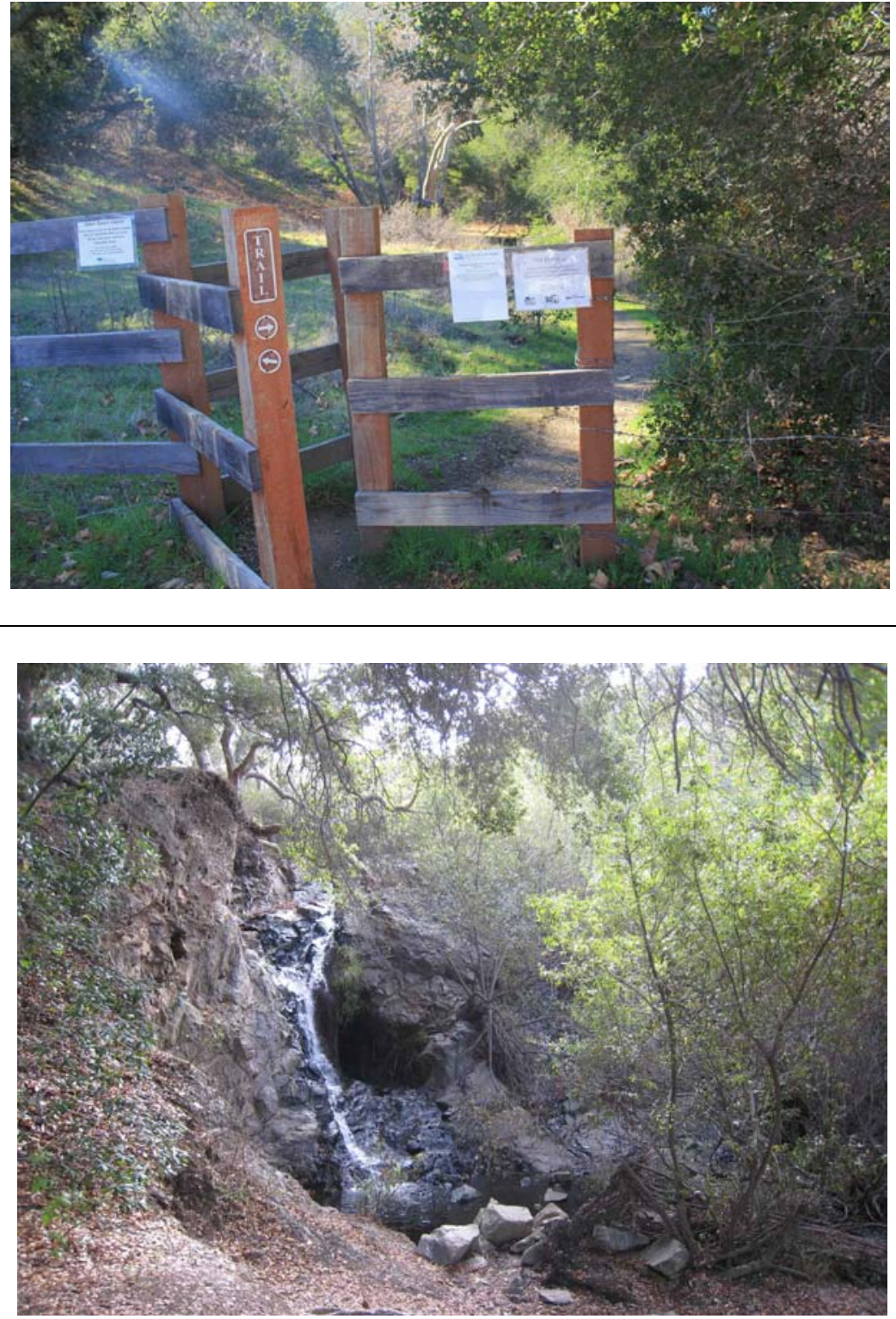
3. Initial creek crossings (two locations)

$-3 a$.

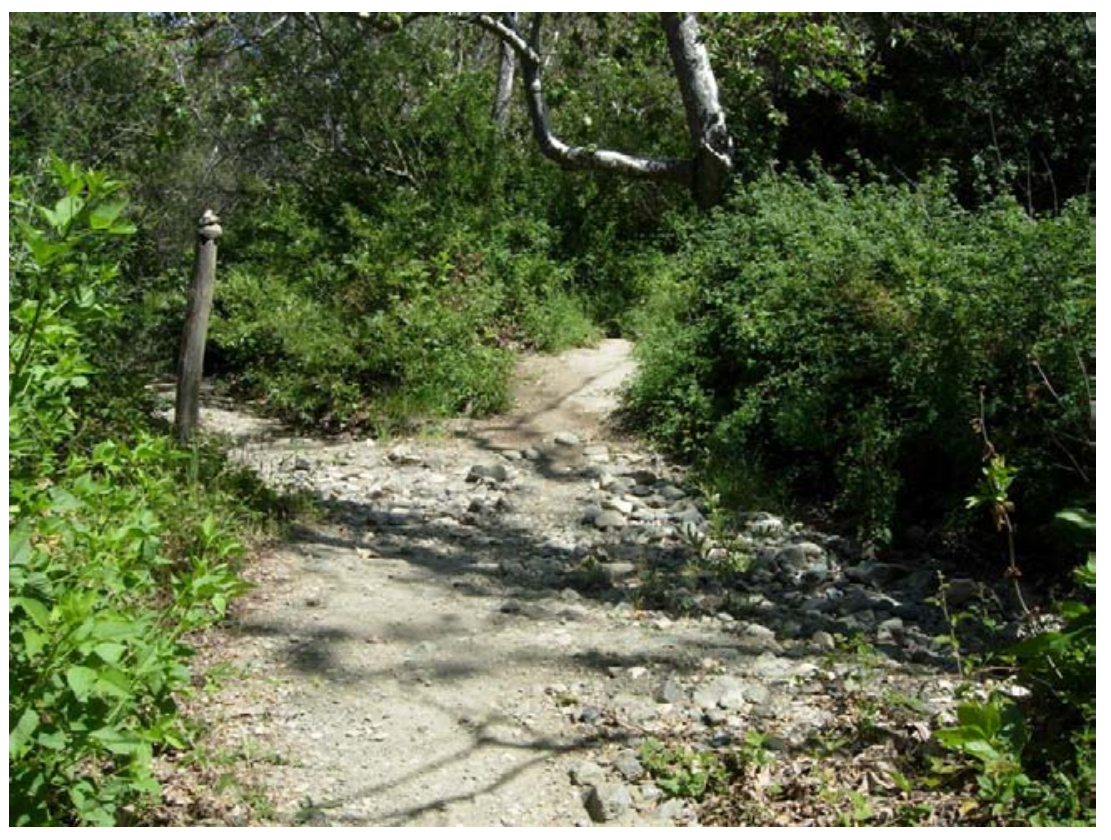

$-3 b$.

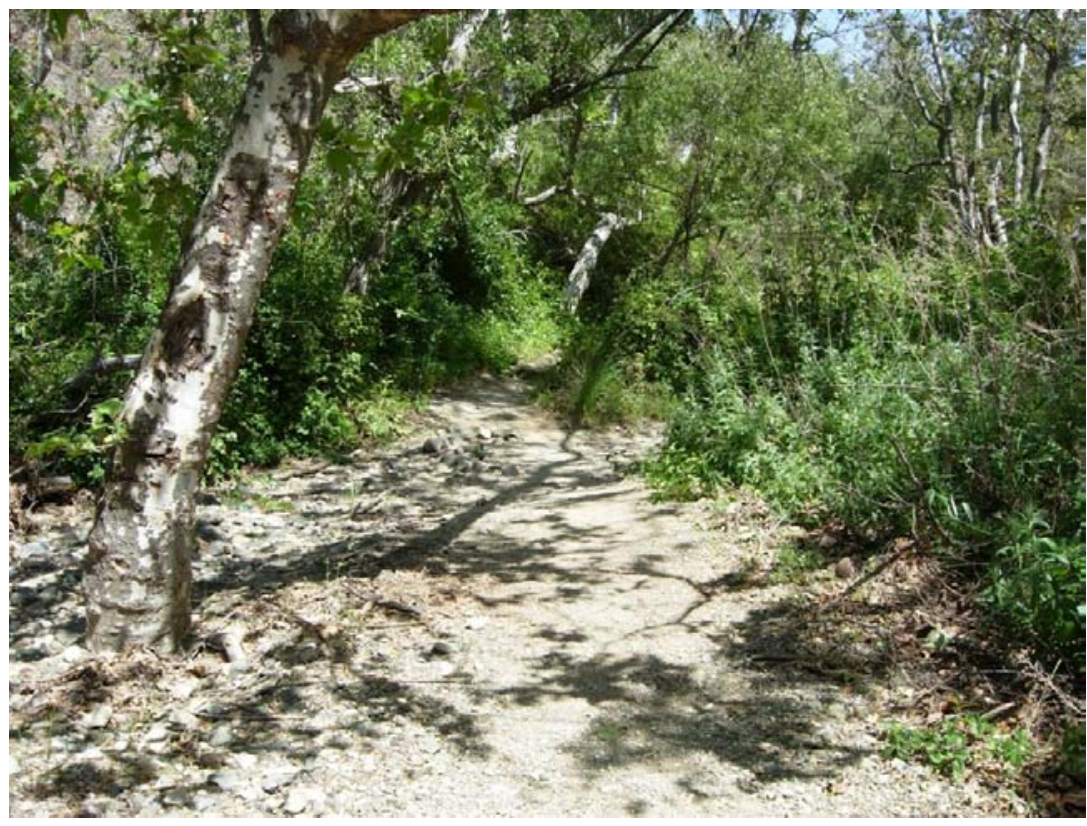




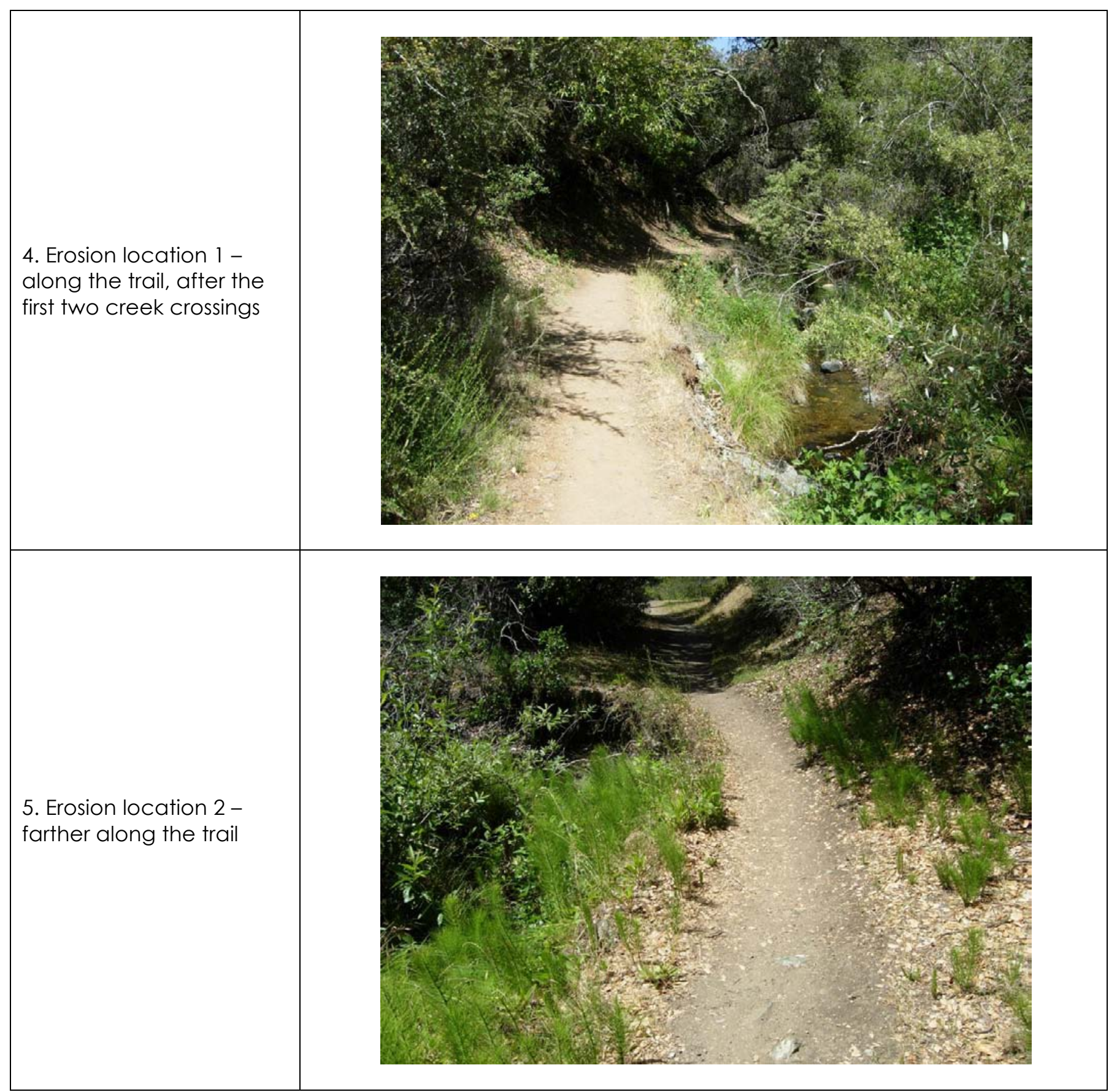


6. Upper creek crossing final creek crossing before ascending the trail up the ridge
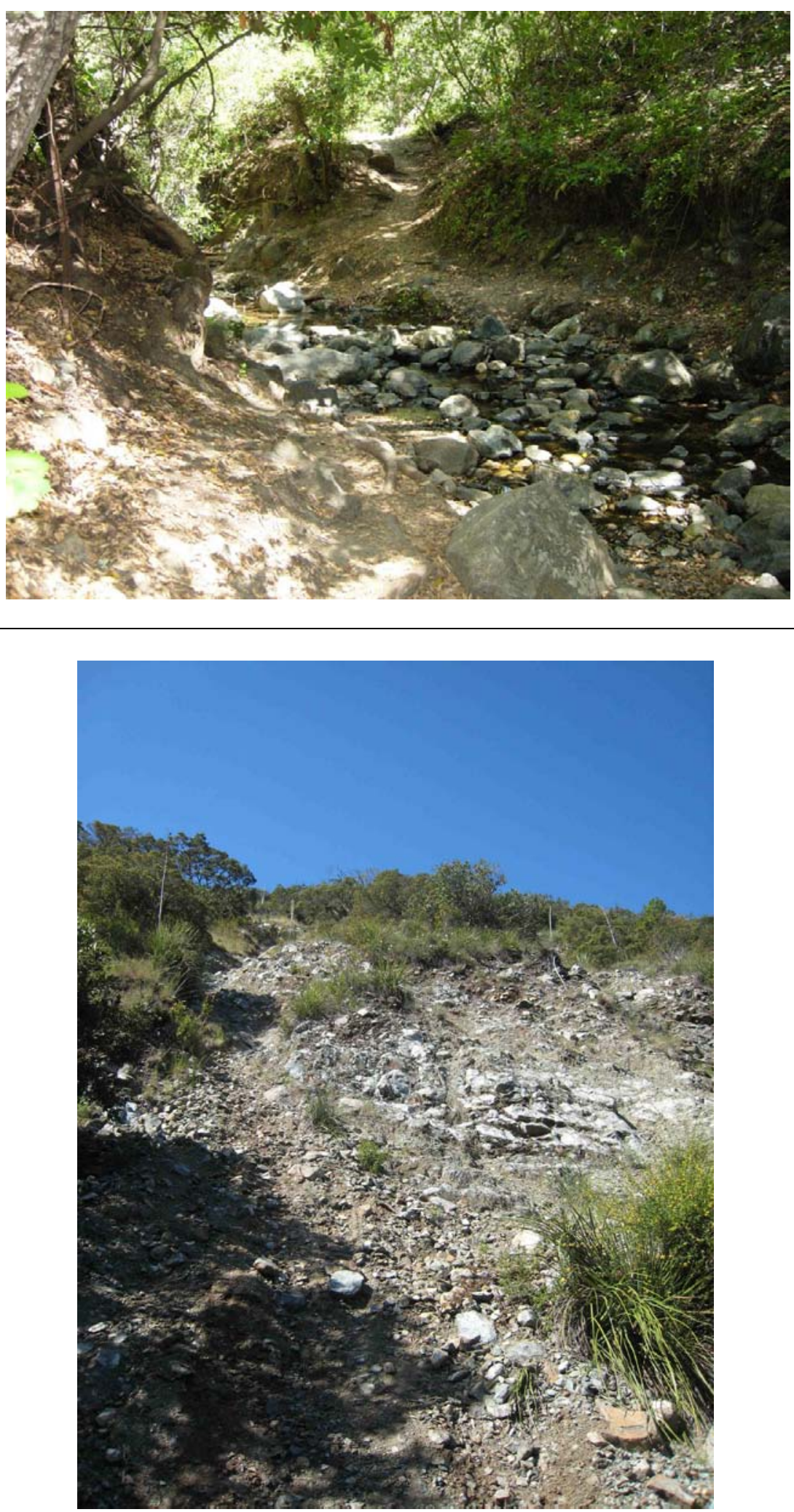

7. Erosional gully along the trail, after the final creek crossing.

- 7a. Facing up the ridge 


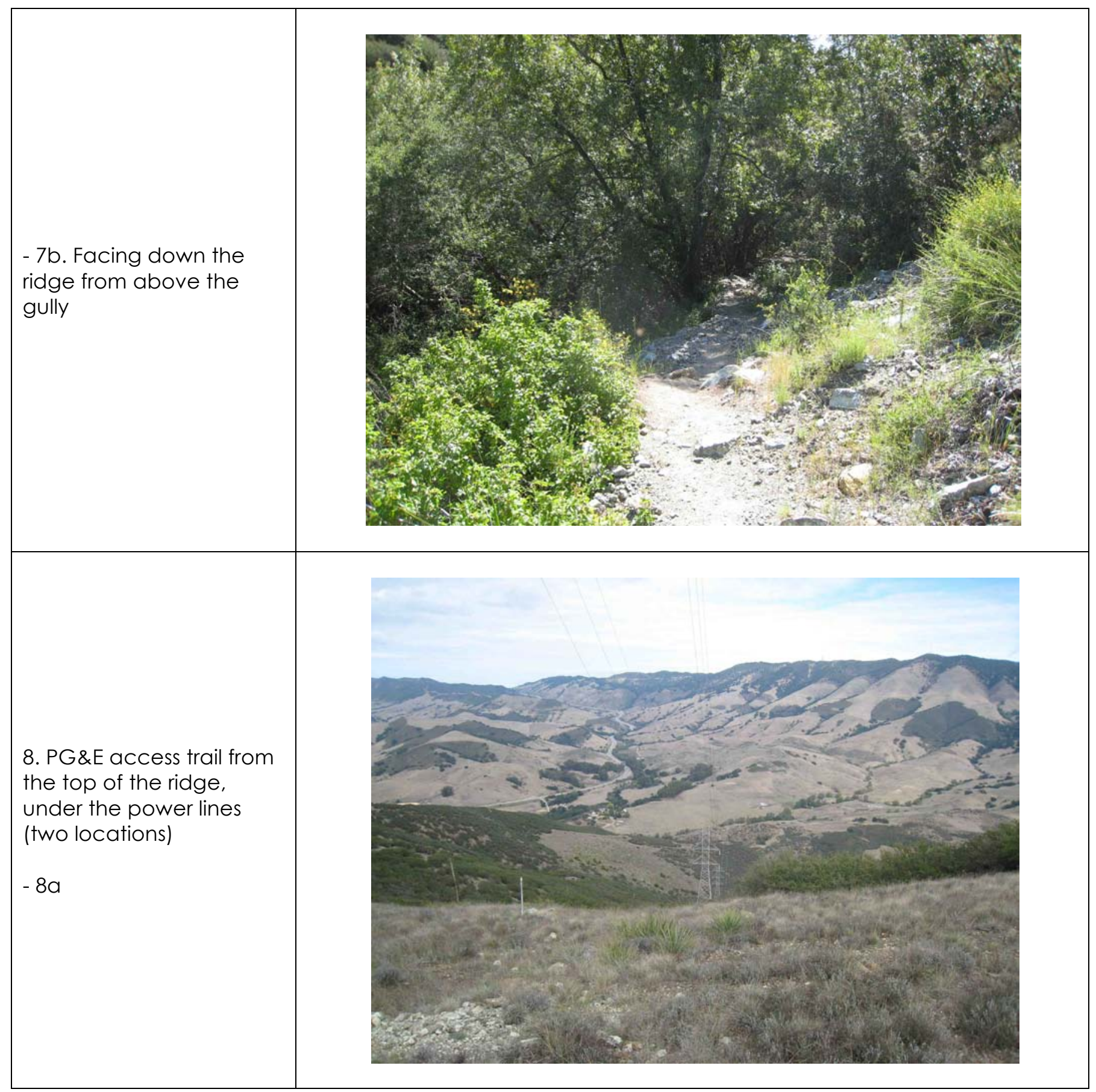




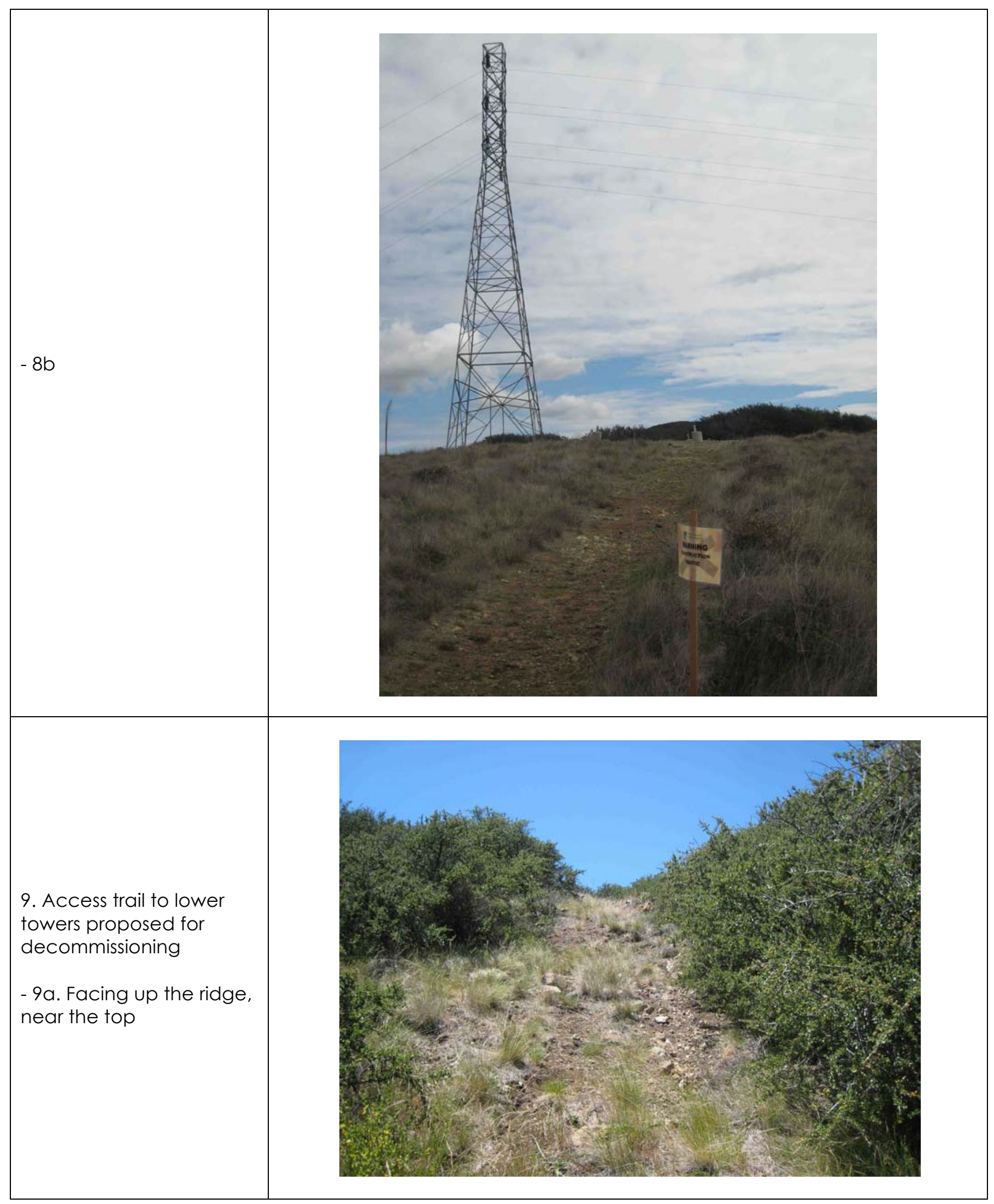


- $9 \mathrm{~b}$. Facing up the ridge, about $1 / 2$ of the way down the trail
- 9c. Facing down the ridge, about $1 / 2$ of the way down the trail. (Proposed heli-spot would be to the left of the electrical tower seen in the center of the image.
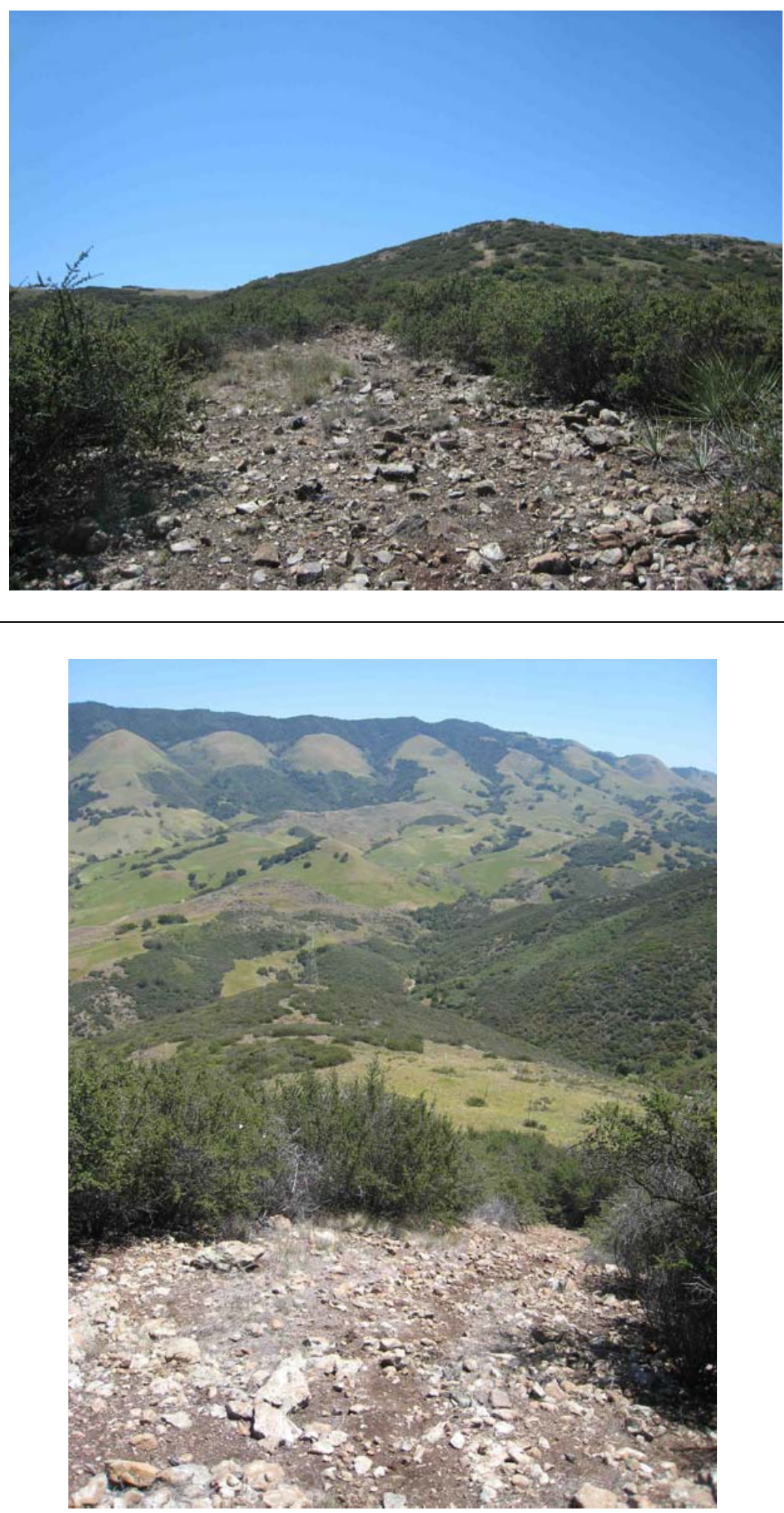
10. Proposed heli-spot for PG\&E maintenance access

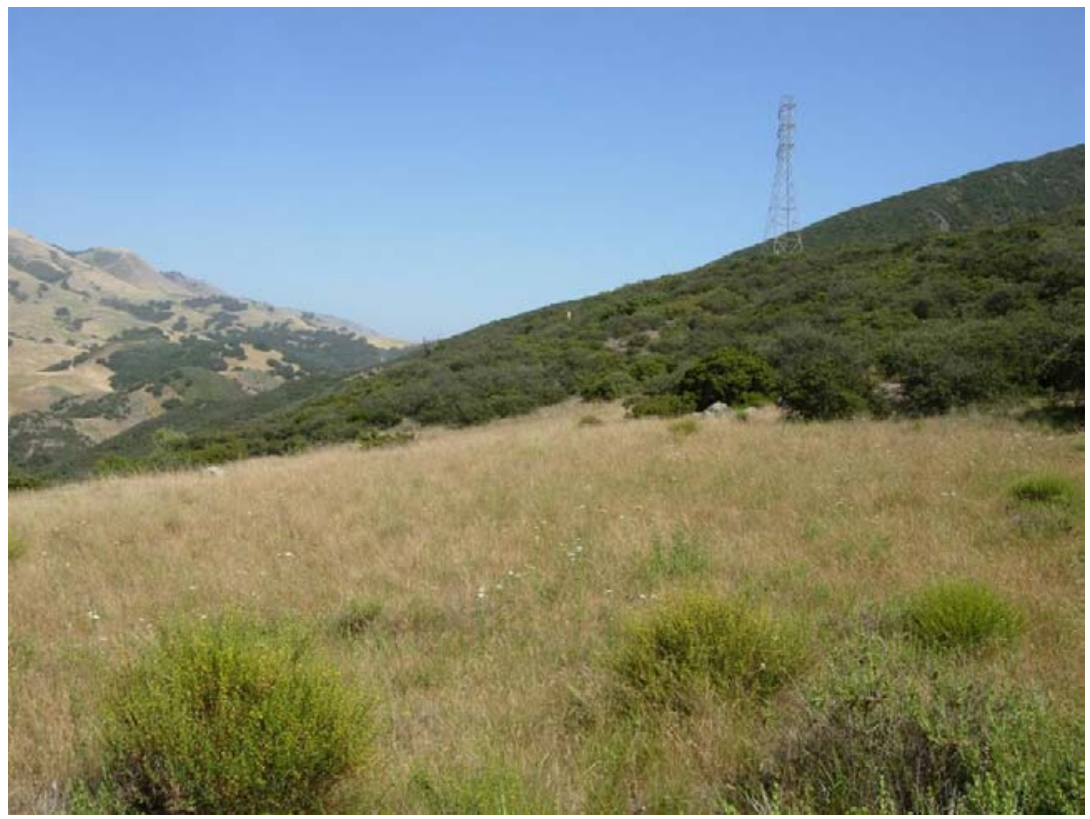

Beginning from the Bowden Ranch (i.e. west) entrance to RCNR on Lizzie Street:

11. The Bowden Ranch trailhead

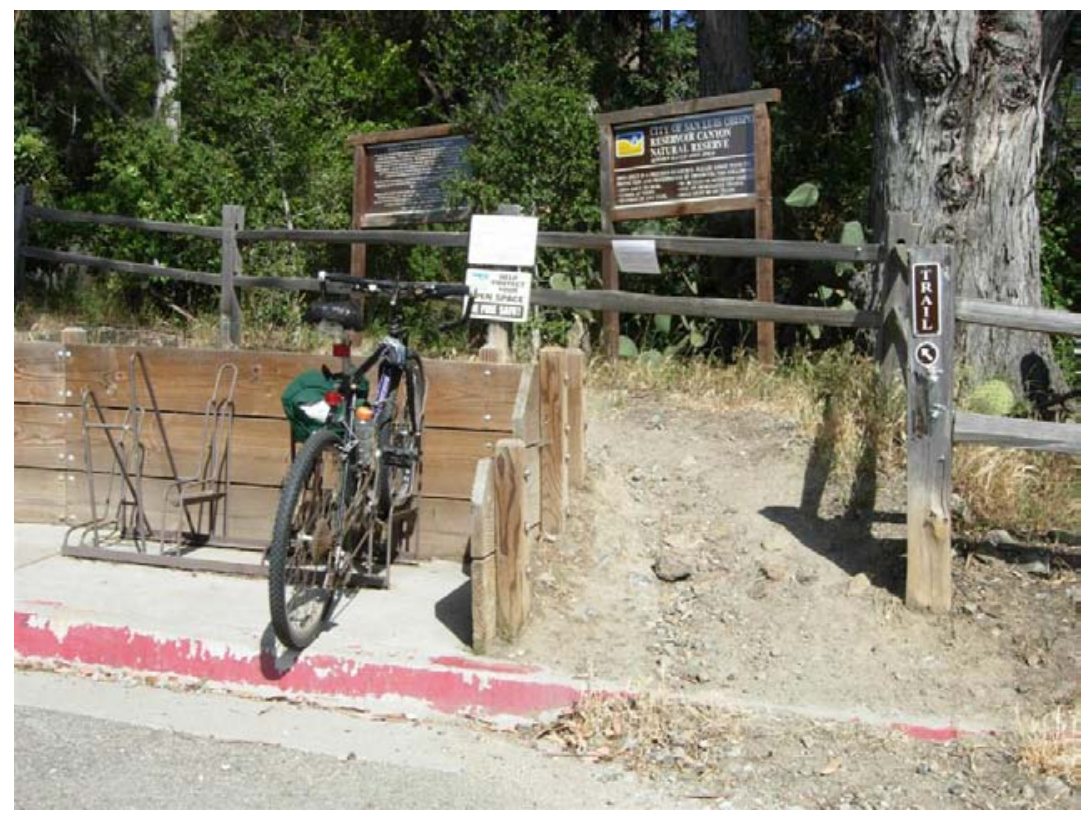




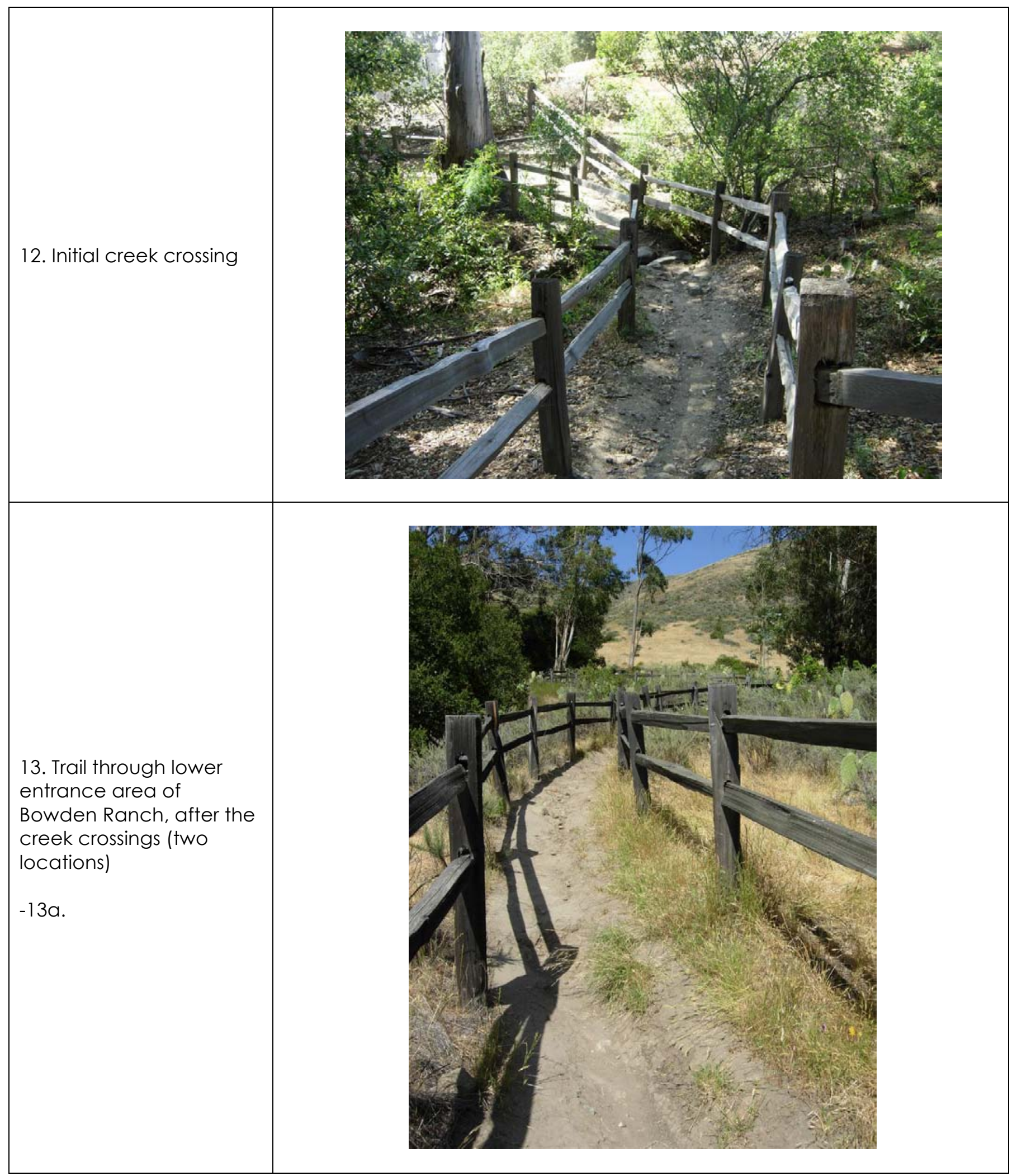




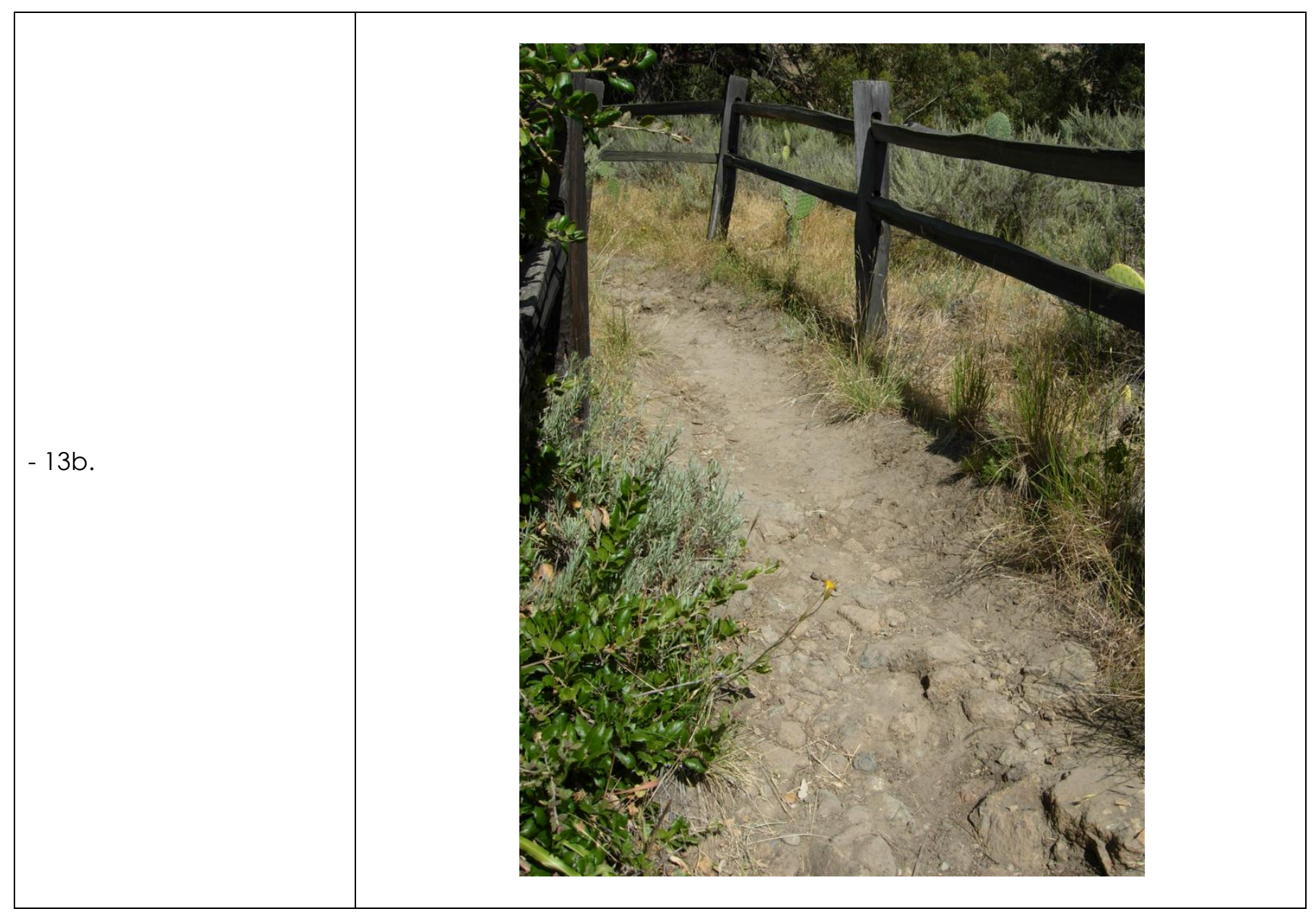




\section{Appendix H: Wildfire Jurisdictional Responsibility Areas in RCNR}

The map below shows the state and local responsibility areas for Reservoir Canyon Natural Reserve.

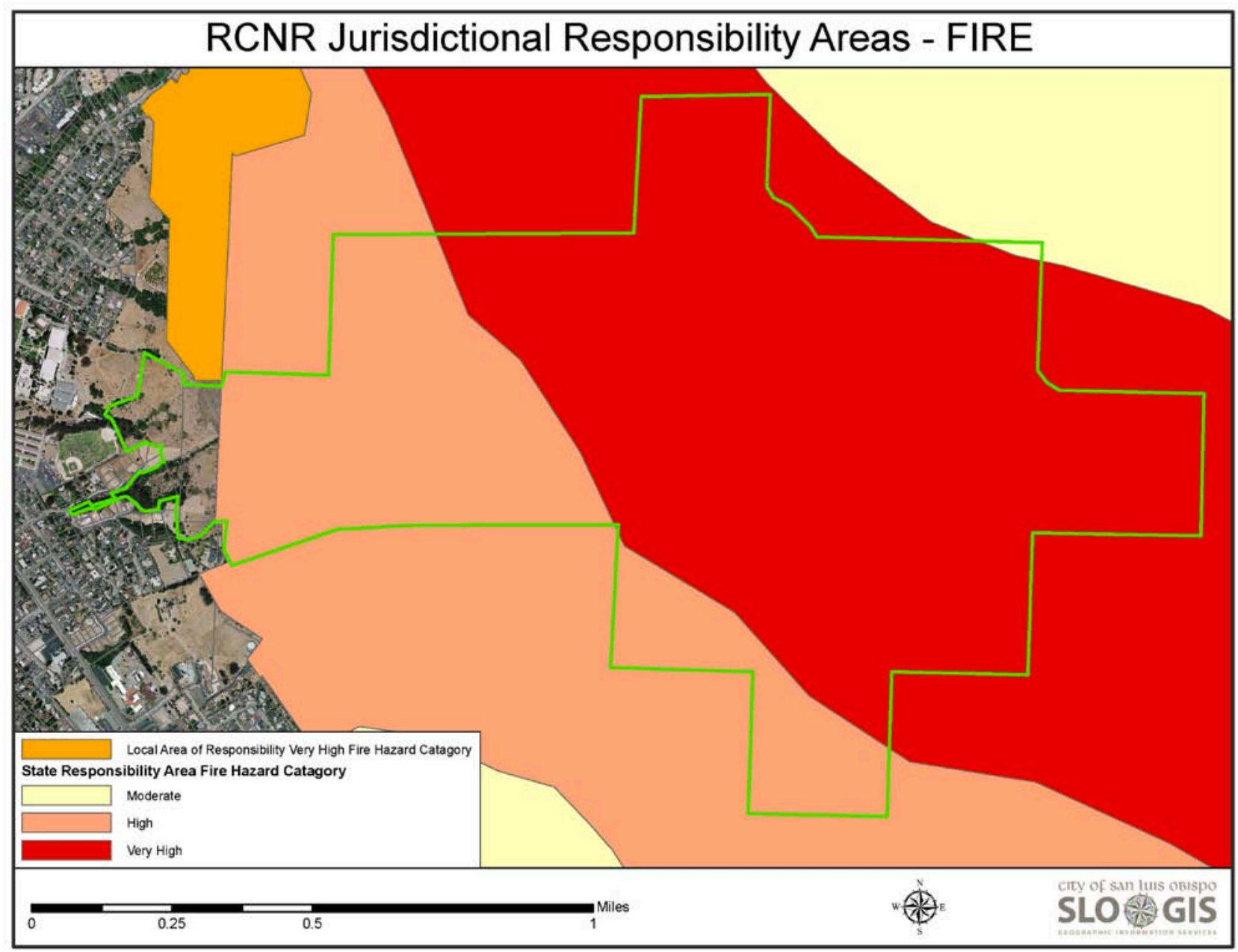

Figure APP 2: Wildfire Jurisdictional Responsibility Areas in RCNR 


\section{APPENDIX I:}

An Archaeological Surface Survey for Existing Trails

\& Proposed Trail Extension at the Reservoir Canyon Area,

San Luis Obispo, San Luis Obispo County, California

Prepared for:

The City of San Luis Obispo

Natural Resources Manager

990 Palm Street

San Luis Obispo, CA 93401

Prepared by:

Thor Conway

Heritage Discoveries Inc.

836 Mission Street

San Luis Obispo, CA 93405

May 25, 2012 


\section{Summary of Findings}

The City of San Luis Obispo is preparing a planning document including existing trails and an extension for a new trail in the Bowden Ranch and Reservoir Canyon areas in the City of San Luis Obispo. This study includes a Phase I cultural resources survey and literature review with planning recommendations. Records searches indicate several previous cultural resource studies adjacent to the study area with mainly negative results. The present cultural resources survey gave negative results for the trail network.

Recommendations are given that no further cultural resource studies should be required for the existing trails and proposed trail extension into Reservoir Canyon. Other parts of the ridge top may require future archaeological surface surveys if further developments take place. The poor surface visibility off of the trail areas yielded inconclusive results for cultural resources in these other areas. 


\section{Table of Contents}

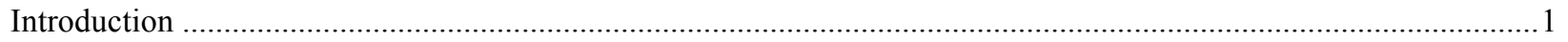

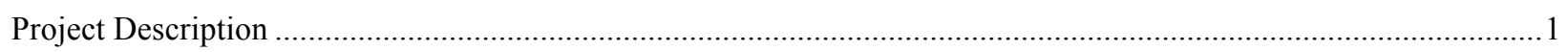

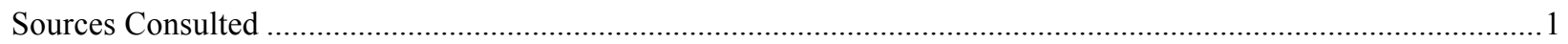

Archaeological Studies in the Project Vicinity .........................................................................................................

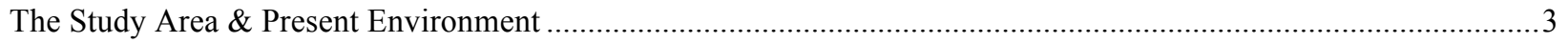

Ethnography

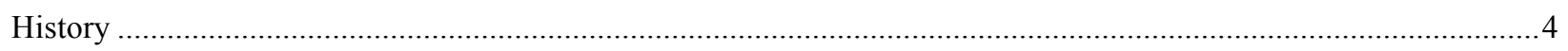

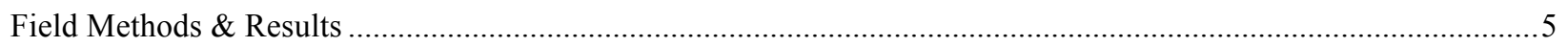

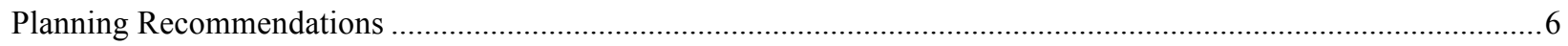

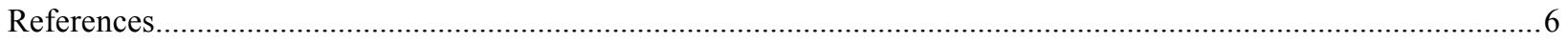

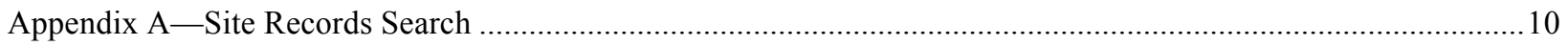

\section{List of Figures}

Figure 1-The archaeological survey area marked with a red line from Reservoir Canyon to Bowden Ranch in the City of San Luis Obispo (San Luis Obispo Quad.)..........................

Figure 2 -The archaeological survey area of the existing trail system.............................

Figure 3-The archaeological survey area for the proposed new trail system........................6 


\section{Introduction}

This report describes an archaeological surface survey completed in May 2012 for the City of San Luis Obispo at the Reservoir Canyon and Bowden Ranch areas in San Luis Obispo, San Luis Obispo County (Figure 1). The study, done in response to background planning requirements, was completed to determine whether prehistoric or historic era cultural resources occurred within the existing and new trail areas. Neil Havlik, Natural Resources Manager for the City of San Luis Obispo, provided background information and project maps.

Thor Conway, Heritage Discoveries Inc. of San Luis Obispo, California, completed the study. Thor Conway has forty years archaeological experience across North America including twenty years in California.

\section{Project Description}

This report describes an archaeological surface survey completed as part of the expanding trail system in the in the City of San Luis Obispo (Figure 1). The study area includes corridors situated in the foothills and mountain between Bowden Ranch and Reservoir Canyon.

\section{Sources Consulted}

A search was made for pertinent background information relating to prehistoric and historic land use in the project area. An archaeological sites record search from the Central Coast Information Center of the California Historical Resources Information System at the University of California at Santa Barbara included recorded archaeological sites and surveys within a one-half mile radius of the study area (Appendix A). The results showed that the specific study area had not been subject to a previous archaeological survey, but archaeological work has occurred on adjoining properties.

\section{Archaeological Studies in the Project Vicinity}

Previous archaeological investigations near the study area include twelve recorded archaeological sites, two isolated finds and numerous cultural resource studies. No cultural resources were found in several surveys (Hoover 1971; Parker 1999). A corridor just north of the study area also did not contain cultural resources (ERCE 1991a \& b). 


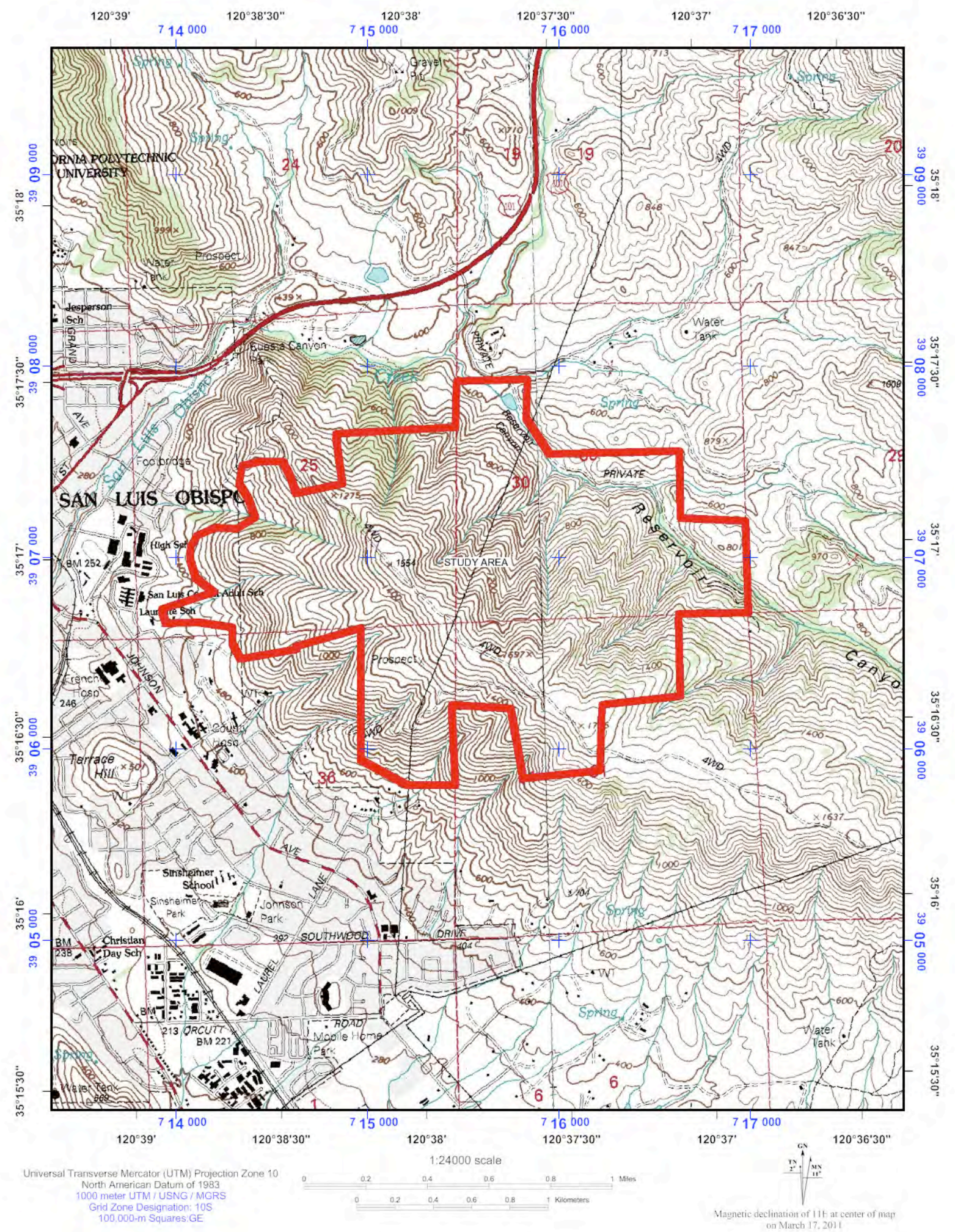

Figure 1-The archaeological survey area marked with a red line from Reservoir Canyon to Bowden Ranch in the City of San Luis Obispo (San Luis Obispo Quad.). 
An historic era site, CA-SLO-1082H was located just west of the study area (Gibson 2000).

\section{The Study Area \& Present Environment}

The present study area is located in the foothills and mountains at the northern edge of San Luis Obispo and east of Highway 101. The project area includes a prominent hill "Tower Hill," a portion of Reservoir Canyon, the southern side of hill and foothills (Figure 1). Over $80 \%$ of the study area has very steep terrain not suited for settlement.

The study area lies in a region with a mixture of open grasslands and chaparral supporting diffuse oaks, poison oak and other plants. Vegetation in and adjacent to the study area also includes various grasses and seasonal plants.

\section{Ethnography}

The entire San Luis Obispo area, including all of the project area, was home to the Northern Chumash, or Obispeno, for over 9,000 years. The Obispeno territory covered an area from Arroyo Grande Creek to San Simeon along the coast with inland settlements across the Coastal Range and into the Salinas River drainage north of Paso Robles (Gibson 1983; King 1984). The Northern Chumash world bordered upon the Yokuts of the Central Valley in the area now defined as eastern San Luis Obispo County, while their neighbors to the north were the Salinans. South of Arroyo Grande, related Chumash groups, such as the Purisimeno and inland the Cuyama Chumash, were settled. The Chumash made use of several ecological settings including coastal resources, oak openings in the valleys, foothill areas and extensive grasslands.

The Chumash language family is composed of six languages that are part of the larger Hokan division of Native American languages (Grant 1978). Their distinctive language and geographic setting held define the Obispeno Chumash whose name was taken from the first Spanish mission located in their territory-Mission San Luis Obispo de Tolosa. Numerous historic Obispeno villages have been identified from mission records and informant interviews. The Obispeno area showed a somewhat dispersed settlement pattern as compared to the intensive settlement and larger village sizes found along the Santa Barbara Channel (King 1984).

The earliest recorded visit to an Obispeno village took place in 1595 when the Spanish sailed into San Luis Obispo Bay under the command of Cermeno. He anchored in front of the premiere village named Sepjato which was located at the mouth of San Luis Obispo Creek on the hill now occupied by the San Luis Bay Inn. The Spanish account noted that these Indians “... are fishermen and there is fish and some 
shell-fish with which they sustain themselves"- a statement which applied to the descendants of this village who resided at the San Luis Obispo mission two hundred years later (Wagner, 1929: 161).

By the time of the Spanish expansion into California at the end of the 1700's, Chief Buchon lived at Sepjato and held the status of a grand-chief leader of several villages in the greater San Luis Obispo area from Avila to Pismo Beach to Morro Bay.

The area that became the community San Luis Obispo re-entered the historic era on September 1st, 1772 when the first mission was founded beside San Luis Obispo Creek. This first mission within Chumash territory gradually expanded in size and importance. In its first decade, some Obispeno Chumash were dissatisfied with the mission and attempted to burn it down (Kocher 1972). The influence of the mission increased in the 1780's when Pedro Fages reported that the Indians at the San Luis Obispo mission "...have readily adapted themselves to what it was sought to teach them" (Englehardt 1933: 39). Judging from the mission records listing the number of Indians recruited by this mission, in 1803 most of the numerous Obispeno Chumash groups had moved away from their traditional villages to the vicinity of the mission (King 1984: 14).

\section{History}

The cultural heritage of San Luis Obispo started several thousand years ago when the first Chumash settled along the streams and foothills that now lie within the community. The city's rich cultural heritage extends from the prehistoric era, when the Chumash were the sole inhabitants, to the historic period in the late 1700's when Spanish and Mexican influences greatly changed the aboriginal way of life. After the decline of the mission era in the 1830's, San Luis Obispo gradually grew into a thriving town. For a period of over sixty years, a large population of Chinese immigrants lived in a busy Chinatown. The arrival of the railroad accelerated the growth of the commercial and residential community that included many Americans from the mid-West and further east.

In the 1869's, the economy of San Luis Obispo changed from a cattle market based on hides and beef to a mixed economy including dairy operations introduced by Swiss-Italian farmers. In the mid- $20^{\text {th }}$ century agricultural development continued to diversify with more grain production (Krieger 1988). The community of San Luis Obispo also changed in 1903 when the California Polytechnic State University was opened. 
Historians have studied the growth and development of San Luis Obispo (Angel 1883; Krieger 1988). In addition, local histories link the economic development of San Luis Obispo and the importance of the Southern Pacific Railway in the expansion of the community and California (Best 1964; Nicholson 1980; Wilson \& Taylor 1952).

\section{Field Methods \& Results}

An archaeological surface survey was made by Thor Conway at the proposed trail extension study area in April 2012 by walking the trails and proposed trails in project area at two meter intervals (Figures $1,2 \& 3)$. The area surveyed for cultural resources was generally overgrown with field grasses on steeply sloped hillsides. Cultural remains were not located during the survey. The visibility for the trails and proposed trails was $80 \%$; but visibility in other areas was poor with $20 \%$ or less surface exposures.

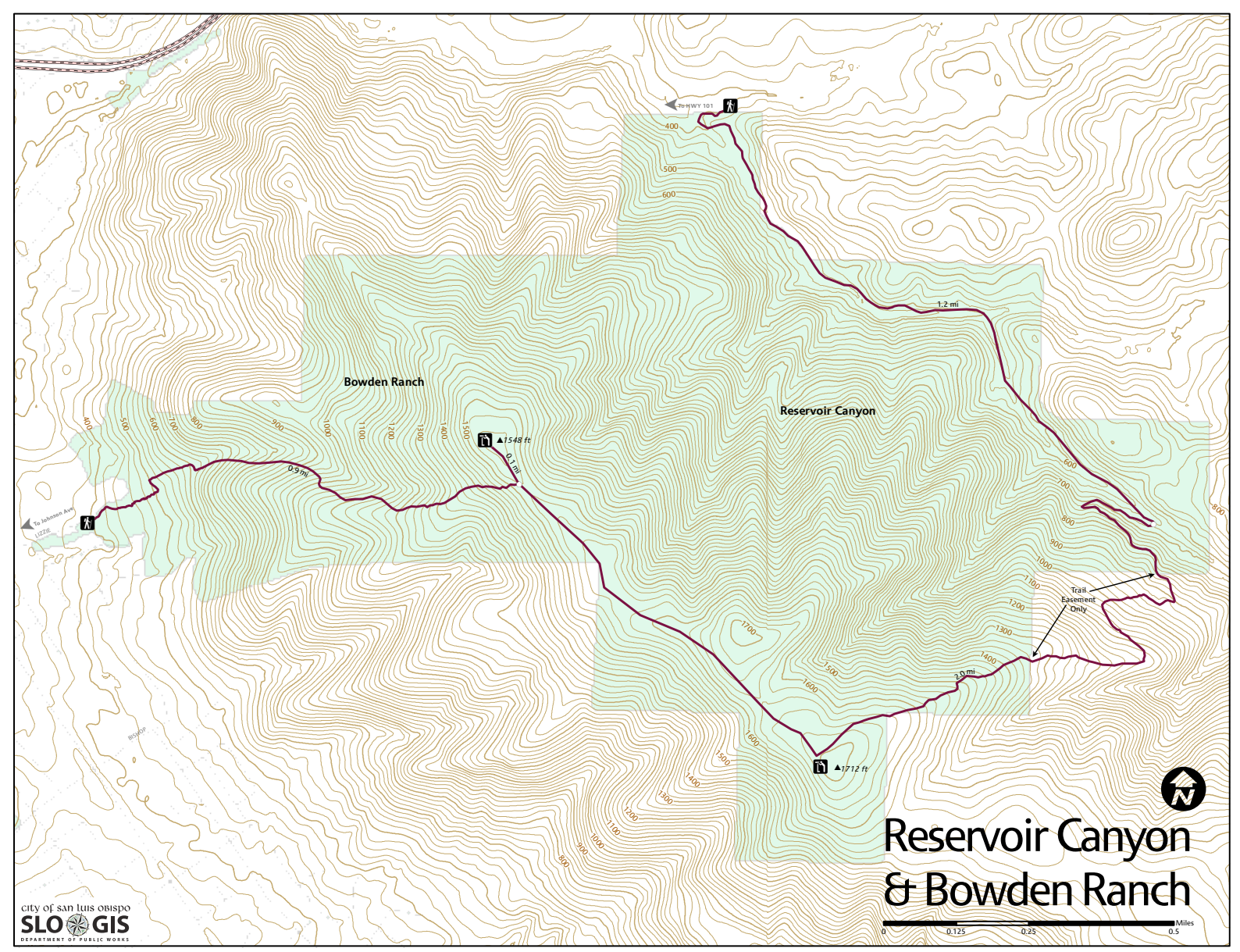

Figure 2-The archaeological survey area of the existing trail system. 


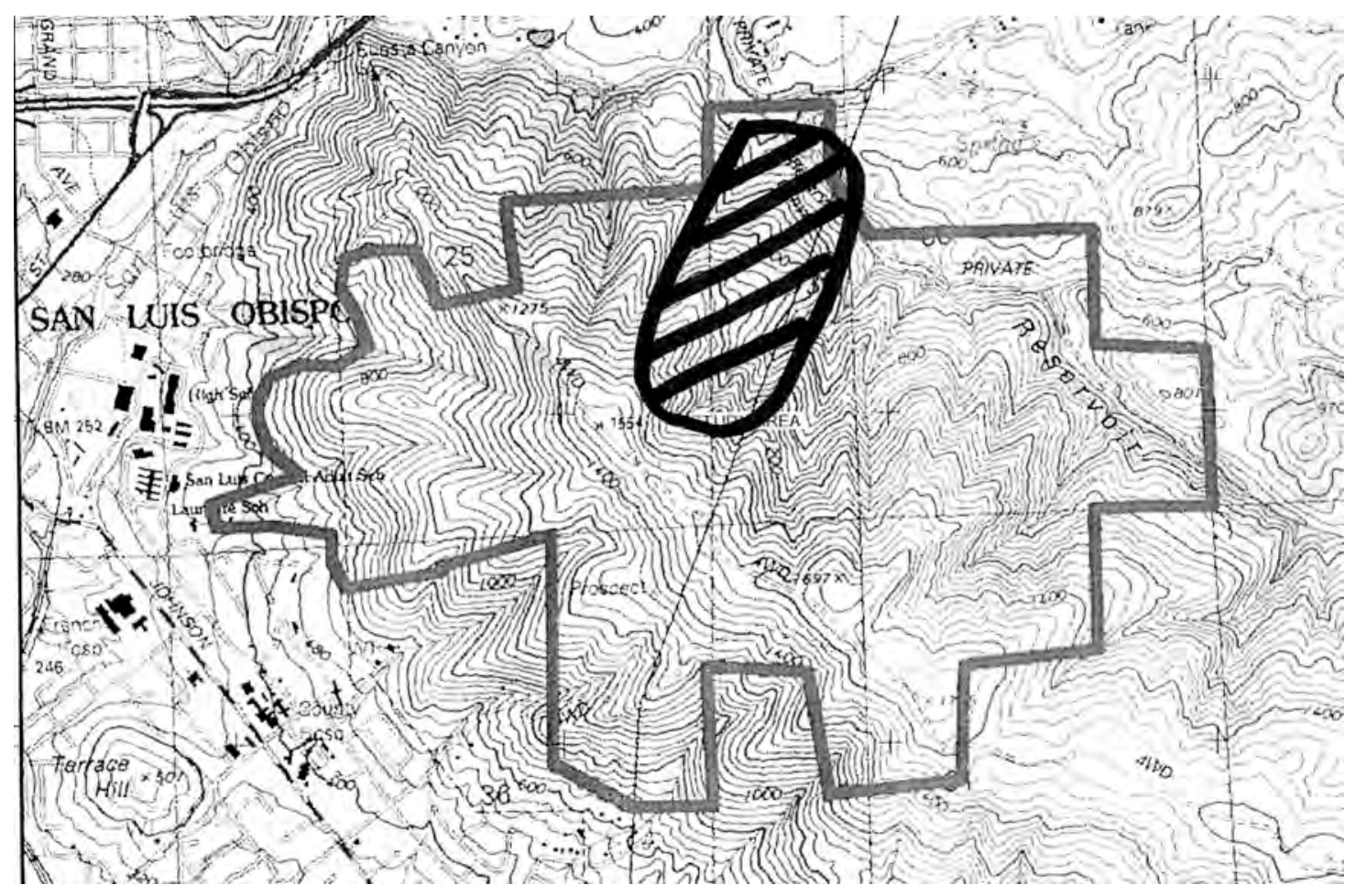

Figure 3-The archaeological survey area (hatched) for the proposed new trail system.

\section{Planning Recommendations}

It is recommended that no further archaeological studies should be required for the existing and new trail systems based on the negative results of the present surface survey.

It also is recommended that other parts of the ridge top may require future archaeological surface surveys if further developments take place. The poor surface visibility off of the trail areas yielded inconclusive results for cultural resources in these other areas.

\section{References}

Angel, Myron

1883 History of San Luis Obispo County, California. Reprinted 1966 by Howell-North Books Berkeley from the original Thompson \& West. Oakland.

Bertrando, Betsy

1998 Historical Significance Evaluation for Sunny Acres, San Luis Obispo County, CA. On file, Central Coast Information Center, UCSB. Santa Barbara. 
Carbone, L.

2003 A Phase I Archaeological Resources Assessment for a Proposed Verizon Cellular Site, 2230 Flora Street,

City and County of San Luis Obispo, California. On file, Central Coast Information Center, UCSB. Santa Barbara.

Conway, Thor

1995 An Archaeological Investigation of Historic San Luis Obispo, California (The Kozak Parking Lot Project).

City of San Luis Obispo Public Works Dept. San Luis Obispo.

1996 Phase I Archaeological Survey of 770 Palm Street, San Luis Obispo, California. Central Coast Information Center. Santa Barbara.

1997 Phase II Archaeological Testing of a Mission Era Midden at 770 Palm St., San Luis Obispo, California. Central Coast Information Center. Santa Barbara.

2000 Phase I Archaeological Survey of the South Higuera Street Bridge Seismic Retrofit Project, San Luis Obispo County, California. Report on file, Central Coast Information Center. Santa Barbara.

2001a A Phase I Archaeological Surface Survey of the Historic Foreman / DeVaul Ranch, Los Osos Valley Road, San Luis Obispo, California. Report for WestPac Investments. San Luis Obispo.

2010 An Archaeological Survey for a Proposed Trail at the Irish Hills Nature Reserve, San Luis Obispo, San Luis Obispo County, California. Prepared for the City of San Luis Obispo by Heritage Discoveries Inc. San Luis Obispo.

Cooper, De Guy

1875 Resources of San Luis Obispo County, California. Bacon \& Company. San Francisco. Reprinted in A Vast

Pastoral Domain, The Library Associates, Cal Poly State University. San Luis Obispo.

Dart, Louisiana Clayton

1978 Vignettes of History in San Luis Obispo County. Privately Published. San Luis Obispo.

Engelhardt, Zephyrin

1933 Mission San Luis Obispo in the Valley of the Bears. Franciscan Fathers of California. Santa Barbara.

ERCE

1991a Draft Environmental Impact Report State Water Project Coastal Branch (Phase II) Local Distribution Lines and Facilities. On file, Central Coast Information Center, UCSB. Santa Barbara. 
Parker, John.

1996 Cultural Resource Investigation of the Wolf-Adamski Parcel APN 002-325-015 Lizzie St., San Luis Obispo. On file, Central Coast Information Center, UCSB. Santa Barbara.

1997 Archaeological Monitoring of the Wolf-Adamski Parcel APN 002-325-015 Lizzie Street. On file, Central Coast Information Center, UCSB. Santa Barbara.

1999 Cultural Resource Investigation of the Proposed Andrews/Conejo Storm Drainage System. On file, Central Coast Information Center, UCSB. Santa Barbara.

Wagner, Henry

1929 Spanish Voyages to the Northwest California Coast in the Sixteenth Century. California Historical Society. San Francisco. 


\section{CENTRAL COAST INFORMATION CENTER}
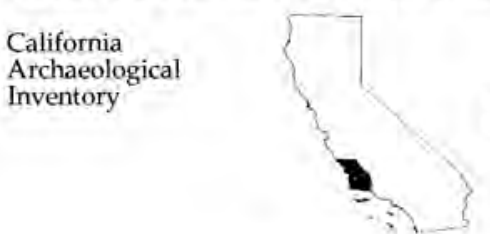

SAN LUIS OBISPOAND SANTA BARBARA COUNTIES
Department of Anthropology

University of California, Santa Barbara

Santa Barbara, CA 93106-3210

(805) $893-2474$

FAX (805) 893-8707

Email: centralcoastinfoøgmail.com

April 11, 2012

Thor Conway

Heritage Discoveries

838 Mission Street

San Luis Obispo, CA 93405

Dear Mr. Conway,

Enclosed are the results of the record search you requested for the San Luis Obispo Park Project. Our records were searched for all archaeological sites, historic resources, and previous cultural resource surveys within a two mile radius of the project area.

In this search, three archaeological site(s) and fourteen cultural resource survey(s) were found. The survey locations were mapped onto portions of the San Luis Obispo and Lopez Mountain quad(s). A bibliography of these surveys is included. A search of the inventories for the State Historic Property Data Files, National Register of Historic Places, National Register of Determined Eligible Properties, California Historical Landmarks, California Points of Historic Interest, California OHP Archaeological Determinations of Eligibility, and the Caltrans State and Local Bridge Surveys yielded two property evaluation(s) within the search radius.

According to our records, the property has not been surveyed. Therefore a cultural resource survey is recommended.

Please contact me if you have any questions about this search.

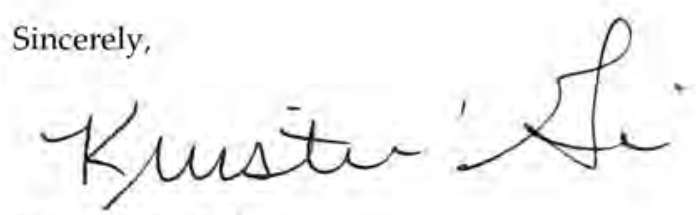

Kristina M. Gill

Assistant Coordinator 
